د. د محمد كمال سرحان سـ

\title{
المتفاعلات النصية
}

\section{في مجموعة "حكاية الليل والطريق" لطه وادي}

د - (" محمد كمال سرحان (")

المقدمة :

النص الروائي عالم سردي منفتح على عوالم متعددة؛ إنه فضاء منسع لاستيعاب العديد من الأجناس المختلفة؛ حيث يتفاعل مع كافة السياقات الخارجية المحيطة به؛ فيصير النص مجموعة من الأنساق المتجاورة، التي تتداخل في علاقات لإنتاج دلالات جديدة؛ تثري النص، وتزيد فاعليته؛ فينتج التتاص الفني، الذي يعد "أحد مميزات النص الأساسية، التي تحيل على نصوص سابقة عليها أو لأ

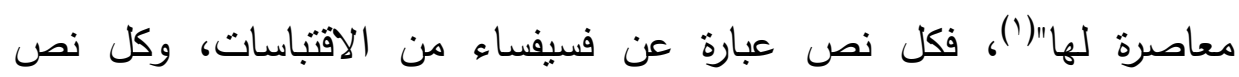
امتصاص وتحويل لنصوص أخرى. ومن هنا فإنَّ النصوص الأدبية نتاج تفاعل مع نصوص سابقة أو معاصرة؛ ومن ثنَّ فإنّ وجود هذه النصوص داخل النص الجديد ينتج عنه بالضرورة أداة تحويل في دوالها ومدلولاتها؛ وهنا تصبح لها قراءة جديدة، ومعان مختلفة داخل سياقها الحالي (؟). والتتاص مصطلح نقدي حديث وافد من الغرب؛ ظهر على يد الباحثة الفرنسية "جوليا كريستيفا"في النصف الثاني من القرن العشرين - التي "اقترحت

$$
\text { ( ) (أستاذ الأدب العربي الحديث. }
$$

(1) مشتاق عباس معن: شعرية التتاص، قراءة في شعرية كريستفيا السلبية، علامات في

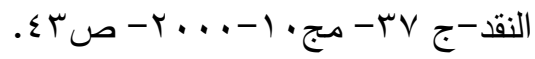

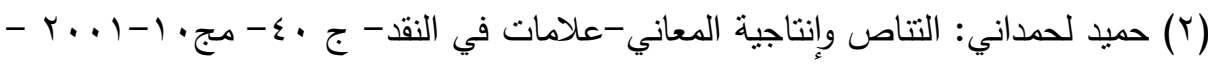




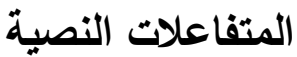

رؤية نقدية جديدة تؤكد انفتاحية النص الأدبي على عناصر لغوية وغير لغوية"(").

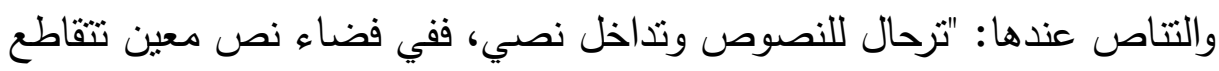

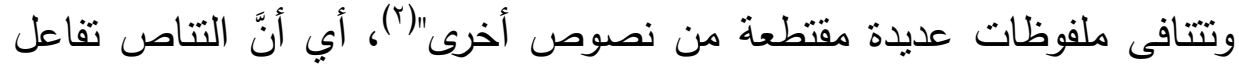

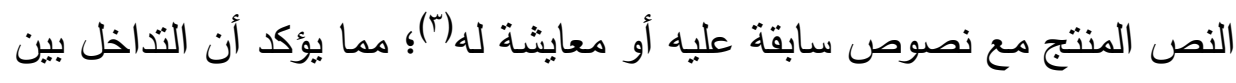

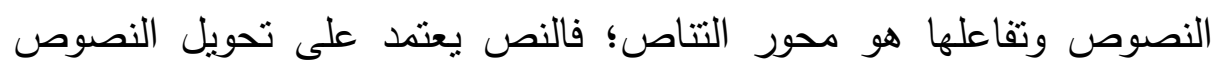

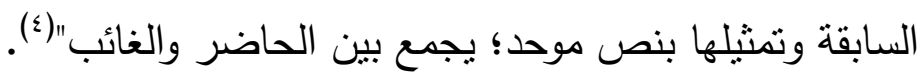

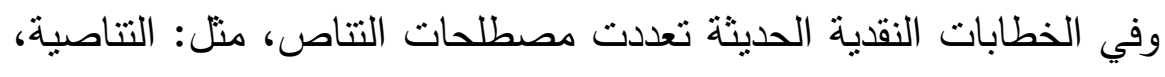
والثقابلات النصية، والتعالق النصي، والمتفاعلات النصية، والنص الغائب،

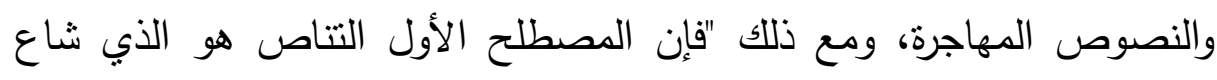

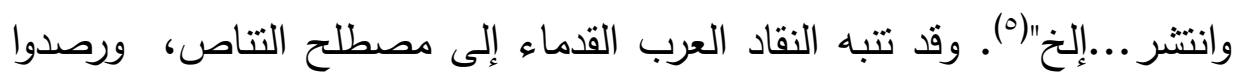
العديد من طرائق تداخل النصوص تحت مسميات اصطلاحية مغايرة، منل:

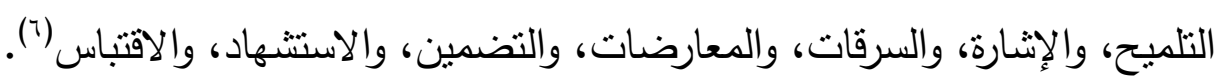

( (1) سارة بوجمعة: جماليات التتاص في شعر محمد جربوعة- ماجستير - كلية الآداب واللغات

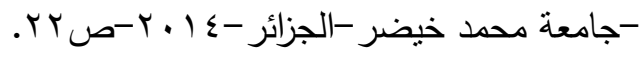

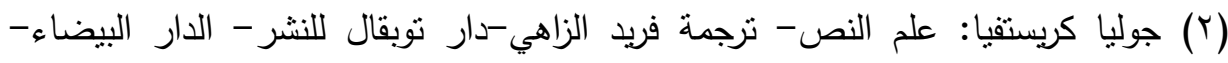

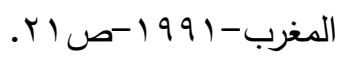

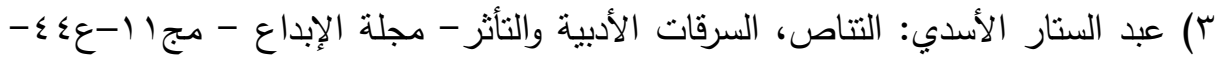

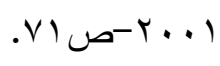

مصطفى السعدني: التناص الثعري، قراءة أخرى لقضية السرقات-منشأة المعارف

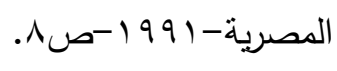

(o) محمد عزام: النص الغائب، نجليات التناص في الثعر العربي- منثورات اتحاد الكتاب

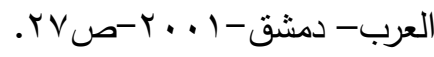

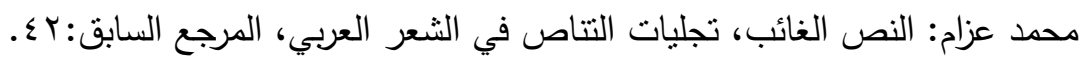


د. د محمد كمال سرحان عـ

ونظرًا للأهمية الخاصة التي يمثلها التناص في تشكيل بنية النصوص السردية؛ جاء اختيار البحث بعنوان: المتفاعلات النصية في مجموعة "حكاية الليل والطريق"، لطه وادي؛ للأسباب التالية: -شيوع ظاهرة التتاص في مجموعة "حكاية الليل والطريق" بصورة تشبه الظاهرة. -المجموعة القصصية تتسم بتوظيف مستويات تتاصية متتوعة: تراثية وحديثة. -حرص المؤلف على توظيف صور متعددة للتناص داخل نصه الإبداعي. -المجموعة القصصية قائمة على استثمار التفاعلات النصية مع مختلف الأنواع الثقافية: القديمة، والحديثة، والمعاصرة.

ويهدف البحث إلى كثف مدى حضور النصوص المختلفة داخل المجموعة القصصية، وإظهار الدور الذي تلعبه تلأك النصوص في بناء المعني، والوقوف على: أثكال التتاص، ومستوياته، وكيفية توظيفه داخل المجموعة. ودراسة التناص في مجموعة "حكاية الليل والطريق" لطه وادي؛ تتضح من وحن خلال معالجة المحاور التالية: أولًا - أثكال التناص، وتثمنل دراسته في: أ- التتاص الأتي، ويضم: تداخل الحكايات، والتكرار ، وتعدد الرواة، والبناء السردي الذي يشمل: بناء الحكاية، والعنوان، وتقسيم النص، وتتاص الثخصيات. ب-التناص الاخلي، ويضم التتاص في: العنوان، والشخصيات، وتقسيم المحكيّ، والتتاص: الشعري، والسردي، والتاريخي مع كثير من معاصريه.

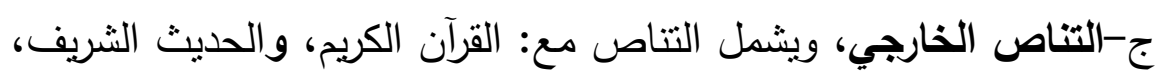
والثعر القديم، والتراث السردي، والنص الصوفي، والتناص مع كتب العها الجديا.

ثانيًا- مستويات التتاص، وتضم التتاص: الاجتراري، والامتصاصي، والحواري.

وفيما يلي دراسة التتاص في مجموعة "حكاية الليل والطريق": 


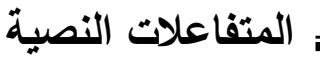 \\ أولاًا - أثكال التناص الناص}

أ-التتاص الذاتي: يراد به "العلاقات التي تعقدها نصوص الكاتب مع التهاص

بعضها، سواء على: مستوى الأسلوب، أو على مسنوى تقاطع:الموضوعات، لئل

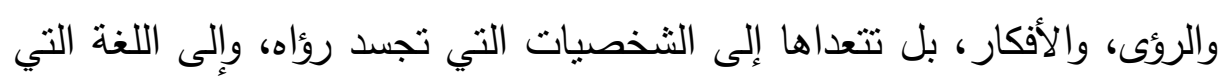

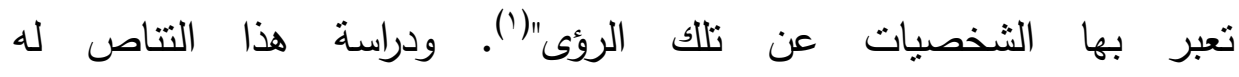
أثنره في فهم التجربة الإبداعية لاى الكاتب. ويظهر النتاص الذاتي في المجموعة

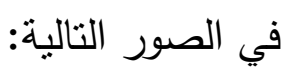

1 - تداخل الحكايات: بعتمد الكاتب في بناء قصص المجموعة على توظيف

بنية سردية حداثية؛ تعتمد على التداخل بين الحكايات، القائمة على تداخل الأزمنة

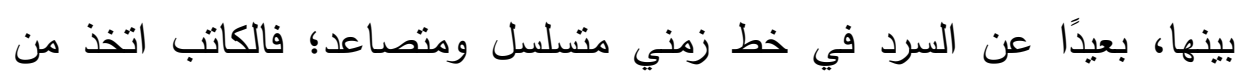

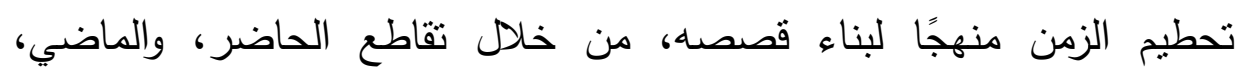

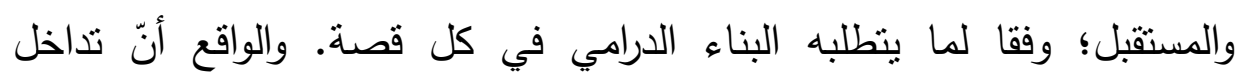

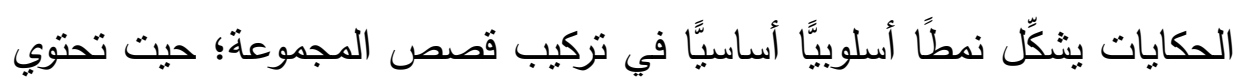

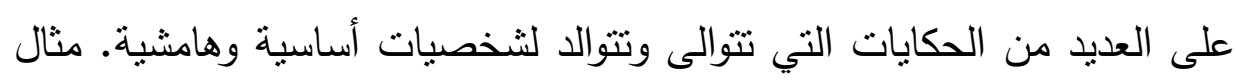
ذللك قصة "مواقف مجهولة من سيرة صالح أبو عبسى"؛ فيها العديد من الحكايات

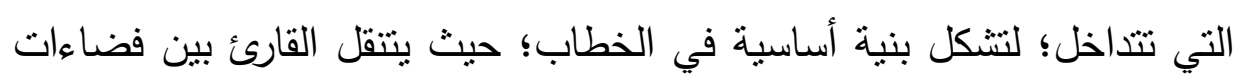

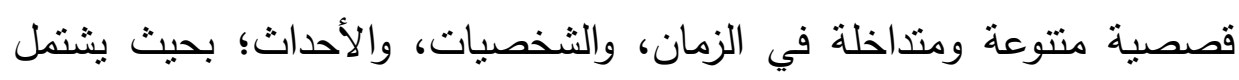

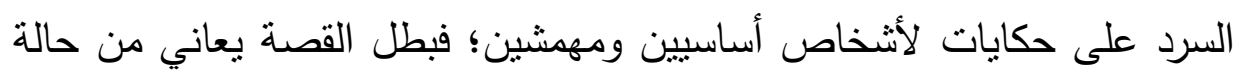

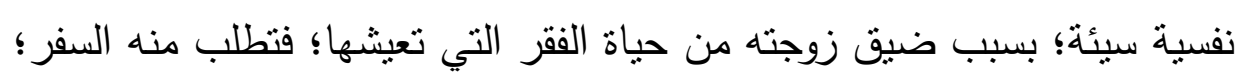

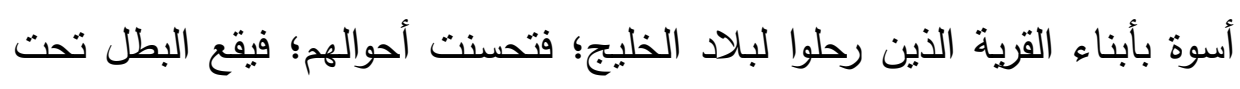

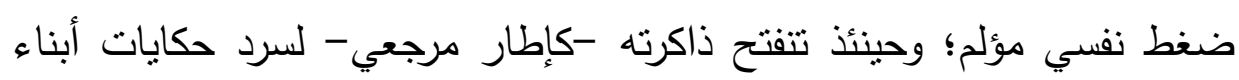

(1) أمل أحمد عبد اللطيف أحمد: التتاص في رواية إلياس خوري باب الثمس-ماجستير -كلية

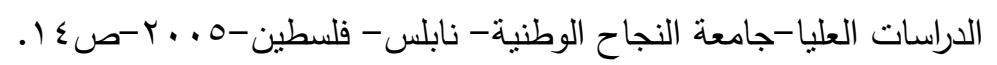




\section{د. · محمد كمال سرحان}

قريته الذين سافروا، لكنهم خسروا جوانب أخري في حياتهم؛ وهنا تتحقق عملية التذكر، وتتسال الحكايات المتداخلة وتنتظى، يقول: "هل يعجبك يا (منيرة) الولد (عامر أبو عميرة)، الذي سافر ثاني يوم زواجه، وترك زوجته، والموكوس (عبده

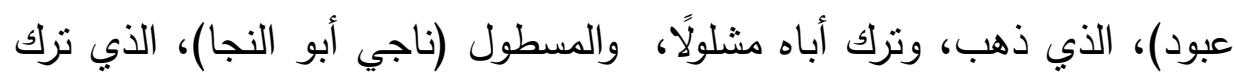
أرضه لأولاده الصغار ؛ فبار نصف الأرض، وأكلت الدودة النصف الباقي..."('). ثمّ يعود السارد للحكاية الأصلية للقصة؛ متحدثًا عن حياة البطل(صالح)، وسرعان ما يقطع السرد-مرة أخرى- ليدخل في حكاية أخرى، لـ(السيد فهيم) من خلال

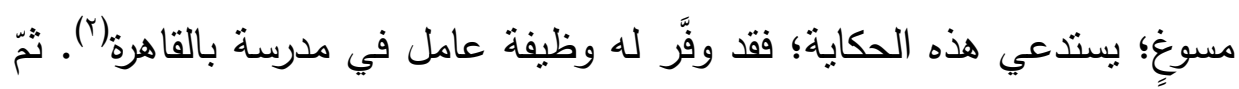
يعود لخيوط الحكاية الأم؛ فيتتاول رغبة (صالح) في السفر (ז). وبهذا يتضح أنّ التذاخل السردي في الحكاية الأصلية لا يقتصر على حكاية واحدة، وإنما قد يتعداها إلى حكايات عديدة؛ يتوالد منها حكايات أخرى، وهذه الحكايات جاءت بصورة منسجة ضمن الحكاية الأولى، كذلك جاءت معبرة عن الفكرة العامة للنص.

ץ-التكرار/ (التواتر): يطلق عليه "التواتز السردي"، ويقوم على "التكرار بين الخطاب والقصة"(๕). ويميل بعض النقاد إلى عدم إدخاله في حيز الزمان السردي، لئه

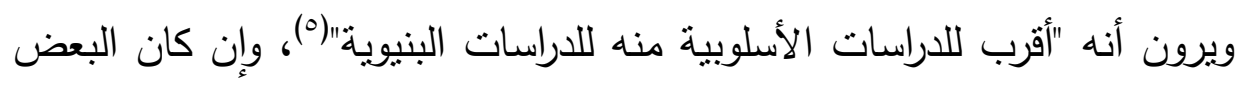

طه وادي: مجموعة "حكاية الليل والطريق"- مكتبة مصر - القاهرة- طץ-|199-1

$$
\text { صמזי. }
$$

$$
\text { (Y) طه وادي: المجموعة القصصية - صلr (Y T)، وما بعدها. }
$$

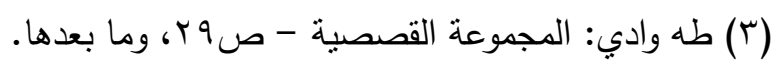

(§) جيرار جينيت: خطاب الحكاية، بحث في المنهج- ترجمة: محمد معتصم، وآخرون-

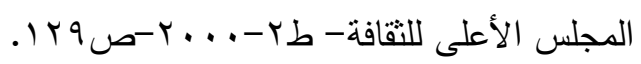

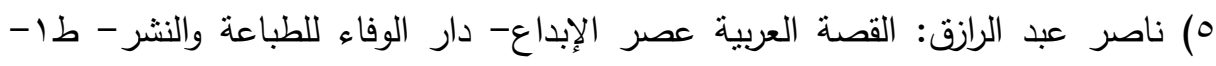




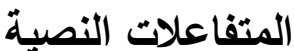

الآخر يرى أنه "عنصر قائم على جسر بين ما يخص مقولة الزمان، وبين ما

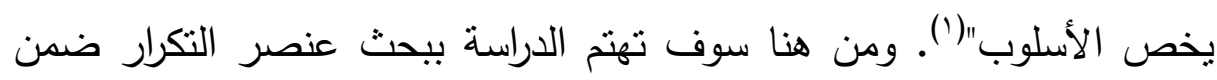
دراسة التتاص الأسلوبي بين قصص المجموعة، بعضها ببعض، وبينها وبين أعمال الكاتب عامة. ويتمظهر التكرار في المستويات التالية:

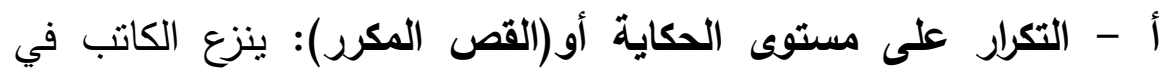

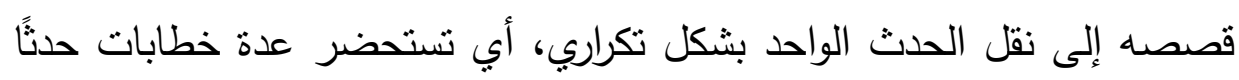

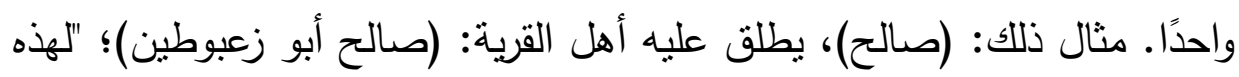

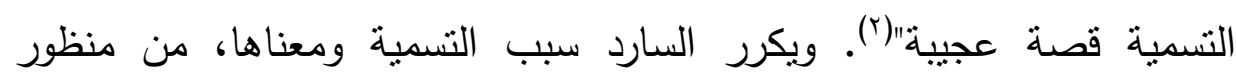

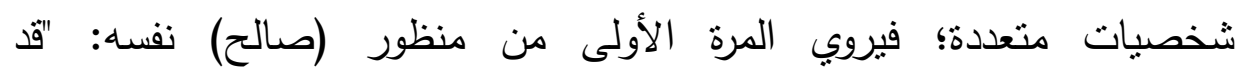

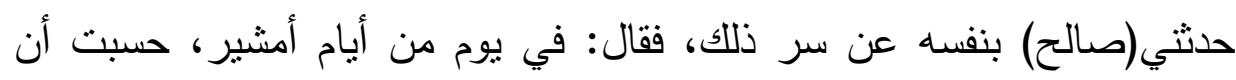

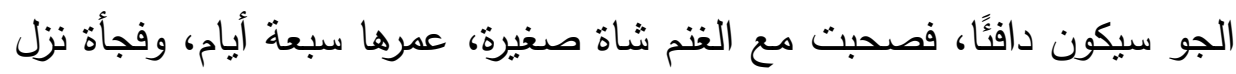
المطر بغزارة؛ فأخذت غبيط الحمار، وألبسته للثناة، وحملتها على صدئه صدري.

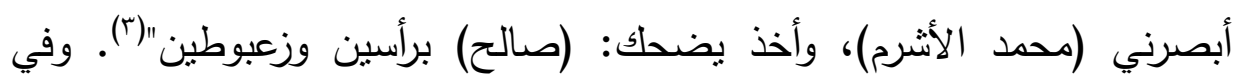
المرة الثانية يتبني بعض أبناء القرية وجهة نظر أخرى في تفسير معنى الزعبوط: لأنيا:

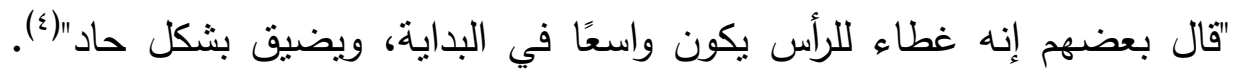

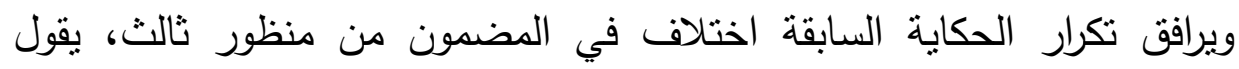
السارد: "ولكن بعض الراسخين في العلم قالوا: إنه رداء من صوف الغنم؛ يغطي لإنيان

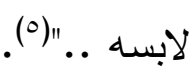

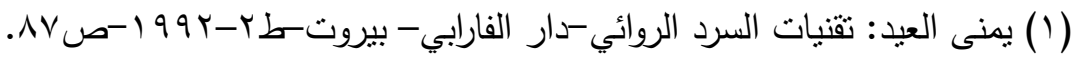

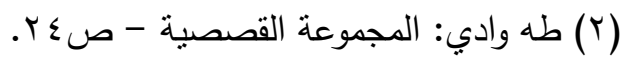

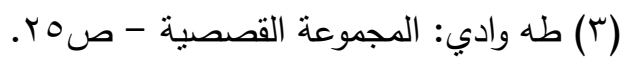

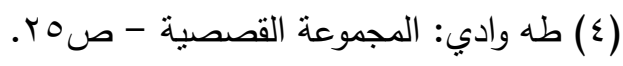

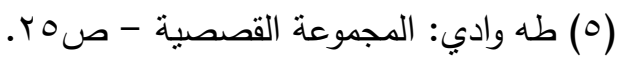

$$
\begin{aligned}
& -09 \leqslant-
\end{aligned}
$$




\section{دـ · محمد كمال سرحان}

وأحيانًا يقدم السارد القص المتكرر من منظور عدة شخصيات للحدث نفسه؛

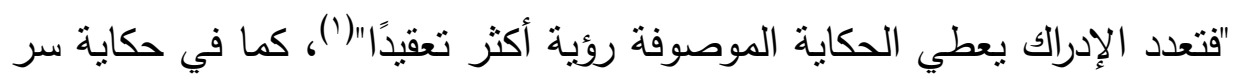
وفاة (صالح): "واحتار أهل القرية في تبرير سر الوفاة المباغتة، والميتة المُفْرِة؛ دون ألم أو حشرجة"(r). وتتكرر الحكاية -عدة مرات- على ألسنة الكثثرين: "وقد ذكر بعض المتطوعين أنّ (صالحًا) كان يعمل كثيرًا ويأكل قلياًا. والبعض قال: إنّ (صالحًا) قد وجد حقيبة مملوءة بالمال، ولم يستطع أن يتحمل الفرحة، ومات، وآخرون قالوا: إنّ نقود (صالح) ضاعت أثناء العودة؛ فمات كمدًا"(r). وبذلك يتبين أنّ أسلوب التكرار على مستوى الحكاية قد شكَّل أمرًا لافنًا؛ إذ تروي الحكايات بعدة أشكال، محاطة بسياقات مختلفة، وفي كل مرة نطلَّع على معلومات جديدة من منظور الشخصيات. ب- - التكرار على مستوى الجملة أو اللفظة: يحرص المبدع على إحداث نوع من الإيقاع الموسيقي بتكرار جملة أو لفظة؛ وهنا يكرر الراوي كلامه عن فعل واحد، وقد لا يتوالى هذا التكرار مباشرة، بل قد يتوزع على صفحات من الرواية(؛)؛ بهدف خلق نوع من التماسك بين مفاصل النص. مثال ذلك تكرار مشاعر القلق في قصص المجموعة، بتتويعات أسلوبية متعددة، منها: "ما زال القلق يسيطر مار مار

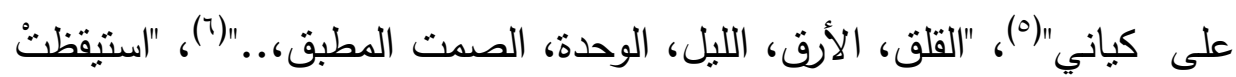
في أعماقي جذور القلق، الليل مظلم ومخيف، القلق يخرج من جسدي، اضطربت

$$
\begin{aligned}
& \text { (1) تزفيتان تودوروف: الأدب والدلالة - ترجمة محمد نديم خشفة - مركز الإنماء الحضاري- }
\end{aligned}
$$

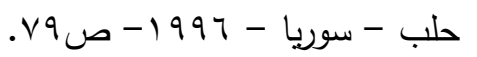

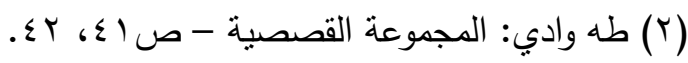

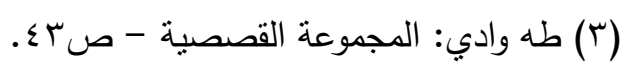

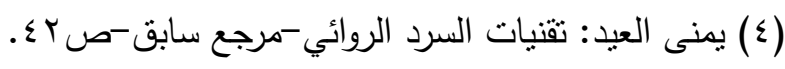

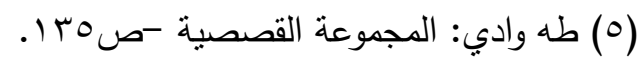

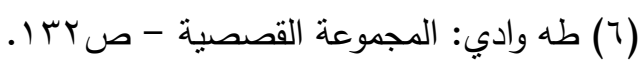

$$
\begin{aligned}
& -090-
\end{aligned}
$$




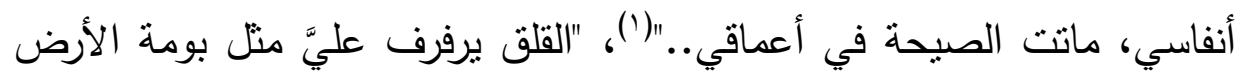
الخراب"(؟). ولا شك أنّ هذه التتويعات أحدثث شحنات إيقاعية كبيرة محملة: بالقلق، والاضطراب النفسي الذي تقع تحت ضغوطه الثخصيات. ويأتي التكرار السردي الواضح على مستوى الجملة في نكرار الراوي لجملة

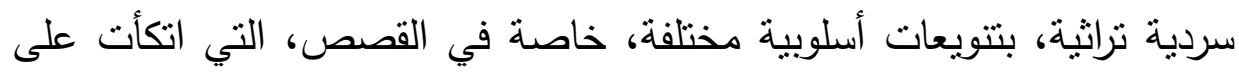

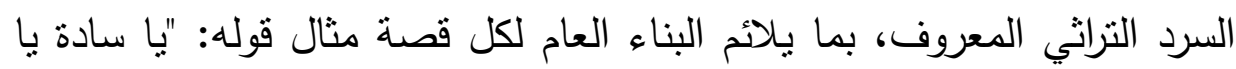

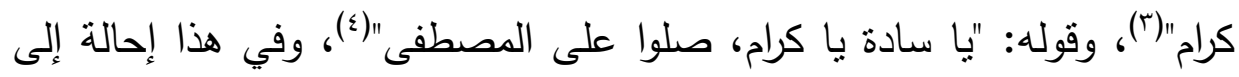
تراث: شفهي، وسردي؛ يحفل بهما إرثنا العربي، فنعيش في عوالم الم السرد التراثي، الذي نتتفسه عبر مفاصل نصوص المجموعة؛ مما يثير عقلية المتلقي، ودفعه للبحث عن العلاقة المرجعية بين: النص الحاضر، والنص التراثي.

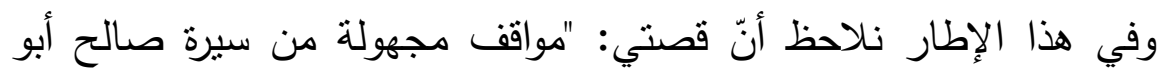

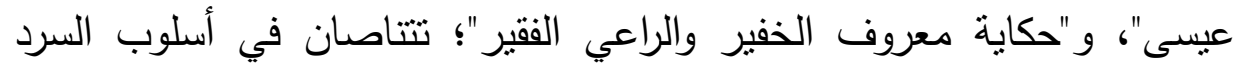
التراثي، القائم على أجواء الحكي الثنفاهي، من خلال لوازم سردية تراثية؛ تمنل

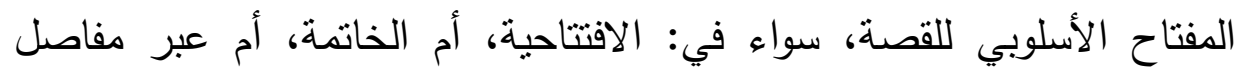

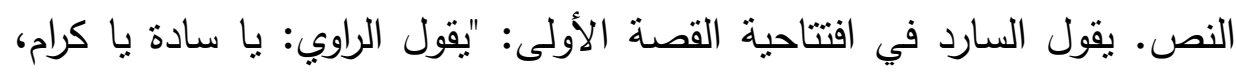

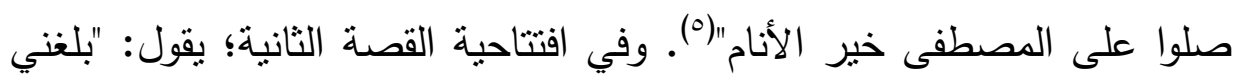

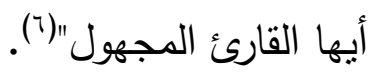

$$
\begin{aligned}
& \text { (1) طه وادي: المجموعة القصصية - ص. •با. }
\end{aligned}
$$

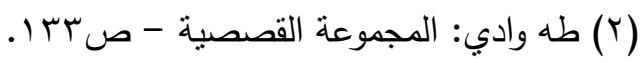

$$
\begin{aligned}
& \text { (ץ) طه وادي: المجموعة القصصية - صَ صل وما بعدها. }
\end{aligned}
$$

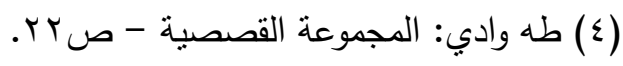

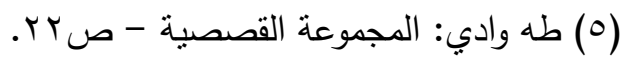

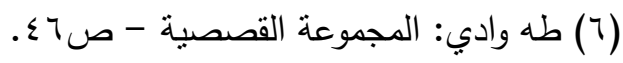

$$
\begin{aligned}
& -097-
\end{aligned}
$$




\section{د. . محمد كمال سرحان}

كذلك تتتاص -القصتان السابقتان - في النهاية السردية التراثية، ففي القصة الأولى يستخدم السارد ختامًا أسلوبيًّا -يذكرنا بأسلوب السرد التراثي في "ألف ليلة وليلة"- من خلال لازمة سردية؛ تحيلنا على الماضي: "وهنا يا سادة يا كرام طلع

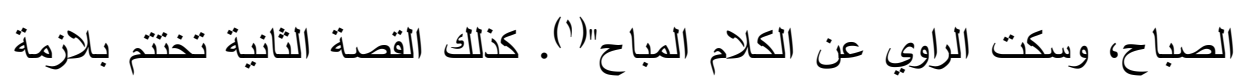
تراثية، فيها أصداء التراث وعبق التاريخ: "وهنا أدرك (دنيا زاد) المساء؛ فكفت عن

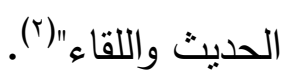

كذلك تتتاص العديد من قصص المجموعة في تكرار الفعل "قال"، وما يوازيه من القول، مثال ذلك: "قال الراوي"(؟)، "فقال في سره"(๕)، "حدثني صالح"(*)، "صاح محركًا يديه"(؟). والواقع أنّ إلحاح المبدع على تكرار فعل القول، وتتويعه على نطاق واسع؛ ينبئ عن حرص قوي لسرد حكايات شخصياته من وجهات نظر متعددة؛ لإضفاء المصداقية على المحكيّ، وتأكيد الحيادية في السرد، وترك

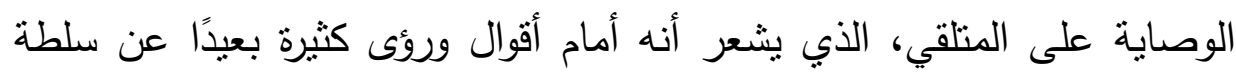

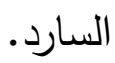

مما سبق يتضح أنّ قصص المجموعة تتناص فيما بينها، من حيث استخدام: التكرار على مستوى الجملة، أو اللفظة، كلازمة سردية؛ لها شحنات إيقاعية عالية النغم، تمنل روابط؛ تزيد تماسك النصوص، وتلقي بظله من الشعرية داخل مفاصل المحكيّ.

$$
\begin{aligned}
& \text { (1) طه وادي: المجموعة القصصية - صب ع. }
\end{aligned}
$$

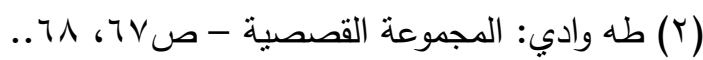

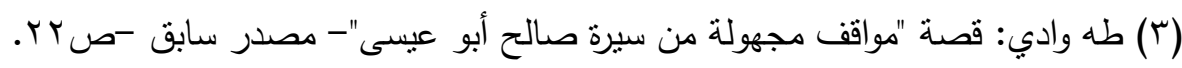

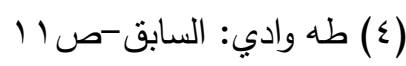

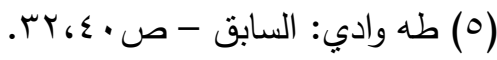

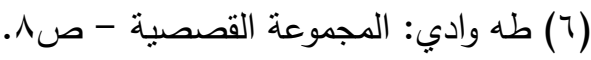


ץ-التثابه بين السارد والروائي: السارد في هذه المجموعة له خصوصية؛

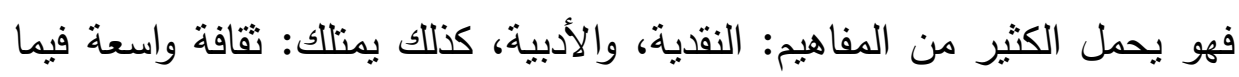

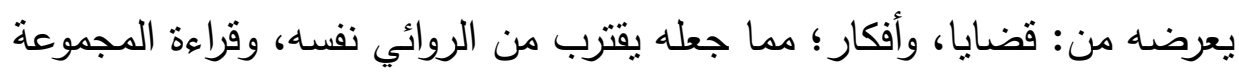
تكثف ثقاربًا واضحًا؛ بين رواة هذه المجموعة ورواة المجموعات القصصية

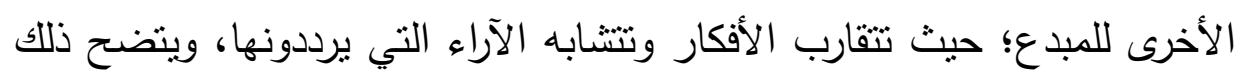
مما يلي: أ-التناص في الثقافة العلمية: السارد في هذه المجموعة يخوض في العديد

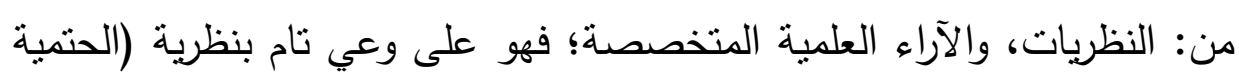

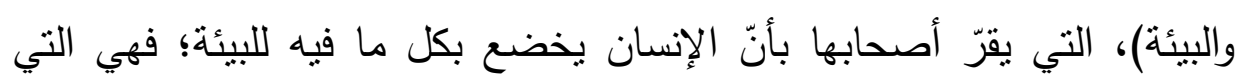

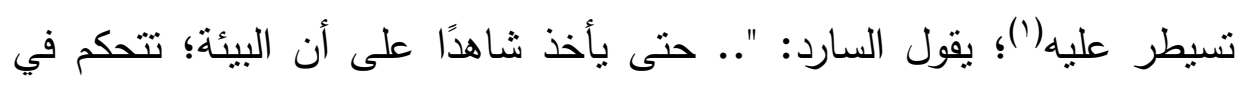

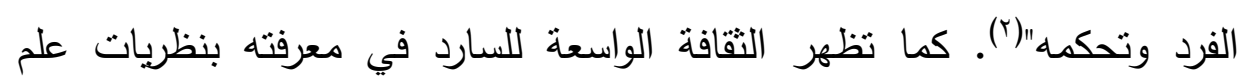

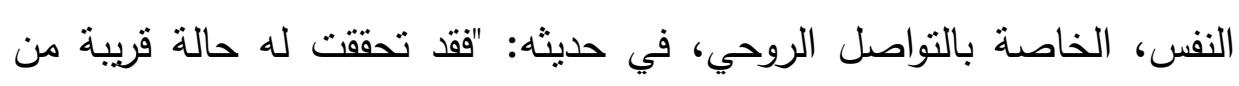

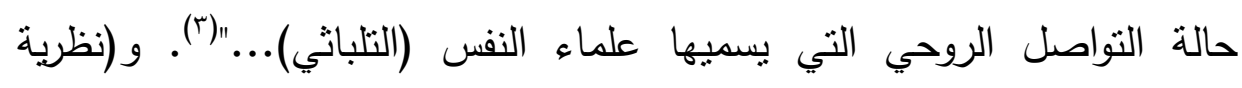
التلبثة) "توع من الاتصال العقلي بين شخصين، بحيث بستقبل كل منهما رسائل التيل

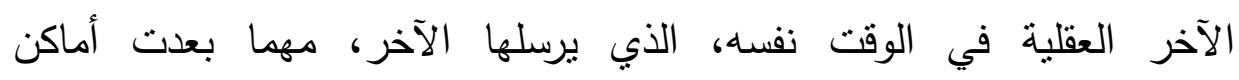

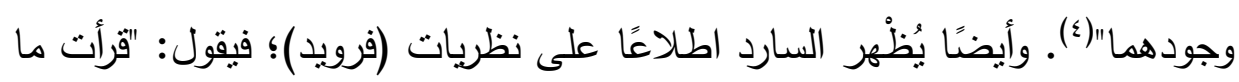

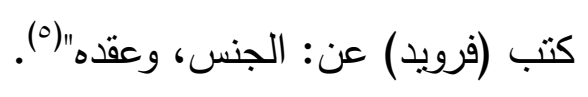

(1) محمود الأحمدية: النظريات الثلاثة في علاقة الإنسان بالبيئة- الأنباء-الأربعاء-لمايو -

$$
\text { .r. } 10
$$

$$
\begin{aligned}
& \text { (r) طه وادي: المجموعة القصصية - ص. •r. (r) }
\end{aligned}
$$

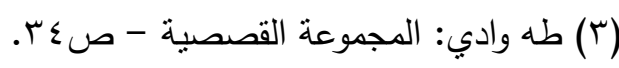

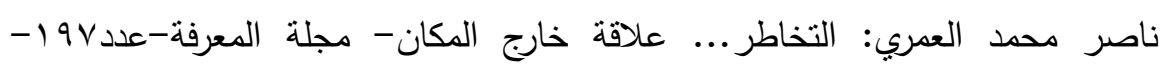

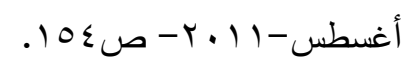

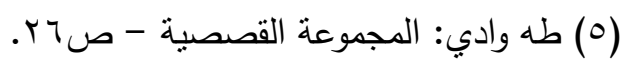

$$
\text { -091- }
$$




\section{د. د محمد كمال سرحان بـ}

ب-التناص في الثقافة النقدية والأدبية: يحرص السارد -كثيرًا- على الخوض في قضايا نقدية؛ تدور حول مفاهيم خاصة ببناء النص السردي، في

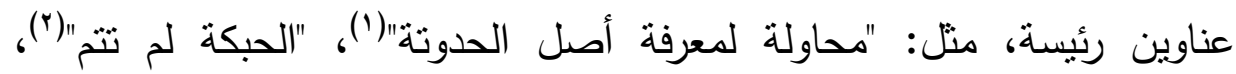
"عقدة"(")، "لحظة التتوير"(؛)؛ وكأنّ السارد متخصص في في الدراسات النقدية. كذلك يُظهر البطل اطلاعًا كبيرًا على الثقافتين: العربية، والأجنبية؛ فيتحدث عن المشاهير في: الأدب، والفكر، والفلسفة، والدين، والتاريخ، منل: دون كيخوته، ووليم شكسبير، ودانتي، وفكتور هوجو، وعروة بن الورد، والجاحظ، وواصل بن

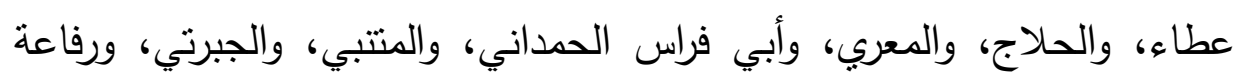
الطهطاوي.... (0).

ج-التناص في الثثافة القانونية: السادر في المجموعة على وعي كبير بالثقافة القانونية، منل حديثه (سيادة القانون): "القانون في بلادنا هو السيد الوحيد،

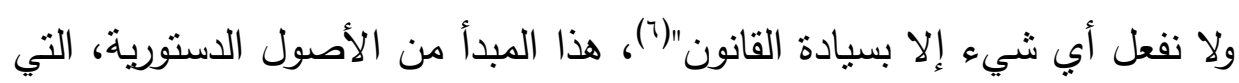
يترتب عليه: أنه لا يمكن للسلطات العامة أن نمارس سلطتها إلا وفق قوانين مكتوبة(V). كما يتتاص السارد مع قانون (الكسب غير المشروع): "من أين لك هذا"(^)، هذا القانون لدعم جهود مكافحة الفساد. والواقع أنّ السياق السردي متلائم

$$
\begin{aligned}
& \text { (1) طه وادي: المجموعة القصصية - صـ7. }
\end{aligned}
$$

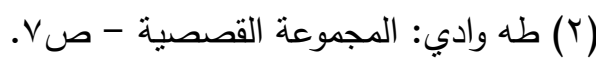

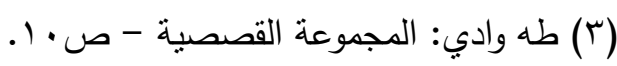

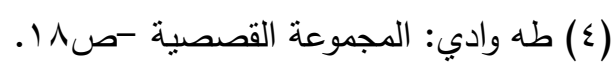

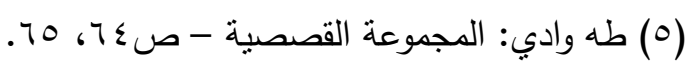

$$
\begin{aligned}
& \text { (7) طه وادي: المجموعة القصصية - ص وادي: }
\end{aligned}
$$

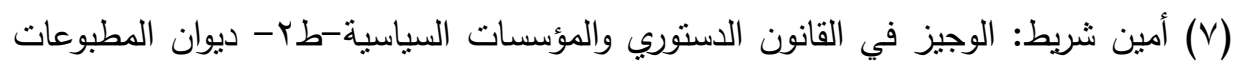

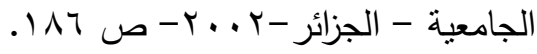

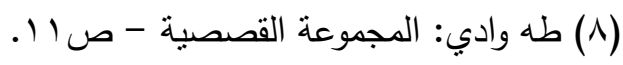




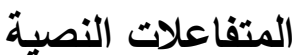

مع القاعدة القانونية؛ فكلاهما يعبر عن الرغبة القوية في مواجهة الفساد

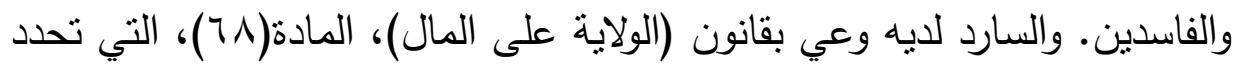

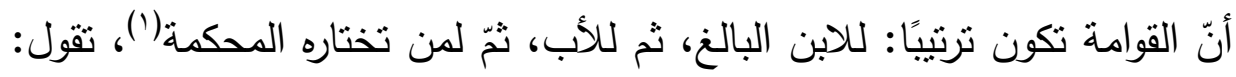

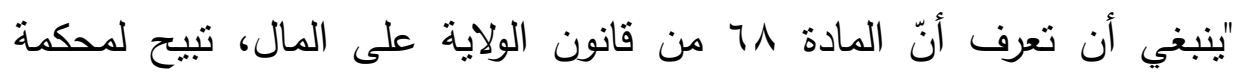

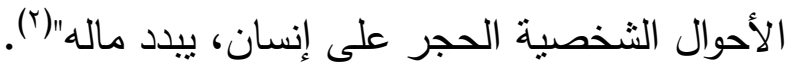

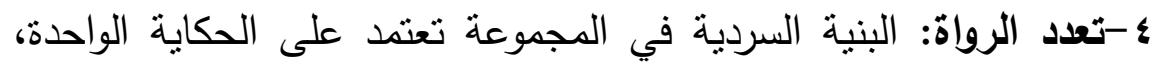

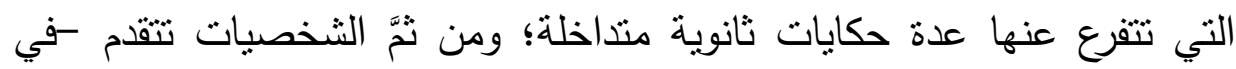

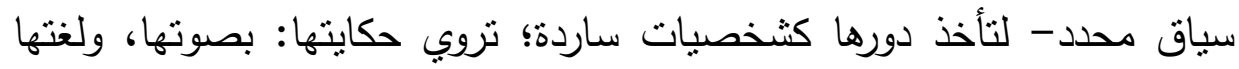
الخاصة؛ مما استدعي تقنية تعدد الرواة. ففي قصة "مواقف مجهولة من سيرة

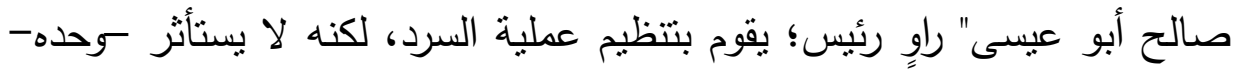

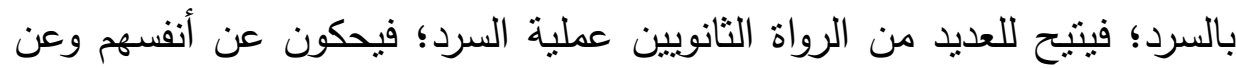

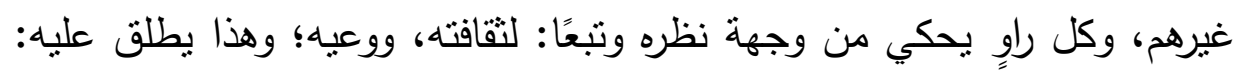

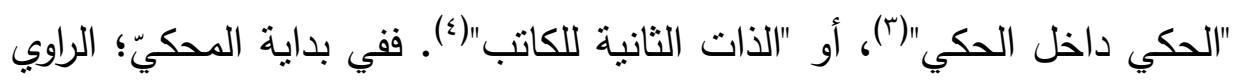
الرئيس يبدأ السرد: "أروي لكم مواقف مجهولة من حياة .."(ه). ثنَّ تثقام الثخصيات؛ لتأخذ دورها في السرد، مثال ذلك (صالح) يحكي قصة ثراء ثراء (رجب) زوج سكينة، يقول: "(سكينة)، زوجها عاد بالسلامة من السعودية..."( ("). ثمّ تتدخل

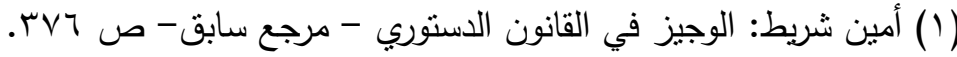

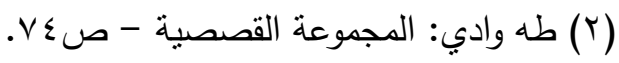

(r) أمل أحمد عبد اللطيف أحمد: التناص في رواية إلياس خوري باب الثمس - مرجع سابق ص 1 .

(ع) سعيد يقطين: نحليل الخطاب الروائي- المركز الثقافي العرب-الدار البيضاء- طr-

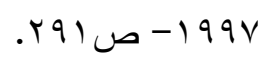

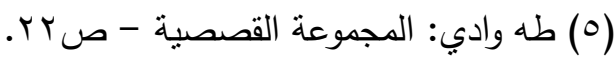

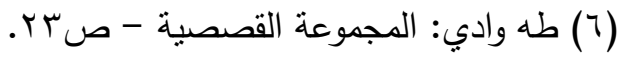




\section{د. د محمد كمال سرحان سـ}

(منيرة)؛ لتحكي -من وجهة نظرها- قصة (رجب)؛ فتتعدد وجهات النظر، تقول: "(رجب) داره الآن مبنية من الطوب الأحمر ، وغناء المسجل لا ينقطع..."( "). وقصة "حكاية معروف الخفير والراعي الفقير"؛ تقوم على تقنية تعدد الرواة؛ فراعي الغنم تُرْوى حكايته بأكثر من راوٍ، منها صوت الراوي الرئيس، يقول: "كانت الأيدي تمسك بجلباب رجل هزيل..."(؟). ثمّ بيتراجع الراوي لتأخذ

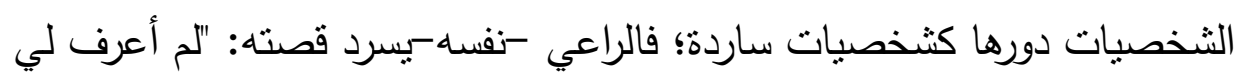
اسمًا منذ..."(")، كما يروي بعض الناس حكايته: "صاحت بعض الحناجر:

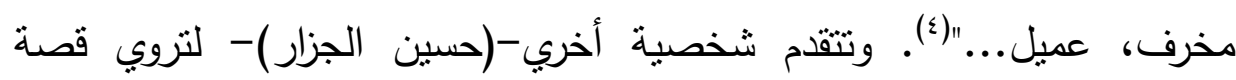
الراعي: "هذا الرجل يا سيدي، زبون جديد..."(ه). وبعود الراعي لإكمال حكايته: "قال الراعي في ثقة..."("). والواقع أن تعدد الرواة داخل المحكي، وتوزيع السرد على مختلف الشخصيات؛ تدل على ديمقراطية الراوي؛ حيث يوزع الأدوار على شخصيات النص؛ ومن ثمّ تكون شاهدة على الأحداث، ومشاركة في تحمل مسئولية حقيقة

الحكاية؛ مما يكسب القصص طابع القصة التوثيقية(V). • - البناء السردي: قصص المجموعة فيها العديد من التتاصات في البنية السردية مع كثثر من أعمال الكاتب: الروائية، والقصصية، مثال ذلك كثير ، منها:

$$
\begin{aligned}
& \text { (1) طه وادي: المجموعة القصصية - الصفحة نفسها. }
\end{aligned}
$$

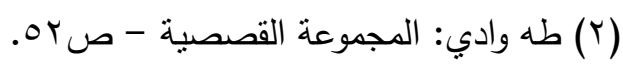

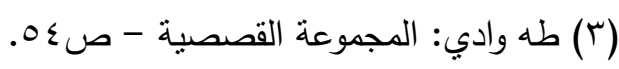

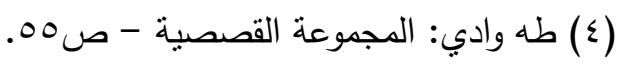

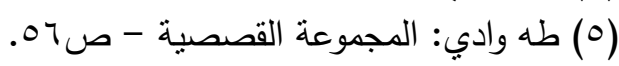

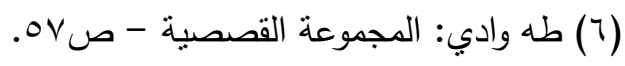

(V) أمل أحمد عبد اللطيف أحمد: التتاص في رواية إلياس خوري باب الثمس - مرجع سابق - (7) 
أ-بناء الحكاية: تنتاص قصة "مواقف مجهولة من سيرة صالح أبو عيسى"

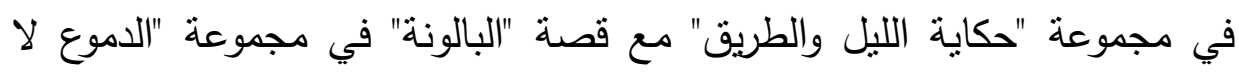
تمسح الأحزان"؛ في بنائهما السردي على الحكاية الثعبية، في القصة الأولي تبدأ:

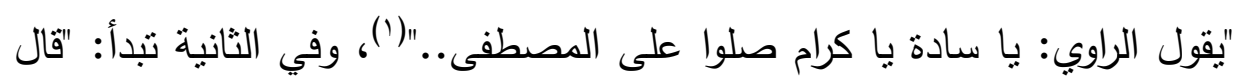

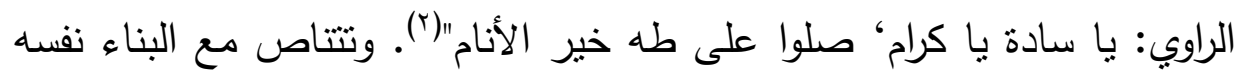
في قصة "حكاية معروف الخفير والراعي الفقير"؛ حيث تبدأ: "قال الراوي..."(").

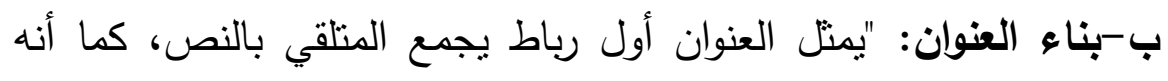

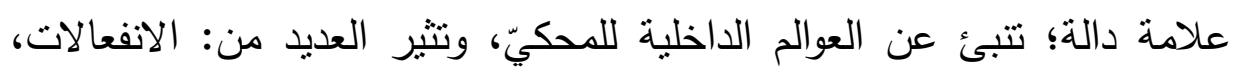

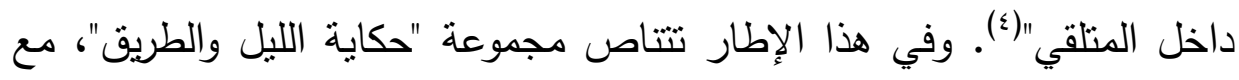

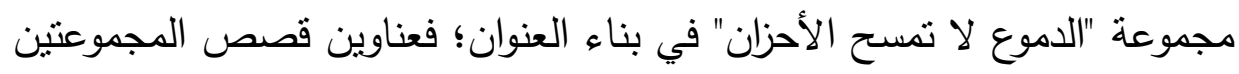

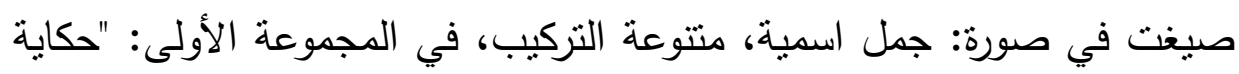

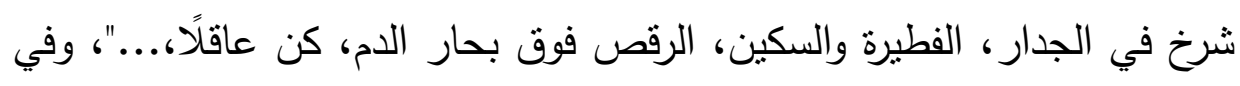

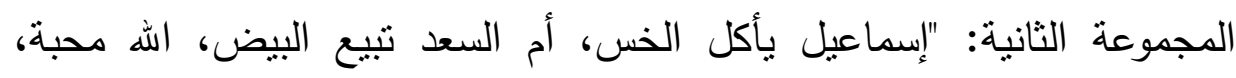

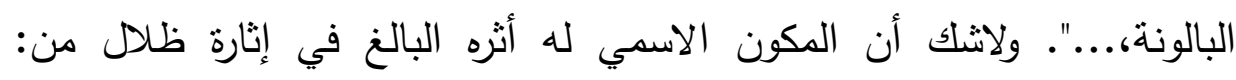

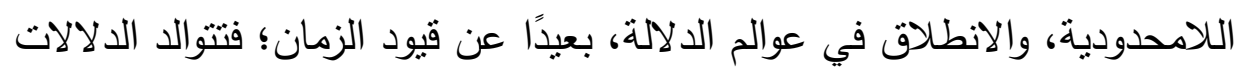

$$
\text { التي تتمرد على وضعها في إطار محدد لفكر القارئ. }
$$

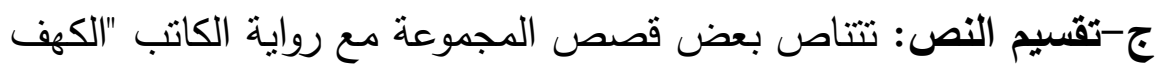
السحري" في تقسيم النص لوحدات بنائية كبرى، ذات عناوين تتسم بالحداثة، مثال ذللك قصة "حكاية شرخ في الجدار" تتقسم إلى خمس عشرة وحدة، عناوينها:

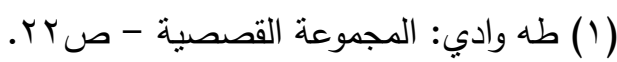

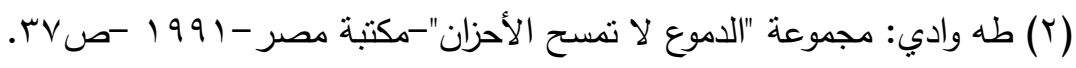

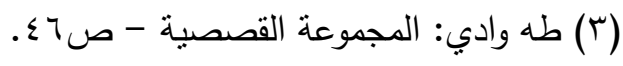

(§) فتيحة حسيني: التتاص في رواية الثمعة والدهاليز للطاهر وطار - ماجستير - كلية الآداب

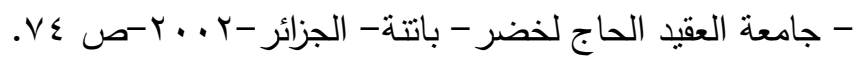


د. + محمد كمال سرحان بـ

"محاولة لمعرفة أصل الحدونة، الحبكة لم تتخ، وما تزال الحكاية غامضة..."، ورواية "الكهف السحري" مقسمة إلى ثلاث عثرة وحدة بنائية، عناوينها: "ظله متداخلة، الصوت الأول، إنهم يغتالون الأحلام، ..."(').

د- تناص الشخصيات: قارئ المجموعة القصصية يلاحظ أن شخصياتها ليست في معزل عن بعضها أو ببقية الثخصيات في أعمال الكاتب الأخرى؛ فيجد بينها تقارب، خاصة شخصيات القصص التي تعيش في بيئات متشابهة، مثال ذللك شخصية الزوجة(منيرة) في قصة "مواقف مجهولة من سيرة صالح أبو عيسى" لا تختلف -كثيرًا - في تركييتها الفنية- عن شخصية الزوجة(أم الخير) في قصة "حكاية معروف الخفير والراعي الفقير"؛ فالزوجتان متمردتان على زوجهما، وترفضان إثباع رغباتهما، الأولى ترفض قائلة: "استح يا رجل أنا تعبانة"(r)،

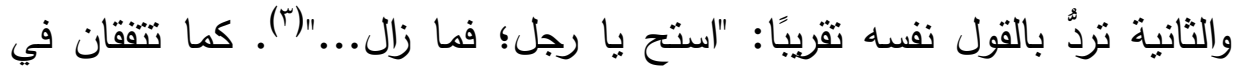
اهتمامهما بالبيت وحرصهما على الأولاد بصورة كبيرة(ء). وشخصية(عبداله) في قصة "حكاية شرخ في الجدار" نتتاص مع شخصية أحد العوام في قصة "حكاية معروف الخفير والراعي الفقير"؛ حيث بتصفان بالخضوع في المواقف؛ فالأول يستسلم لأحد المرابين ؛ قائلًا له: "ما تقوله على العين والرأس با كبير البلد"(*)، والثخصية الأخرى تستسلم لكبير البصاصين قائلة له: "القانون على العين والرأس يا كبير الحراس"(ب").

$$
\begin{aligned}
& \text { (1) طه وادي: رواية "الكهف السحري"-مكتبة مصر - د ت- ص99 1، به9. }
\end{aligned}
$$

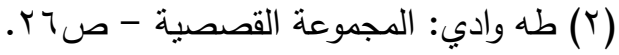

$$
\begin{aligned}
& \text { (r) طه وادي: المجموعة القصصية - ص •.0. }
\end{aligned}
$$

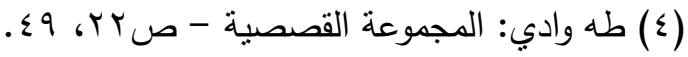

$$
\begin{aligned}
& \text { (0) طه وادي: المجموعة القصصية - ص ل1 لـ } \\
& \text { (T) طه وادي: المجموعة القصصية - ص وادي: } \\
& -7 \cdot r-
\end{aligned}
$$




\section{المتفاعلات النصية - (التية}

ومما سبق يتضح أن نصوص الكاتب تداخلت وتفاعلت مع بعضها بعضًا

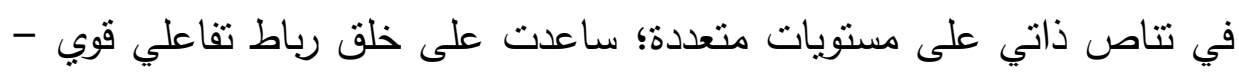

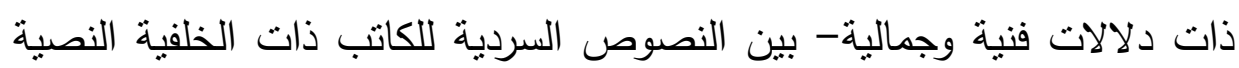

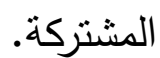

ب-التتاص الداخلي: يقع التفاعل النصي الداخلي حينما يدخل نص الكاتب

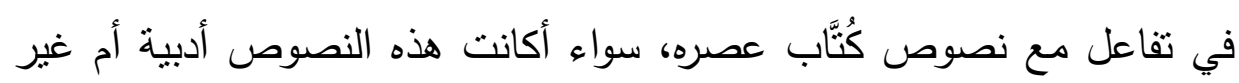
أدبية(')؛ بهدف إثراء النص؛ وكثنف قدرته على امتصاص الأجناس المعاصرة.

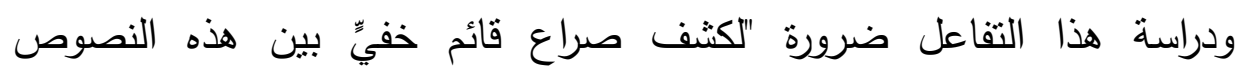

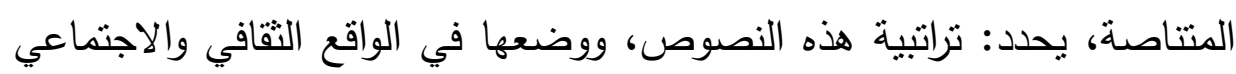

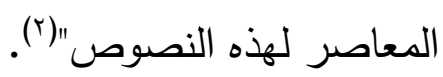

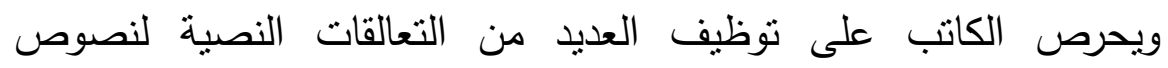
معاصريه، مثال ذلك قصة "حكاية شرخ في الجدار" في المجموعة، عنوانها

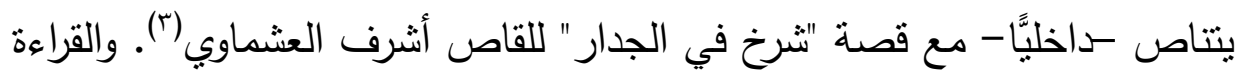

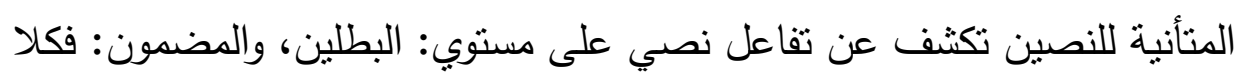

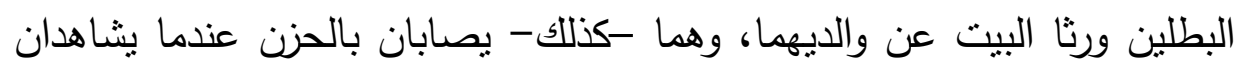

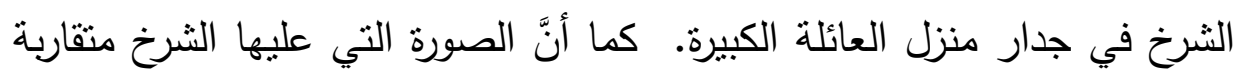
في النصين: فهو يتسع بمرور الزمن، كذلك هنالك تماس نصيٌّ لوصف الثرخ

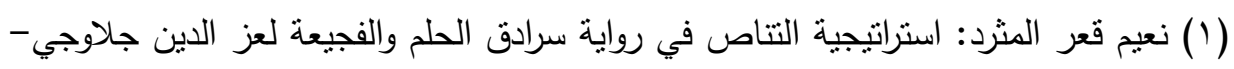

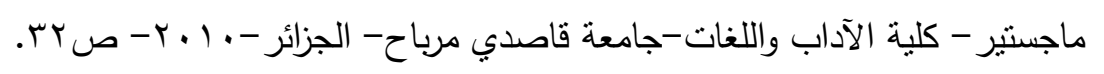

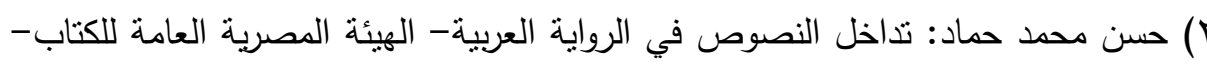

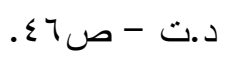

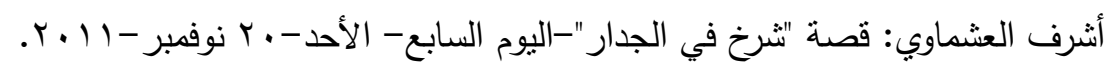


ففي المجموعة: "الثرخ اللعين...، الثرخ متعرج منل أفعى رقطاء"(!)، وفي النص كان الآخر : "الثرخ بدا، كأنه ثعبان يزحف"(؟). كما أنّ البطلين مشتركان في رغبتهما القوية في إصلاح الثرخ، وإعادة البيت لصورته الجميلة الأولى. كذلك يوجد تماس نصي في: نوظيف العنوان وتقسيم المحكي لوحدات بنائية بين قصة "حكاية شرخ في الجدار" للكاتب مع رواية "شرخ في تاريخ طويل"

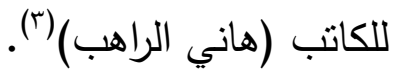
وتتفاعل قصتا الكاتب: "حكاية معروف الخفير والراعي الفقير"، و"مواقف مجهولة من سيرة صالح أبو عيسى" في أسلوب كتابة المقامة مع (محمد المويلحي) في كتابه: "حديث عيسى بن هشام"، و (بيرم التونسي) في كتابه "بيرم والمقامات"، و (بوسف السباعي) في قصة: "امرأة غيرى"؛ فيذكر الكاتب: "حدثني صالح"(ఓ)، "حدثنا الأديب الأريب"(*)، وذلك على غرار (المويلحي) في مقاماته:

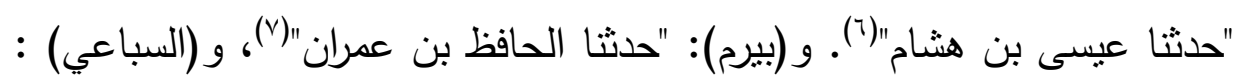
"حدثنتي المرأة، قالت" (^)

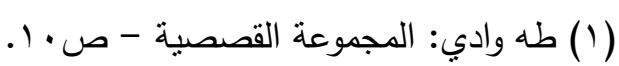
(Y) أثرف العشماوي: قصة "شرخ في الجدار"-مصدر سابق - اليوم السابع.

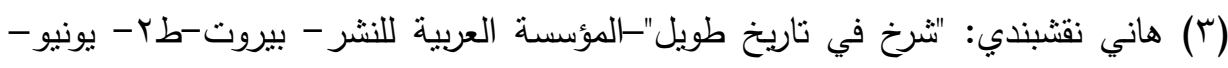

(^) يوسف السباعي: قصة "(مرأة غيرى"- مجموعة: اثتتا عشرة امرأة -مكتبة مصر - د.ت - 
وقد تتتاص بعض عبارات أبطال الكاتب مع أعمال معاصريه، مثال ذلك آلكات لئل قول البطل "آه با ليل يا قمر"((')، تتماس مع عنوان مسان مسرحية(نجيب سرور):

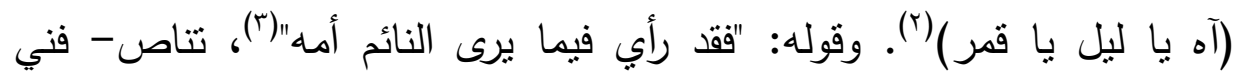

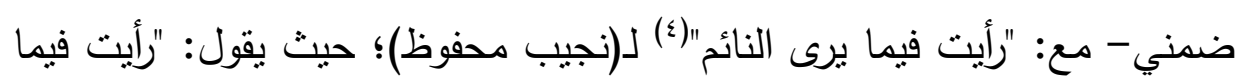

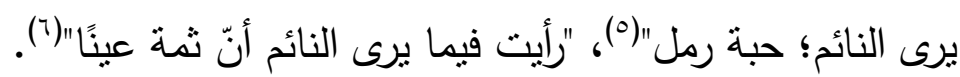

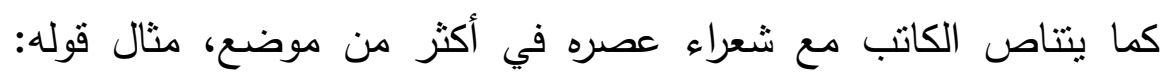

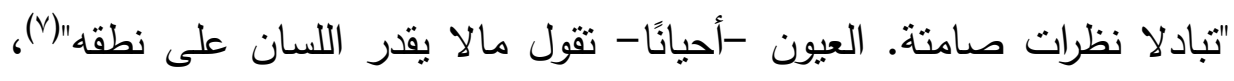

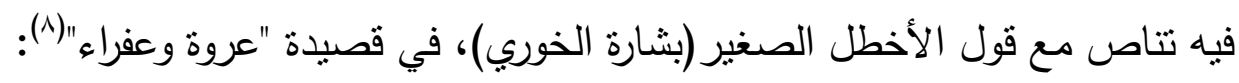

إذا التقى النظران تلمع أسطر يعيا بحل رموزها الولدان وكذللك يتتاص مع الثناعر (إبراهيم ناجي) في قوله:

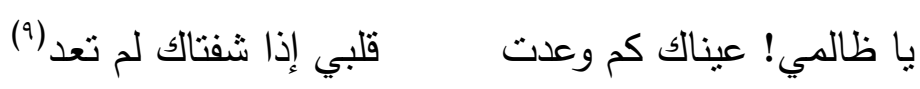

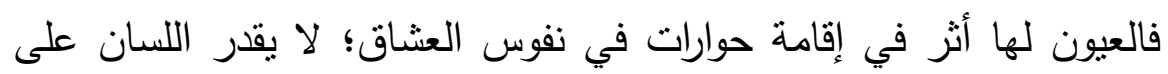
التعبير عنها؛ وهذا ما يتفق فيه السياق السردي مع السياق الثعري.

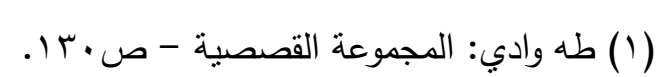

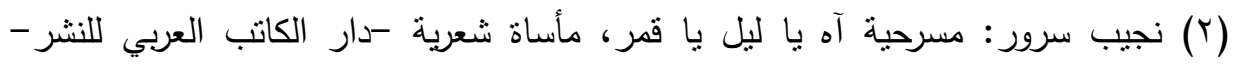
القاهرة-1941) (广) طه وادي: المجموعة القصصية - صغ بـا.

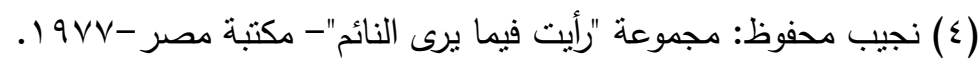

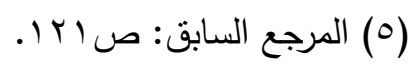

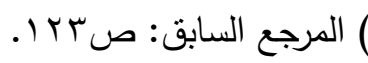

(V) طه وادي: الدجموعة القصصية - صبr (V)

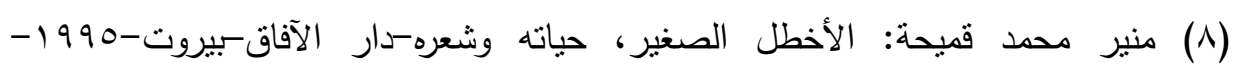
صو ا. . |إبراهيم ناجي: الأعمال الشعرية- دار العودة- بيروت-.919 1- ص بr. 
د. د محمد كمال سرحان بـ

وهناك تتاص مع الثعر في قول الراوي عن الجد(رمضان): "أمر واحد كان يثير حفيظة الجد (رمضان)، ويُحوّله إلى ضبع هائج، وهو أن يرى أحدًا يفعل ما يسيء إلى حرمة البيت الكبير. كم صاح في زوجات أولاده وبناتهم قائًاً: لا ترموا المياه بجوار الحائط، يسعل بشدة في فورة غيظه"(')، وفي هذا تتاص مع قصيدة (فاروق جوبدة): "اغضب ولا تسمع أحدًا"، يقول: اغضب ....اغضب....

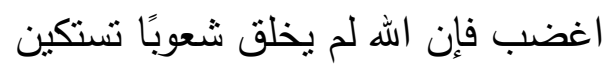

اغضب فإن الأرض تحني رأسها للغاضبين (r)

وقراءة المقطع الثعري -السابق - يكثف عن علاقة تتاصية مع السياق السردي؛ فالجد يحافظ على البيث الكبير/رمز الوطن، ويدافع عنه بكل قوة، وعندما رأى إهمال أهله؛ يثور فيهم، ويغضب صائحًا: "دن لا يحافظ على داره؛ لا يحافظ على شرفه". فالكاتب منأثز بالنص الثعري لـ(جويدة)، منفعل بكلماته، التي سيطرت عليه؛ فتمتلها في تجربته الإبداعية، في صياغة جمالية جديدة؛ مما يعزّز الترابط الجمالي الخفي بين النصين. وفي قول الثيخ: "لقد تغير الزمان والرجال.. أين الأيام التي كان.."(r)، تتاص مع (فاروق جويدة) في قصيدنيه: "لا أنت أنت ولا الزمان زمان"، و "حبيني تغيرنا" : حيث يقول في القصيدة الأولى: ما عدت أشعر في ربوعلك بالأمان

لكن شيئًا تكسر بيننا

$$
\text { (1) طه وادي: المجموعة القصصية - صل7. }
$$

(ץ) فاروق جويدة: قصبدة: "اغضب ولا تسع أحدًا"-مجموعة الأعمال الكاملة-مركز الأهرام

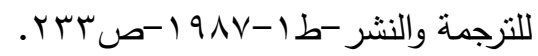

(r) طه وادي: المجموعة القصصية - ص. •r. 
لا أنت أنت ولا الزمان زمان (')

$$
\text { وفي القصيدة الأخرى يقول: }
$$

ورسالة البطل لزوجته التي يقول فيها: "أعرفلك يا زوجتي المصونة، وائه والدرة

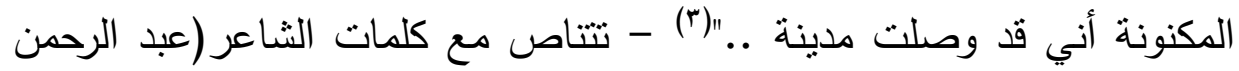
الأبنودي) في "مجموعة رسايل الأسطى حراجي لزوجته فاطنة عبد الغفار"، يقول: الجوهرة الدصونة، والدرة المكنونة.

$$
\text { زوجتتا فاطمة أحمد عبد الغفار }
$$

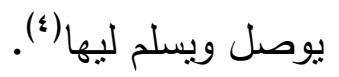

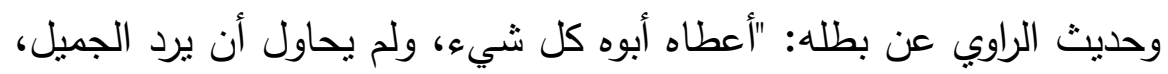

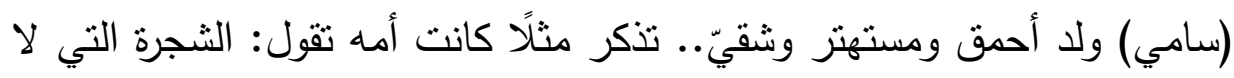

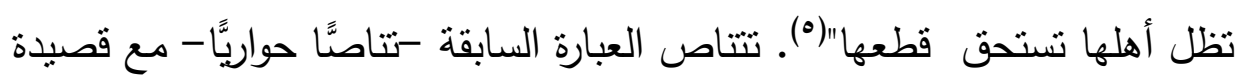

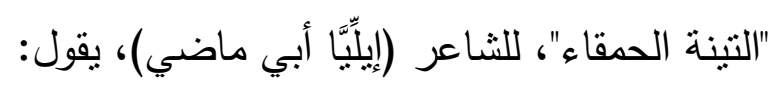

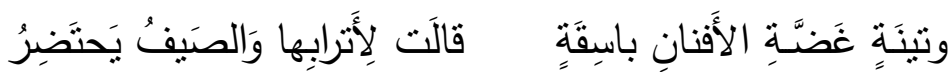

(1) فاروق جويدة: قصيدة: "لا أنت أنت ولا الزمان زمان"- مجموعة الأعمال الكاملة- مرجع

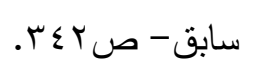

(r) فاروق جويدة: قصيدة: "حبييتي تغيرنا"- مجموعة الأعمال الكاملة- مرجع سابق-

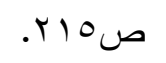

(ץ) طه وادي: الدجموعة القصصية - صب آس.

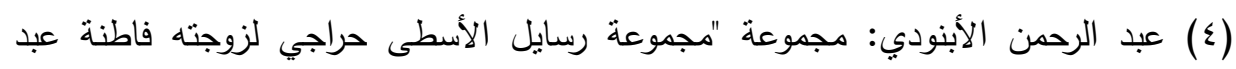

الغفار" - الموسوعة العالمية للثعر العربي.

(0) طه وادي: الدجموعة القصصية - صع 9. 


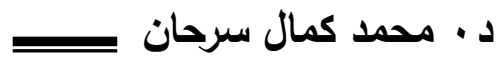

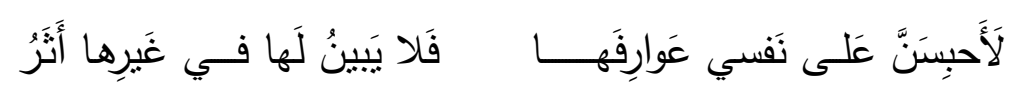

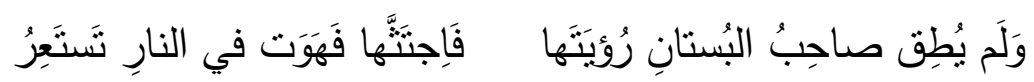

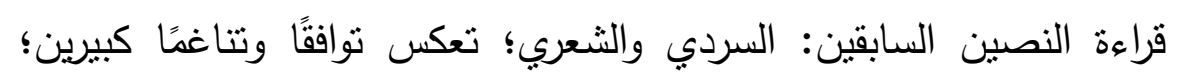

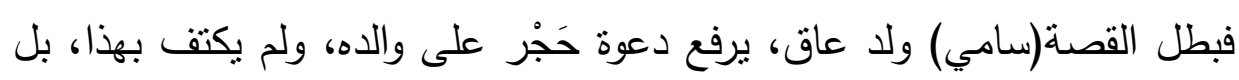

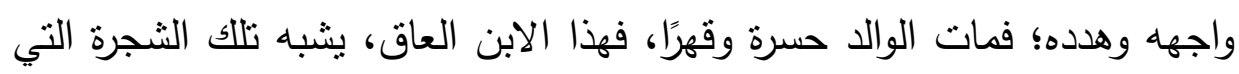

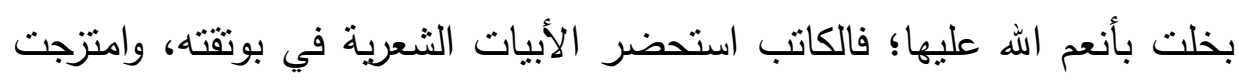

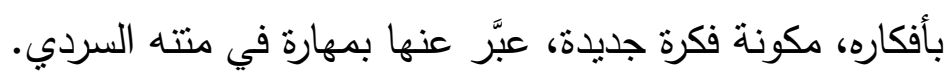

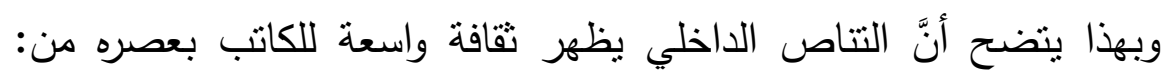

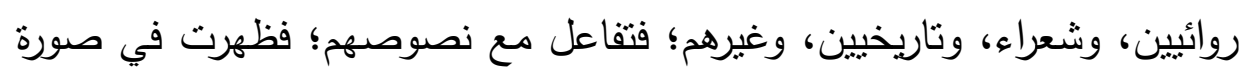

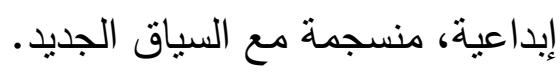
ج-التناص الخارجي: يقع النتاص الخارجي عندما "تنفاعل نصوص الكاتب التبات مع نصوص غيره التي ظهرت في عصور بعيدة عن عصره، ويسمى بالتتاص

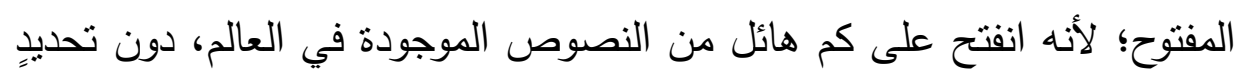

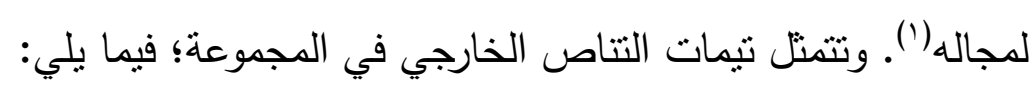

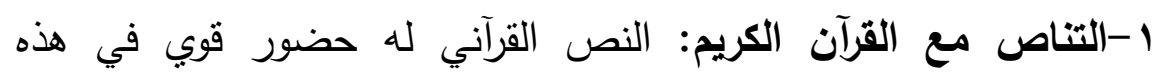

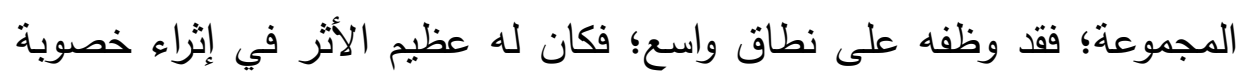
النص وتجديده. وتتوع التتاص داخل المنن في المستويات التالية:

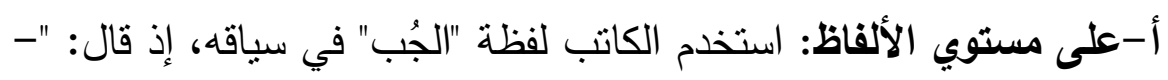

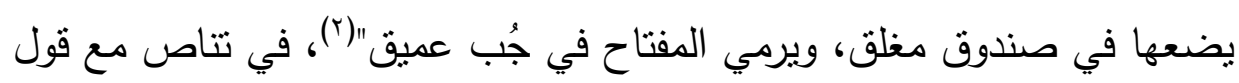

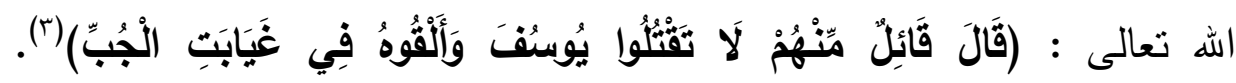

(1) حسن محمد حماد: تداخل النصوص في الرواية العربية- الهيئة المصرية العامة للكتابدت-صT كـ.

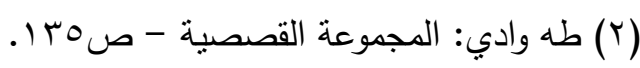

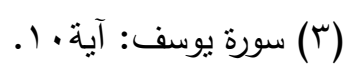




\section{المتفاعلات النصية}

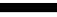

كما استخدم لفظة "أهش" في قوله: "أنا سيد الغنم؛ أهش على هذه، وألاعب

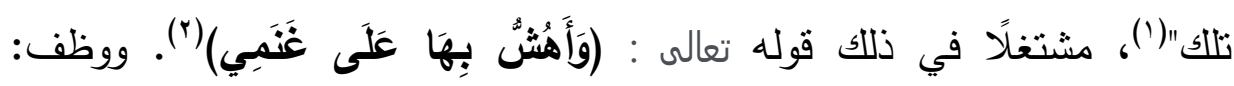

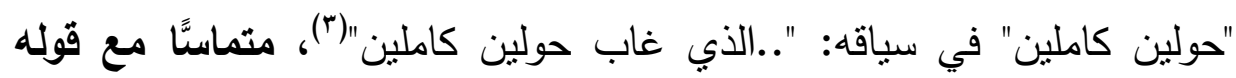

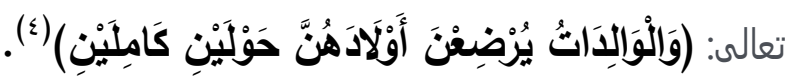

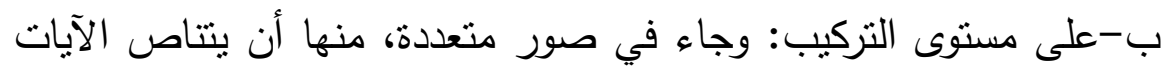

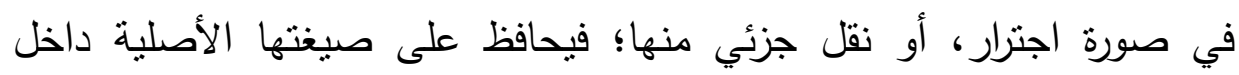

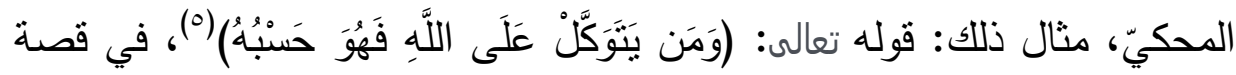

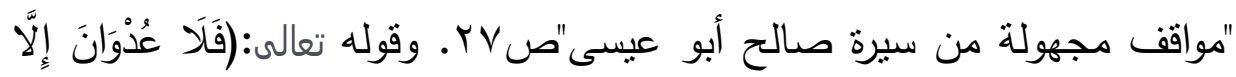

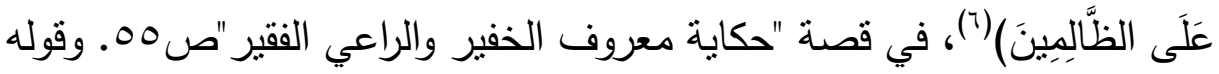

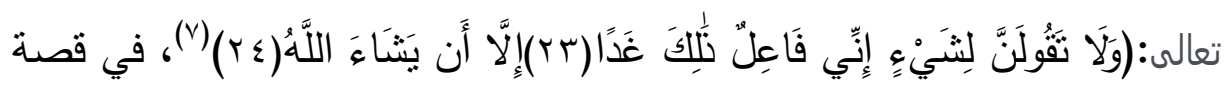

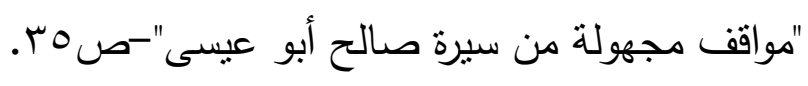

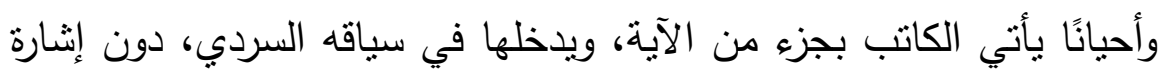

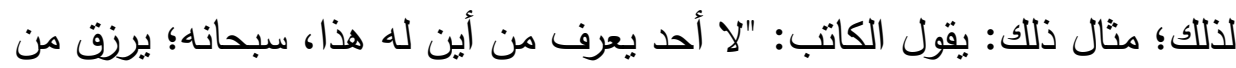

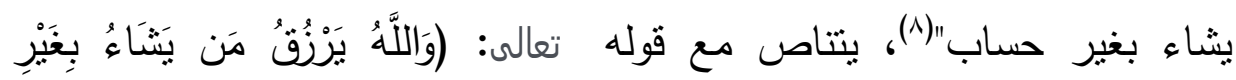

$$
\begin{aligned}
& \text { (1) طه وادي: الدجموعة القصصية - صوף؟. }
\end{aligned}
$$

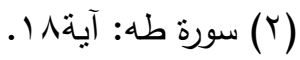

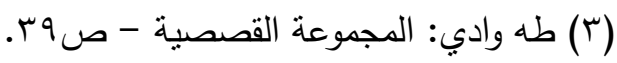

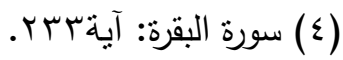

$$
\begin{aligned}
& \text { (0) سورة الطلاق: الآيتان:r، r. r. }
\end{aligned}
$$

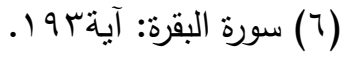

$$
\begin{aligned}
& \text { (Y) سورة الكهف: آيةrr. }
\end{aligned}
$$

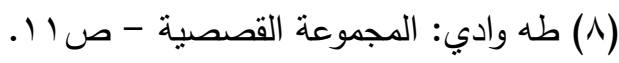




\section{د. - دحمد كمال سرحان}

حِنَابٍ)('). وقوله: "(استبقظ فزعًا، كأنما يتخبطه الشيطان من المس"(r) قوله تعالى:

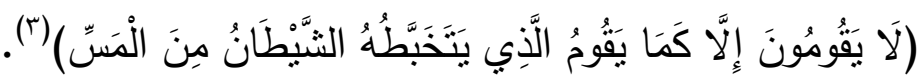
ويتطلع المنن السردي في المجموعة للتناص مع القصص القرآني لتفجير دلالات متعددة؛ "فالقصة القرآنية رافد من روفد الإبداع الفني لما فيها من متعة

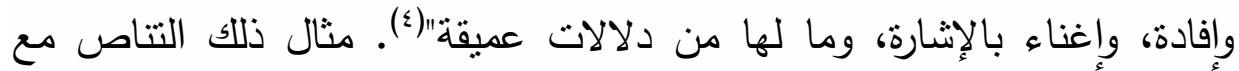
قصة سيدنا(نوح) -عليه السلام-: "العادة أن يحاسب الآباء أبناءهم، أما أن يحاسب الأبناء الآباء فهذه بلا شك آية من آيات القيامة. حين عصي نوحًا ابنه؛ جاء الطوفان ؛ وغرقت الأرض"(ْ). الكاتب -هنا- يُحَلِّق في فضاءات قصة سيدنا(نوح)، يوم دعا ابنه؛ ليركب دعه؛ خوفًا عليه، بوعي النبي، وبإحساس الأبوة، لكنَّ الابن العاق -بنظرته الضيقة، وضعف إيمانه- لا يعي نصيحة الأب؛ فيتمرد، ويتمادى في عصيانه، وهذا ما يتعالق معه المنن القصصي-في عقوق الوالدين، مع اختلافات في المضمون-حيث الابن(سامي) عاق، متمرد؛ يواجه والده، ويهدده؛ فيموت الأب حزنًا (؟). وعندما علم الابن الأكبر بجريمة أخيه مع والده؛ أصابته حالة من الغيظ، واستقر تفكيره على الصدام مع أخيه، مستدعيًا قصة(هابيل) و(قابيل): "لابد من إيقاف المصيية ومنع الفضيحة بأية وسيلة، (هابيل) لابد أن يواجه (قابيل)!"(Vابل)

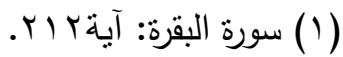

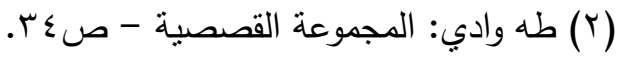

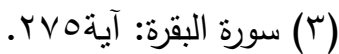

(ع) علي عشري زايد: استدعاء الثخصيات التراثية في الثعر العربي المعاصر -الثركة العامة

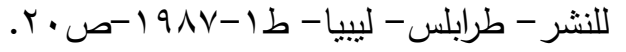

(0) طه وادي: المجموعة القصصية - ص •^. (7) طه وادي: المجموعة القصصية - الصفحة نفسها. (V) 


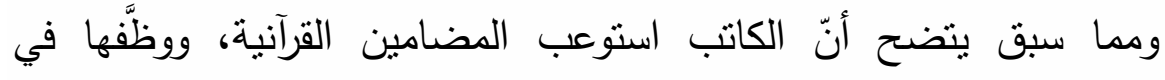
مستويات متعددة؛ ليخدم نصوصده السردية، كما اعتمد على القصص الفص القرآني

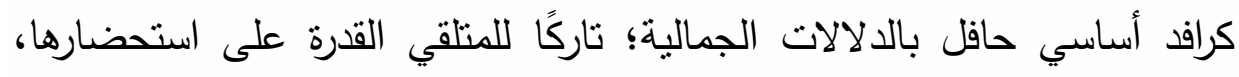
وربطها بالسياق.

ץ-التناص مع الحديث الثريف: الحديث النبوي له حضور واسع في نصوص الكاتب؛ حيث حرص على استحضاره في متته القصصي، وإعادة

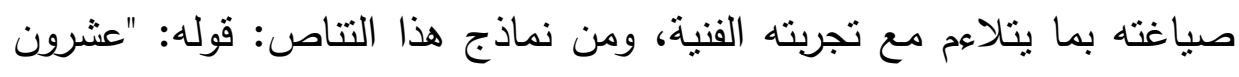

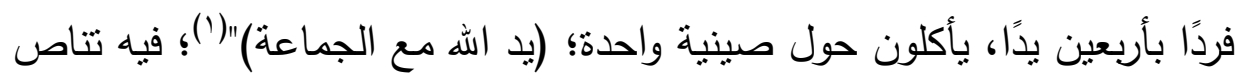

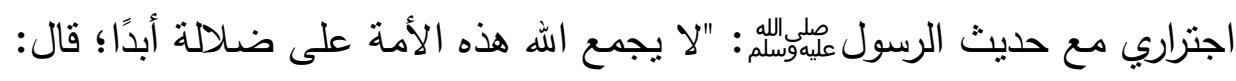

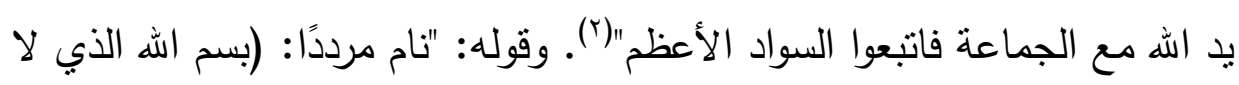

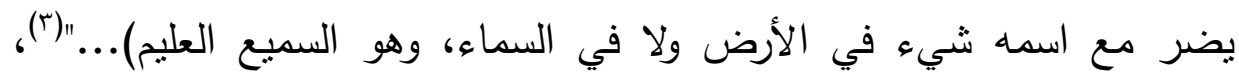

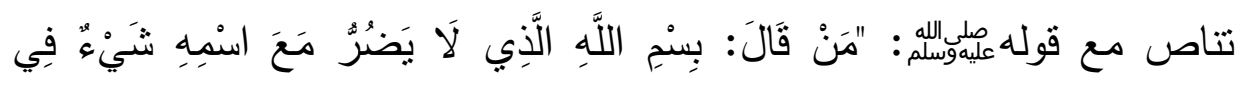

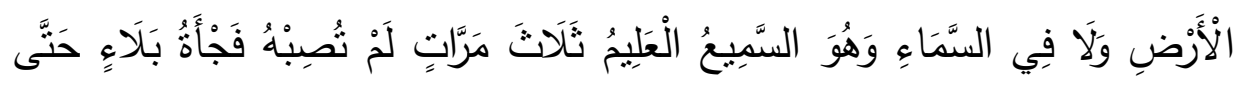

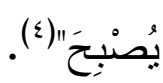

ويأني نموذج آخر من التتاص الاجتراري، باستحضار جزء من الحديث

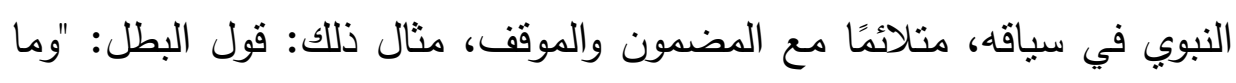

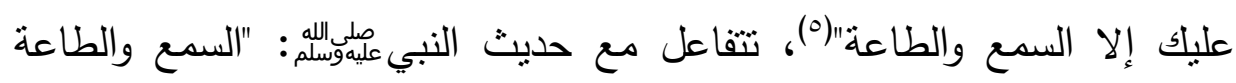

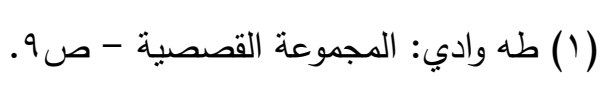

(Y) الإمام أبو عبد الله محمد بن إسماعيل البخاري: صحيح البخاري- دار ابن كثير للطباعة

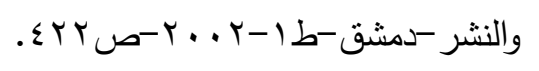

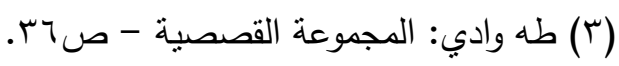

(الإمام أبو عبد الله محمد بن إسماعيل البخاري: صحيح البخاري-مرجع سابق-

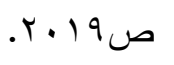

(0) طه وادي: المجموعة القصصية - ص (T). 
على المرء المسلم، فيما أحب وكره، ما لم يؤمر بمعصية، فإذا أمر بمعصية فلا سمع ولا طاعة"('). وقوله: "سأل نفسه: هل يعرف الموتى قسوة ما يعانيه أحبابهم في الحياة الدنيا، وهل طلوع الروح يمنع الوصال بين عالم الحياة وعالم

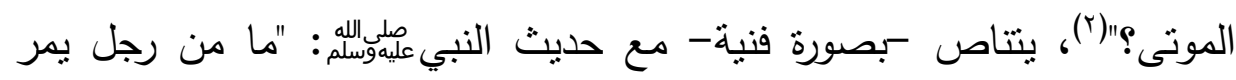
بقبر أخيه المؤمن، كان يعرفه؛ فيسلم عليه، إلا عرفه، وردّ عليه السلام، فإن لم يعرفه وسلم عليه؛ ردّ عليه السلام"("). ويأتي نموذج آخر في التتاص مع الحديث، من خلا التماس معه في الثكل الذي يخرج به الحديث، مثل: السند، وتعدد الروايات، والعنعنة. مثال ذلك استخدام لغة الفعل الماضي، في تقديم: الأخبار، مثل: قال، حدثي، أخبر، كما في سبب تسمية البطل بـ(أبي زعبوطين)، متتاصًا مع الحديث في الإسناد: "حدثني صالح..، وقال بعضهم..، ولكن بعض الراسخين في العلم قالوا..."(؛). ومنل: "احتار بعض مريديه في تعليل ذلك، منهم من ردها إلى...، وقال (صالح) ...، كما ردها بعضهح إلى...6 ومنهح من قال...، ومنهم من رأى.."(•). ومثال العنعنة في نقل الأخبار قوله: "حدثثا محمد بن عمران، عن أبيه، عن جده، عن أبي حية النميري، قال..."(†').

الإمام أبو عبد الله محد بن إسماعيل البخاري: صحيح البخاري- مرجع سابقص1V70.

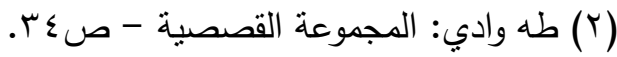
(r) ابن القيم الجوزية: الروح في الكلام على أرواح الأموات والأحياء بالدلاثل من الكتاب والسنة والآثار وأقوال العلماء-حققه محمد اسكندر يلدا-دار الكتب العلمية-بيروت-لبنان -

$$
\text { ط }
$$

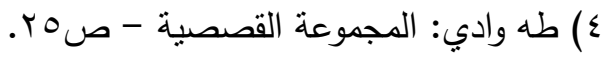

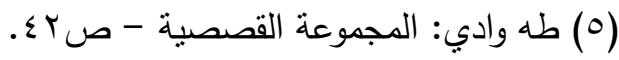

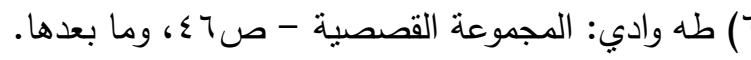




\section{المتفاعلات النصية}

وتزداد عناية الكاتب بإثراء نصوصده السردية حدًا كبيرًا؛ فيحرص على الفي

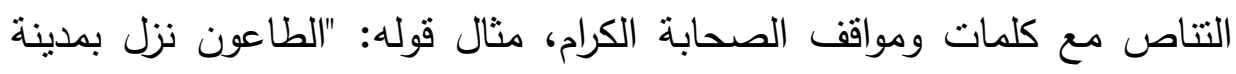

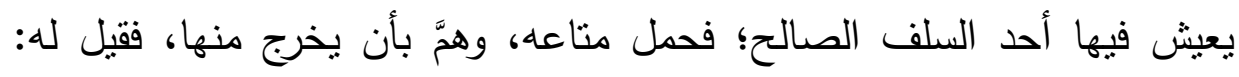

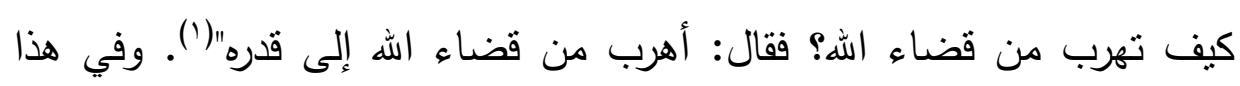

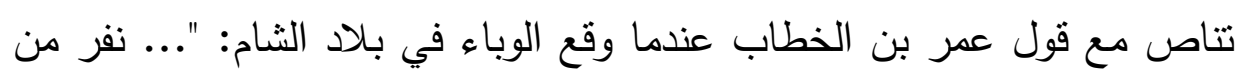
قدر الله إلى قدر الله (r).

ومما سبق يتضح أن المتن القصصي قد ضُمِّن كمًا كبيرًا من التفاعلات

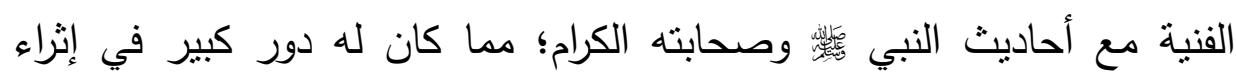

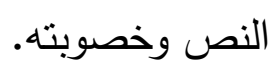

r- التتاص الصوفي: حرص الكاتب على إثراء متته السردي بإقامة علائق ووشائج مع عوالم الروحانيات الصوفية؛ مما زاد من جمالية تجربته الإبداعية.

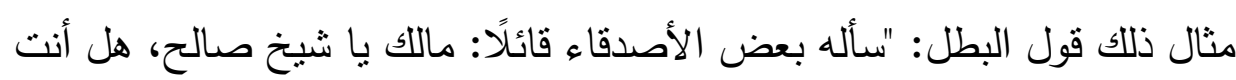

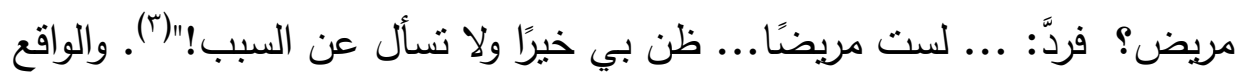

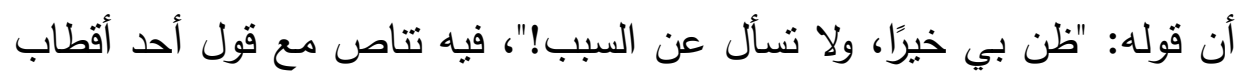

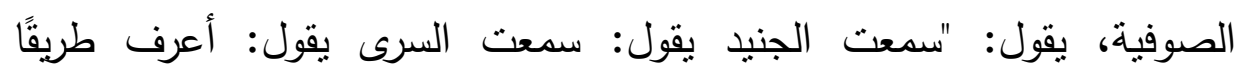

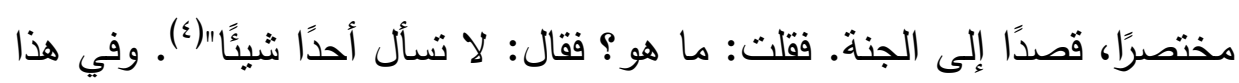

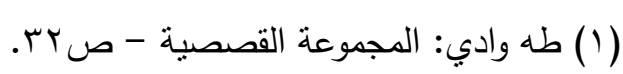

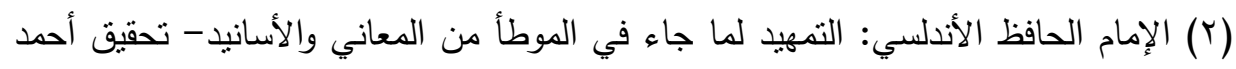

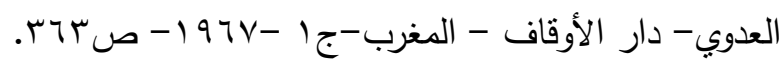

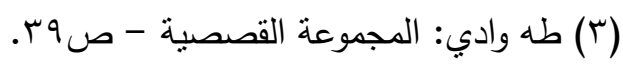

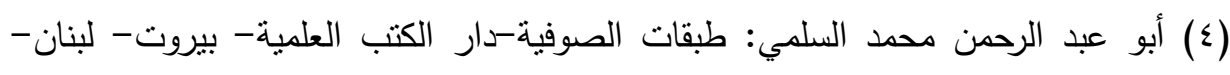
طr-r... 


\section{د. · محمد كمال سرحان}

تتاص -أيضًا- مع قول الإمام (الغزالي): "ويوحي الذي لابسته تلك الحالة، ألا يزيد على أن يقول:... فظن خيرًا ولا تسأل عن السبب" (1). وقوله عن(صالح): "أصبح لا يكلم الناس إلا رمزًا، وقد ظن كثير من زمائه

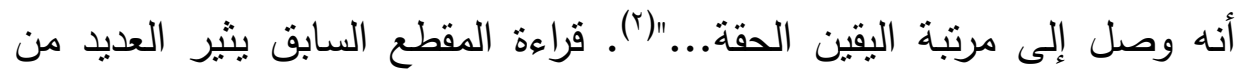
الحمولات الدلالية والمجازية التي تشير إلى مرتبة صوفية عالية، هي درجة (حق اليقين)، يقول الجرجاني في(التعريفات) "هي فناء العبد في الحق، والبقاء به: علمًا، وشهودًا، وحالًا، لا علمًا فقط؛ فعلم كل عاقل الموت عين اليقين، فإذا عاين الملائكة فهو عين اليقين، فإذا ذاق الموت فهو حق اليقين"(َ). وقراءة السياق السردي يظهر ما بتسم بـ(صالح) من: تقوى، وصلاح؛ وهذا جعله يرى حقيقة الأعمال؛ فربط اليقين بالأعمال، ونزع من قلبه الثك والوسواس(ء)، وكل هذه جعل هن السياقين: الصوفي والسردي متتاغمان.

كما اشتمل المحكيّ على تماسات أخرى مع الخطاب الصوفي في صور تعبيربة متعددة، كما في الفقرة التالية: "أنارت عزة عوش الدار كما أنار الدراويش ساحة المريد، لكن القطب أشاح بوجهه.... وأنا كذللك وكرامة الثيخ ..."(•). في الفقرة السابقة تقاطع الخطاب السردي مع الفكر الصوفي في بعض المصطلحات والمعاني الصوفية المعروفة، مثل: المربد، والقطب، والدراويش، والكرامة، والولي.

(1) ماهر الثيال: منهج الإمام الغزالي في التصوف - مجلة البديل- الجمعة -بr مايو -

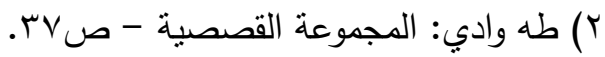

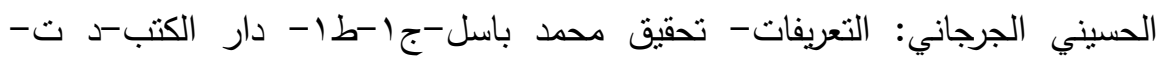

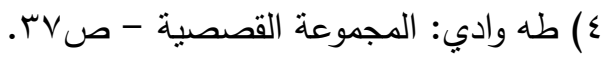

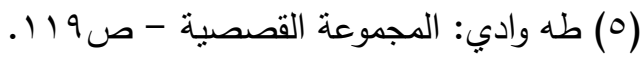


ومن هذا المنطلق يمكن القول بأنّ النص ذاخر بالفكر الصوفي؛ فقد اشتخل

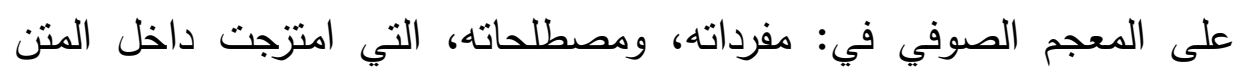
وتلونت بصبغته؛ فانزاحت لمعان جديدة وثوب جميل جذاب.

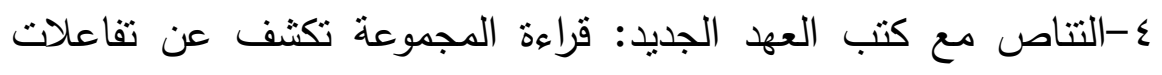

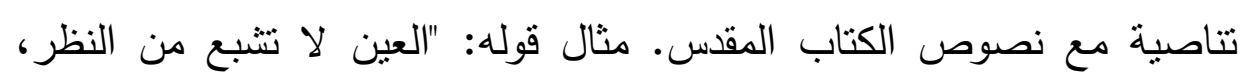

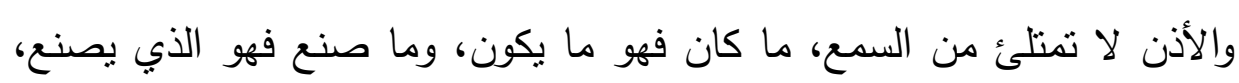

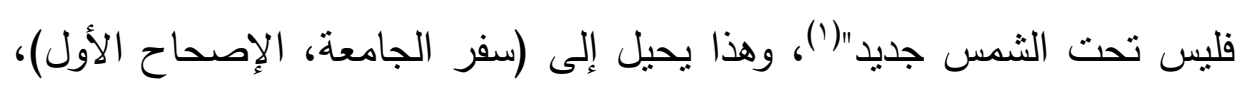

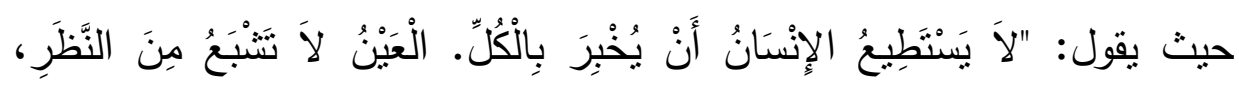

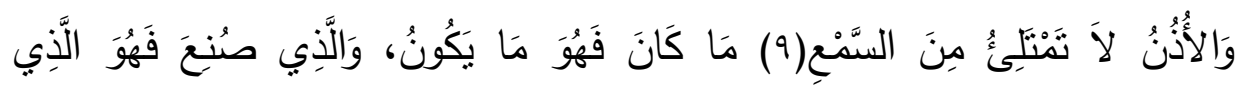

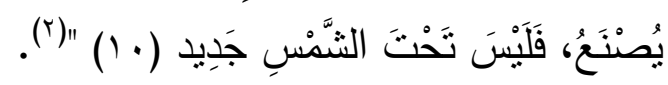

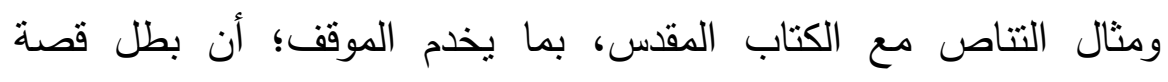

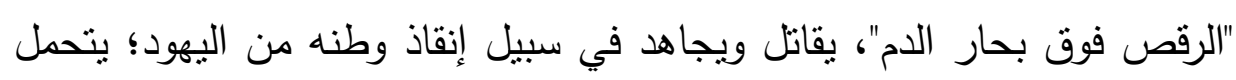

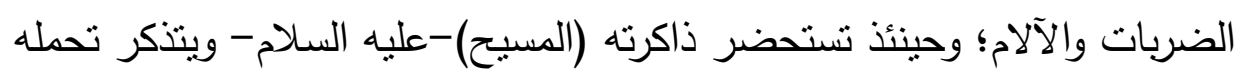

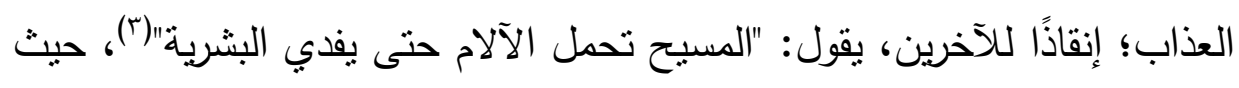

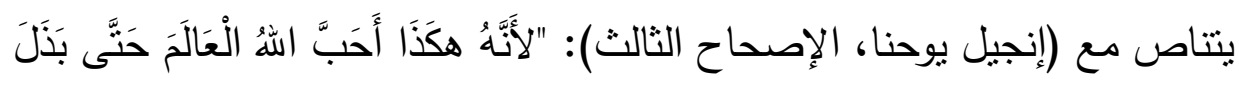

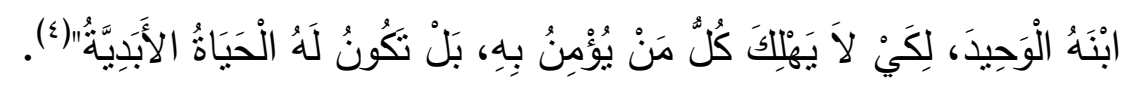

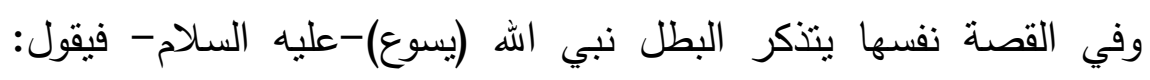
"تقول يا يسوع: من ضربك على خدك الأيسر"(o)، في تناص مباشر مع (إنجيل

$$
\text { (1) (1) طه وادي: المجموعة القصصية - صسّع. }
$$

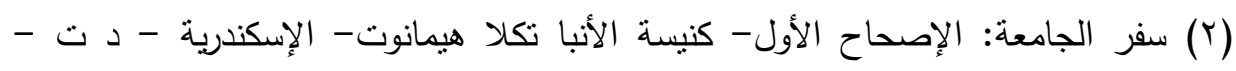

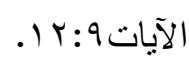

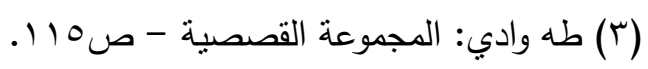

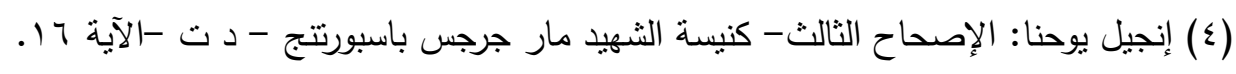

(0) طه وادي: المجموعة القصصية - ص • •11، 111. 


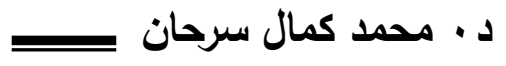

منتى، الإصحاح الخامس): "مَنْ ضَرَبَكَ عَلَى خَدِّكَ فَاعْرِضْ لَلهُ الآخَرَ

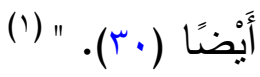

وفي سياق آخر يستعيد البطل موقف المسيح في بلاط (بيلاطس النبطي): "تخيل السيد المسيح من كوة بعيدة. على أرض الناصرة، أخذ (بيلاطس) (يسوع) وجَلَدَه ...(؟). وهذا يتناص-تاريخيَّا- مع ما فعله (بيلاطس النبطي)، القاضي، الذي أصدر الحكم بصلب المسيح؛ تلبية لرغبة اليهود. ويلاحظ توافق وانسجام بين السياقين: السردي والديني؛ فالمسيح يتعرض للظلم والسجن، دون أن ينصره من حوله، والبطل يتخلى عنه الجميع؛ يقول: "تذكر أنّ له إخوة، إخوة عديدين، كثيرين.. يبدو أنهم نسوه أو تتاسوه"(r). وبهذا يتضح ارتباط المحكيّ بالنص المقد، وإعادة صياغته في بنى نصية جديدة؛ مما زاد من: ثراء المتن، وقوة حضوره، وتفاعله مع المتلقي، الذي ينجذب نحو المرويّ، لمتابعة القراءة؛ وصولًا لنقطة النهاية. ه-التتاص مع الثعر القديم: ينابيع الثعر العربي القديم منهل أساس في نص للكاتب؛ فقد نأثر بالكثير من التجارب الشعرية للسابقين، وانعكس صداها في سياقاته السردية، في تفاعل متمازج؛ يعكس وعيًا كبيرًا بالموروث الشعري، مثال ذللك: "لم أعرف لي اسمًا منذ أعلنَّا سياسة الباب المفتوح. أما عمري فقد ضاع،

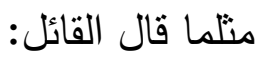

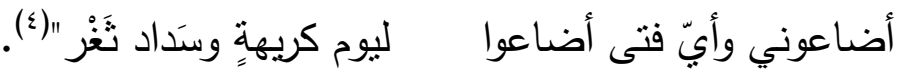

(1) إنجيل منّى: الإصحاح الخامس- كنيسة الأنبا تكلا هيمانوت - الإسكندرية -د ت-

$$
\text { الآيات rV: . r. }
$$

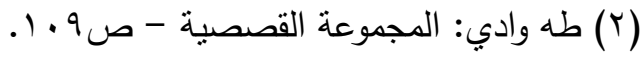

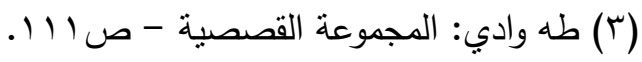

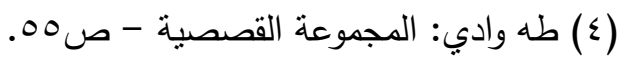




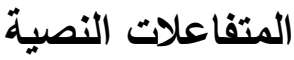

البطل فتى يعيش حالة من الضياع، بسبب ظلم الناس له؛ حيث قبضوا

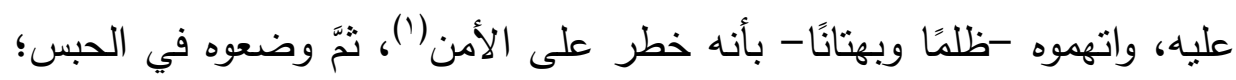

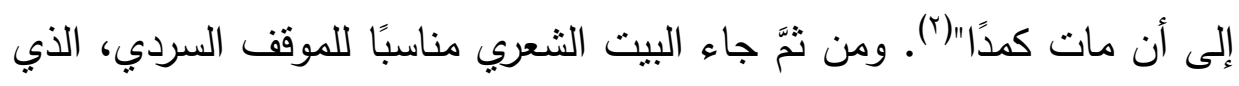
يتماس مع الموروث الأدبي ومع صاحب البيت، الثناعر العربي، الملقب

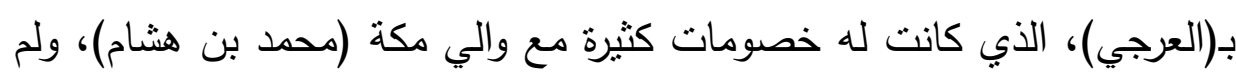

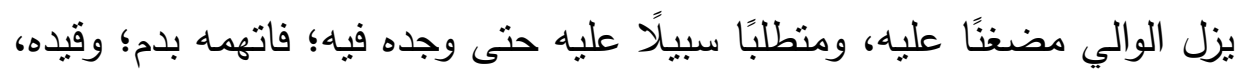

$$
\text { ووضعه في الحبس إلى أن مات. }
$$

وأحيانًا تأتي التعالقات على هيئة: مفردات، وأجزاء من البيت الثعري، منل

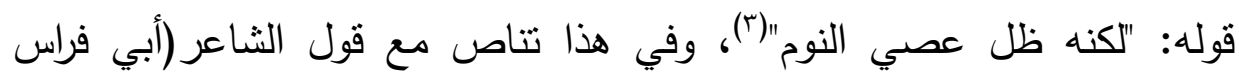

$$
\text { الحمداني): }
$$

أراك عصي الدمع شيمتاك الصبر أما للهوى نهي عليك ولا أمر (\&).

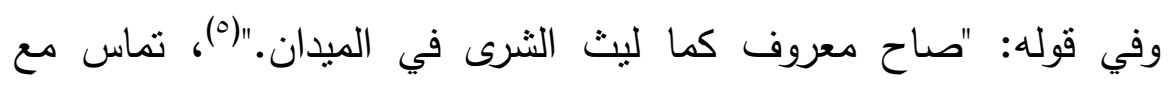

$$
\text { قول(المنتبي)(") }
$$

فاستضحكت ثمّ قالت كالمغيث بُرى ليث الثُرَى وهو من عجل إذا انتسبا ومن نماذج ذللك التتاص؛ ما وقع للبطل، الذي شعر بالضياع، بعد تهدم علاقته

$$
\begin{aligned}
& \text { (1) طه وادي: المجموعة القصصية - صوادي } \\
& \text { (r) طه وادي: المجموعة القصصية - صلادئ. }
\end{aligned}
$$

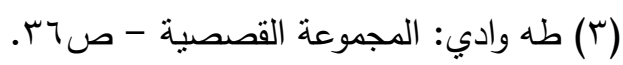

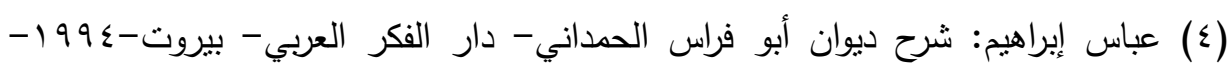

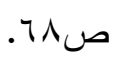

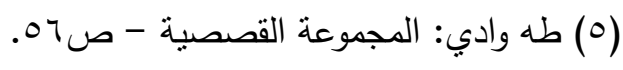

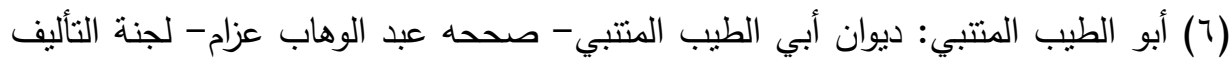

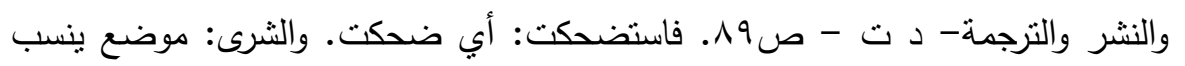

$$
\text { إليه الأسود. }
$$


بمحبوبته: "أحسَّ أنه بعير أجرب، وأنّ الفقر يطارده"(')، ولعل هذا يتتاص

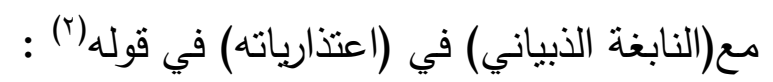

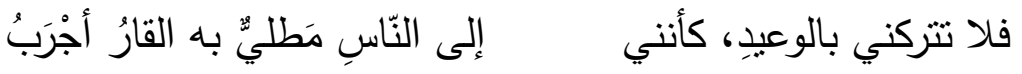

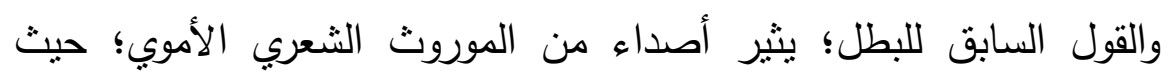

$$
\text { يتعالق مع قول (كُثيّر عزة): }
$$

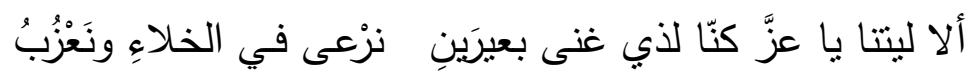

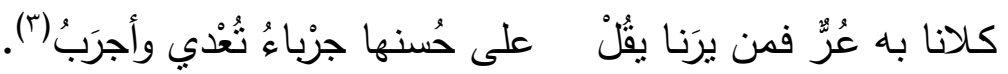

ومن خلال ما سبق يتضح أن الكاتب قد أقام جسورًا متتوعة من الحوار مع

العديد من شعراء العربية في مستويات متعددة، في تتاص حواري شيق؛ مما جعل المقاطع الشعربة تذوب في المنن السردي في صورة فنية، محققة الانسجام والتآلف بين المنظومتين المتتاصنين.

ج- التناص مع التراث السردي: لقد حرص المبدع على استثمار الموروث

السردي في تشكيل قصصه باستلهامه وتوظيفه؛ لتأكيد هوية أمته وتاريخها العريق، وتوثيق عُرَي الروابط بين القديم والحديث، من خلا التماس مع الفنون السردية: ألف ليلة وليلة، والمقامات، والحكايات الثعبية، والأمثنال الثعبية. أ-التناص مع ألف ليلة وليلة: ألف ليلة وليلة من النماذج التراثية التي تأثرت بها نصوص الكاتب، في بنائها المعماري وأسلوب السرد، وظهر ذلك بصورة واضحة في قصة "حكاية معروف الخفير والراعي الفقير" حيث تستلهم أسلوب الليالي في: البناء، والفكرة، والحكي، والثخصيات، مع اختلافين: الأول-

$$
\text { (1) طه وادي: المجموعة القصصية - ص صץ؟1) }
$$

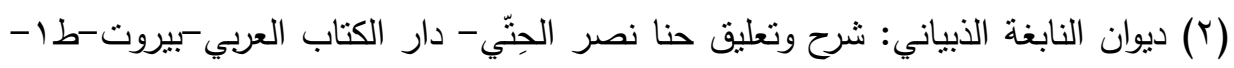

$$
\text { . } r \leqslant ص \text { - 1991 }
$$

(ץ) ديوان كثثر عزة: جمعه وشرحه إحسان عباس- دار الثقافة- بيروت- لبنان - د ت- 
قيام(دنيا زاد) بالحكي بديلًا من أختها(ثهر زاد): "في ليلة من ليالي الخريف

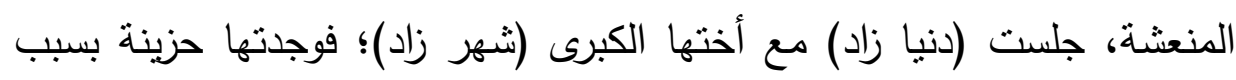

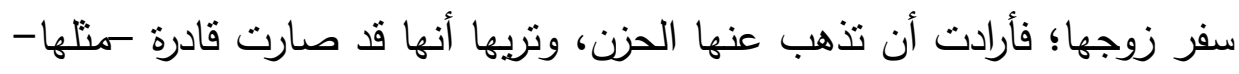

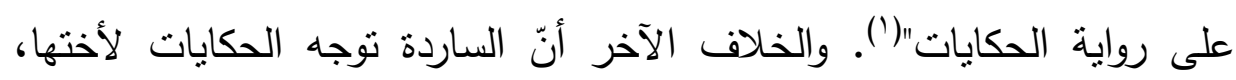

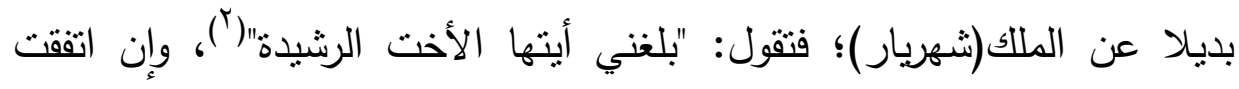

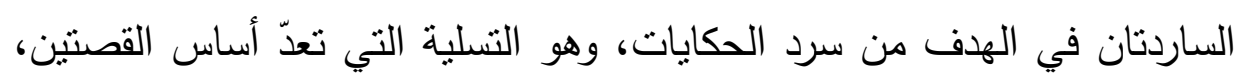

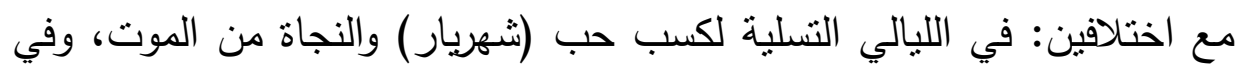
القصة الأخرى التسلية لإزالة الهموم عن الأخت الكبرى.

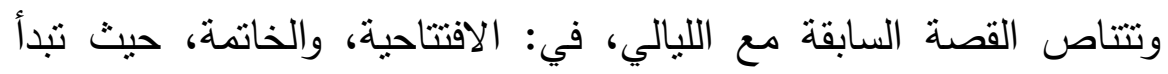

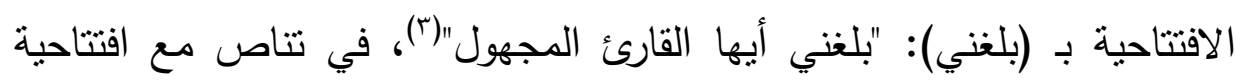

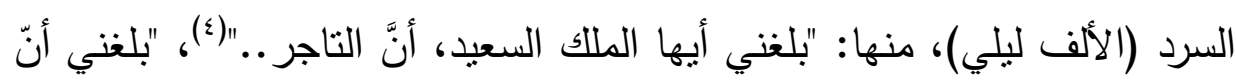

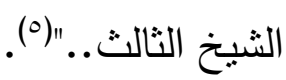
كما يوجد تماس نصي في العتبات النصية؛ فعنوان قصة "حكاية معروف

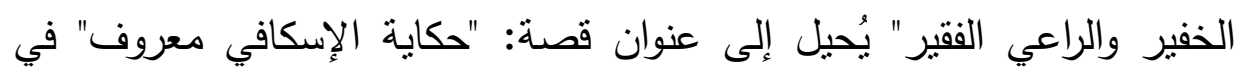

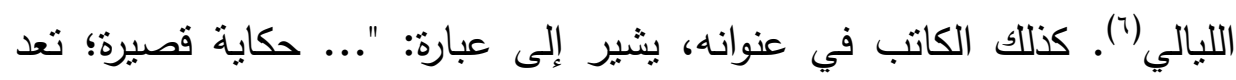

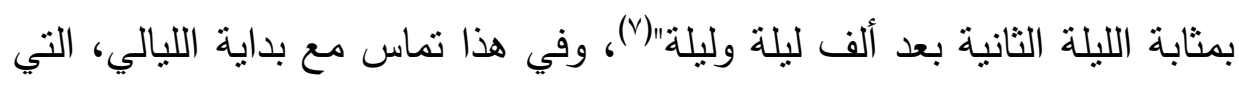

$$
\begin{aligned}
& \text { (1) طه وادي: المجموعة القصصية - صهی ع. }
\end{aligned}
$$

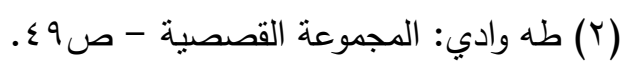

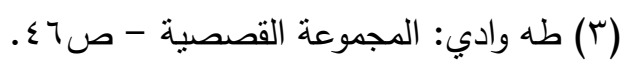

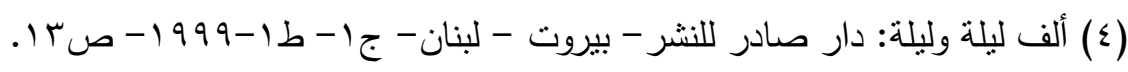

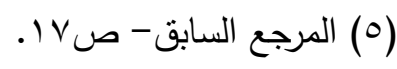

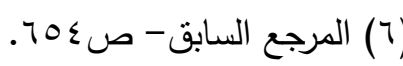

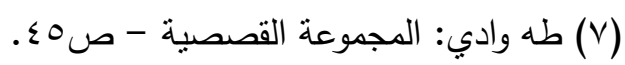

$$
\begin{aligned}
& -7 r \cdot-
\end{aligned}
$$


تشير لرقم كل ليلة في بداية الحكايات، منها: "فلما كانت الليلة الأولى"(')، "فلما كانت الليلة الثانية"(؟). كذلك تتلاقى قصة "حكاية معروف الخفير والراعي الفقير" مع الليالي في الخاتمة؛ حيث تتنهي الأولى بقول الراوي: "وهنا أدرك (دنيا زاد) المساء؛ فكفت عن الحديث"()، في حين تتنهي الليالي بنهايات متقاربة، منل: "وأدرك شهر زاد الصباح؛ فسكتت عن الكلام المباح"(؛ُ). ب-التناص مع فن المقامة: بتتاص الكاتب مع فن المقامة التي فيها ينسب الراوي القصة إلى رواة محددة أسماؤهم، وعلى ألسنتهم بروون ما يشاؤون؛ في محاولة لإيهام القارئ بأنّ الروائي مجرد ناقل للخبر؛ مثال ذلك قول الراوي:

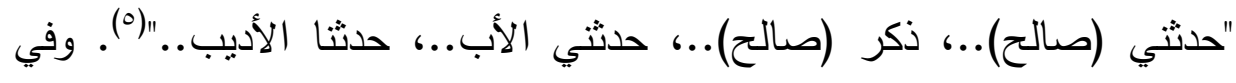
هذا إحالة إلى أسلوب فن المقامة في التراث السردي، التي يمثل فيها الإسناد عنصرًا أساسيًّا كما في مقامات (بديع الزمان الهذذاني)، الذي اتخذ من(عيسى بن هشام) راويًا، يقول في المقامة القريضية: "حدثني عيسى بن هثام؛ قال.."("). والتناص مع المقامة قد يكون في: الثكل، والبناء المعداري، الذي يعتمد على: السجع، والفواصل، والازدواج، مثال ذللك: "أقص للك الليلة حكاية غريبة، ذات أحداث عجيبة، وقعت مع معروف الخفير ، ووحيد الراعي الفقير"(V). وقوله:

$$
\begin{aligned}
& \text { (1) ألف ليلة وليلة: مرجع سابق - صس ا. } \\
& \text { (ץ) المرجع السابق: ص V أ. }
\end{aligned}
$$

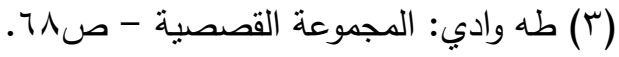

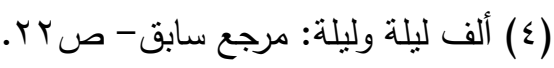

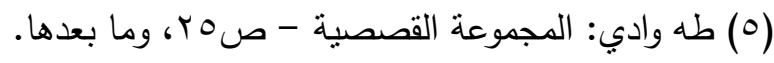

$$
\begin{aligned}
& \text { (T) طه وادي: المجموعة القصصية - ص الجي }
\end{aligned}
$$

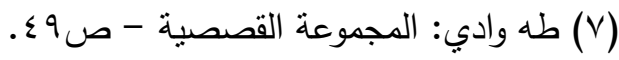


"القانون على الرأس، يا كبير الحراس، ولولا هذا ما جئت إليك، وعرضنا الأمر عليك"(")، وقوله: "هذه با صاحب اللواء، وكاسف الأعداء، وصفة مفيدة"(").

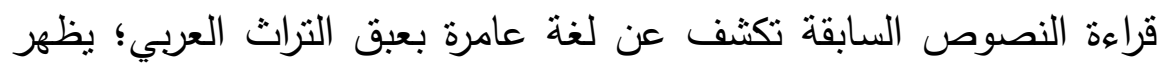

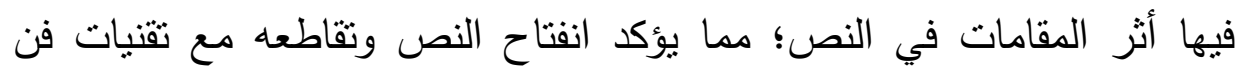

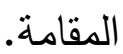
ج- التناص مع الغطبة: تقاطع النص مع بعض السياقات السردية القديمة، ومنها: الخطبة. وقد تأثر الكاتب بخطييين مشهورين، هما: (طارق بن زياد)، و(الحجاج بن يوسف التقفيّ)؛ فقد استلهم من الأول خطبته لجنوده، يقول الراوي: "أحس أنه محاصر من مكان. في التاريخ القديم كان (طارق بن زياد) يقول الاول

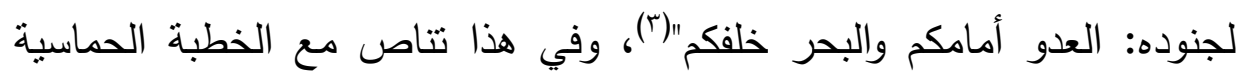

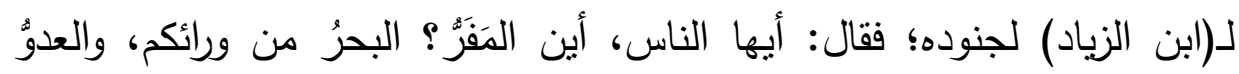

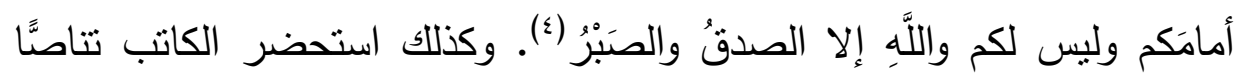

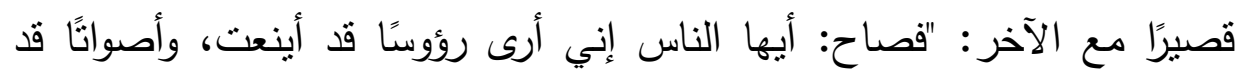

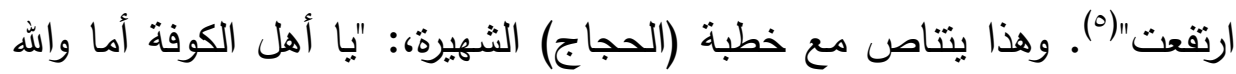

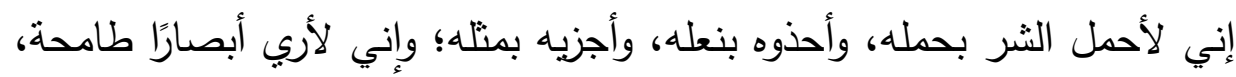

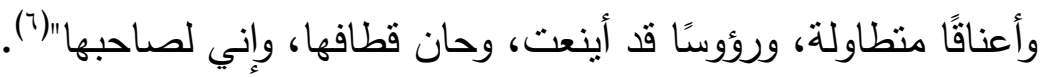

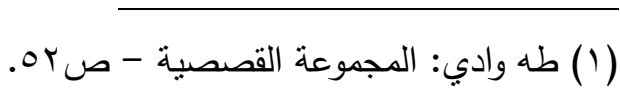

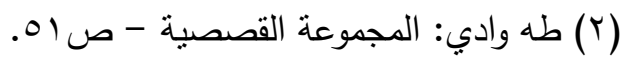

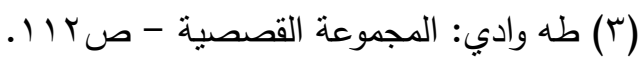

(§) أحمد زكي صفوت: جمهرة خطب العرب في عصور العرب الزاهرة- الدكتبة العلمية-

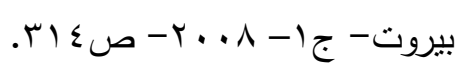

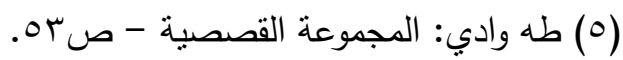

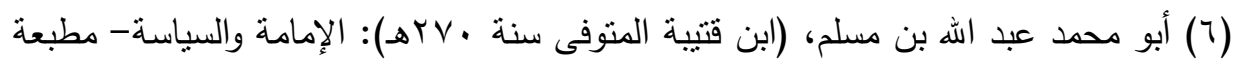

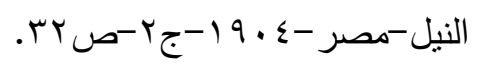




\section{د. · محمد كمال سرحان}

د-التناص مع الأغنية الثعبية: حرص الكاتب على توظيف الأغنية الشعبية في نصوصه؛ لإضفاء أجواء من الروح الشعبية والاجتماعية على متته السردي، مثال ذلك قول البطلة: "عطشانة يا صبايا دلوني على السبيل"(')، وفي لي هذا تماس ضمني مع كلمات (بيرم التونسي): عطنان يا صبايا، عطشان يا مصربين

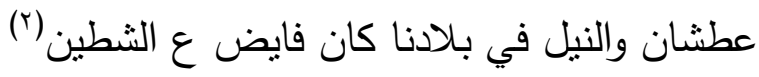

وكذللك تتناص مع كلمات الأغنية المشهورة لـ(مرسي جميل عزيز):عطشانة يا صبايا، دلوني على السبيل. وقراءة النصين: السردي، والغنائي؛ يظهر تمازجًا

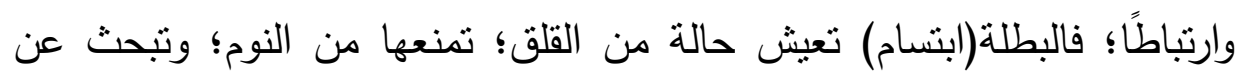
السعادة؛ ولا تجدها؛ فتستحضر الأغنية الثعبية، التي لاقت فيها مرادها وأمنياتها(r)؛ ومن ثمّ جاءت الأغنية الثعبية متسقة مع الموقف منتاغمة مع الثع النص، مشكلة بنية جمالية.

هـ - التناص مع الأسطورة: الأسطورة وليدة: الخيال الإنساني، وفكره، وتجربته، والاتجاه الغالب عليها هو اللامنطق واللامعقول، وتهتم بكل ما يبهر الناس من: خوارق، ومعجزات؛ تجافي الواقع(؛). والأسطورة من الأدوات التعبيرية الجمالية التي استعان بها الكاتب في تشكيل بنية نصوصه؛ لما لها من طاقات كامنة مخزونة؛ تحرك المشاعر الإنسانية، مثال ذلك قول البطلة للنيل: "تمنيت أن تكون أسطورة عروس النيل ما تزال سارية المفعول؛ حتى ألقي بنفسي ونفيسي بين

$$
\text { (1) طه وادي: المجموعة القصصية - ص ابرا. }
$$

(Y) شاكر الحاج مخلف: بيرم التونسي، شاعر الغربة والثورة والحب- جريدة الإعلام الجديدة-

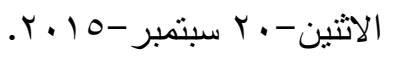

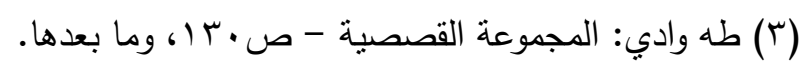

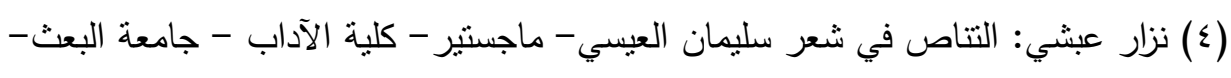




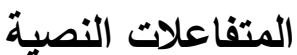

أحضانك"('). فالبطلة فاتها قطار الزواج، وأهلها يحاولون إجبارها على الزواج

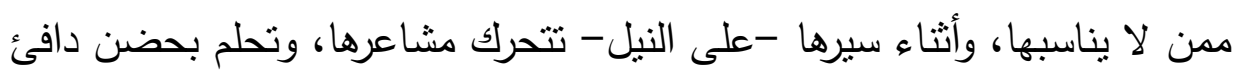
يحتوبها، لكنها تفاجي بأنها وحيدة؛ فتخاطب النيل؛ مستدعية أسطورة عروس لناه النيل. وفي هذا تلاقٍ مع أسطورة عروس النيل عند قدماء المصريين. وتبرز في قصة "حكاية الليل والطريق" تقاطع مع أسطورة (زرقاء اليمامة)

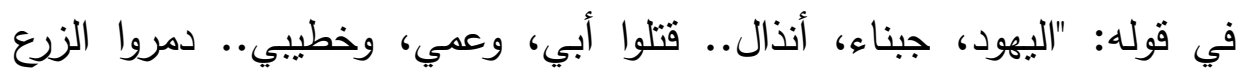
الأخضر ... نورة صبية، ذات عينين حادتي الروية؛؛ متل زرقاء اليمامة" (†).

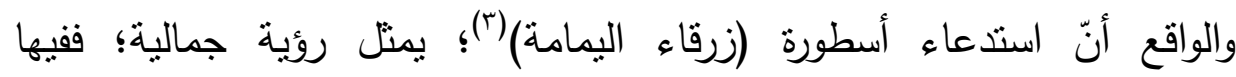
استحضار للبطولة العربية الغائبة؛ فبطلة القصة فلسطينية، لاقت وأهلها الظلم الهاه والمهانة على يد اليهود، وسط صمت عجيب من العرب؛ ومن هنا كان اللجوء

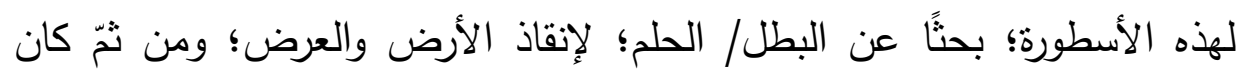

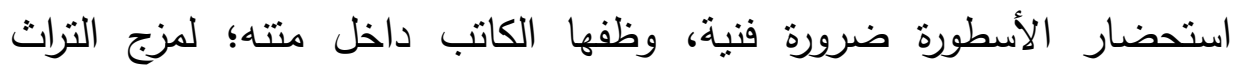
بالحداثة في سياق جديد معبر · و - التناص مع المثل الثعبي: يمنل المثل رافدًا أساسيًا في تتاصات الكاتب؛ حيث شكَّل بنية كبرى في نسيج النص، بما يحتويه من جوانب: فكرية،

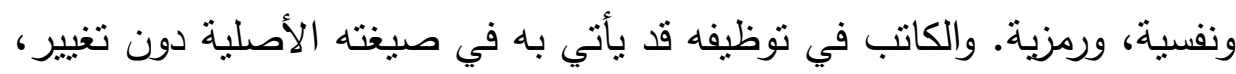

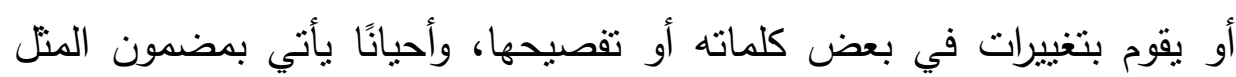

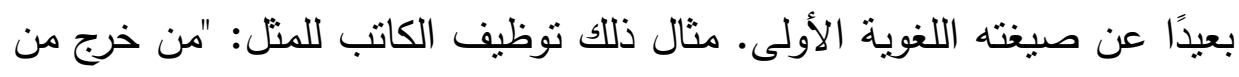

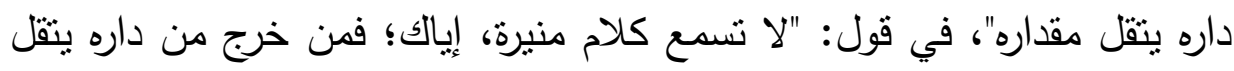

$$
\begin{aligned}
& \text { (1) طه وادي: المجموعة القصصية - صهمبا. }
\end{aligned}
$$

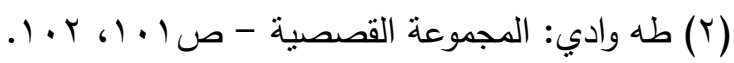

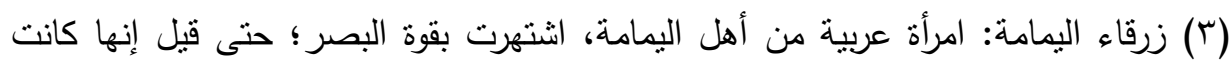
ترى الناس على مسيرة ثلاثة أبام. 


\section{د. · محمد كمال سرحان}

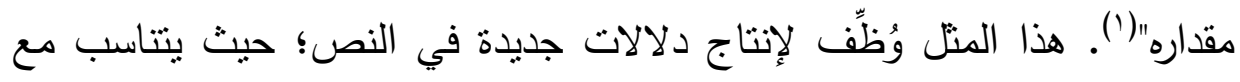

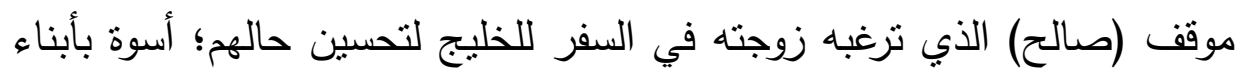
القرية؛ ولكنه يوضح لها أنَّ هؤلاء الذين سافروا هجروا بيوتهم، وقصروا في حقوق لئه

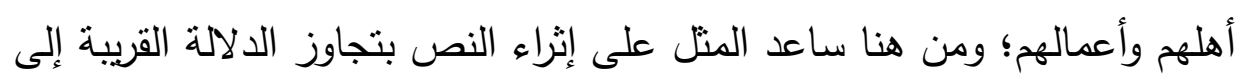

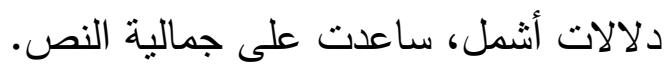
كما وظّف الكاتب المنل الثعبي: "اللي إيده في الميه مش زئل زي اللي إيده في

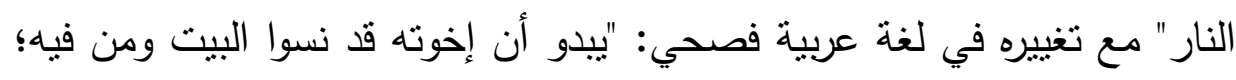

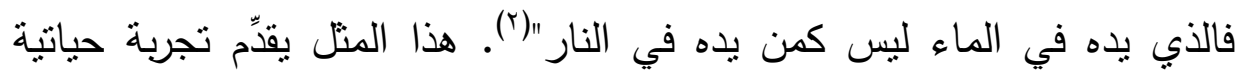

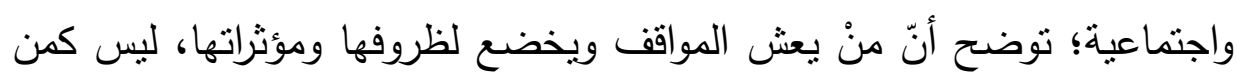
هو خارجها، وهذا يتتاسب مع (عبد الله) الذي يشعر بالضيق؛ لأن بيت العيت العائلة

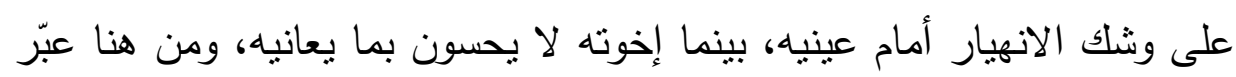
المنل عن التجربة والموقف في صورة فنية جذابة.

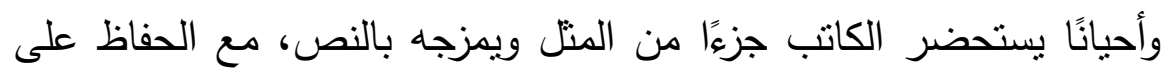

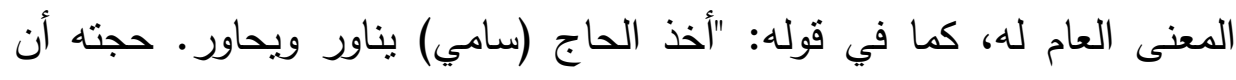

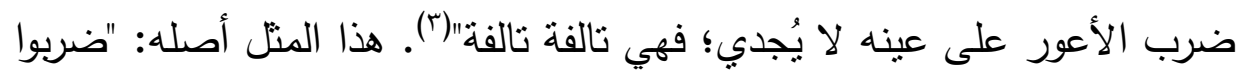

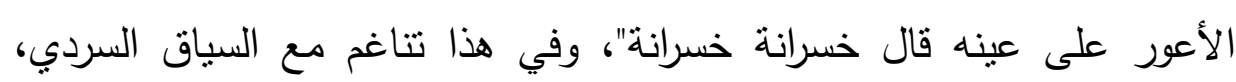

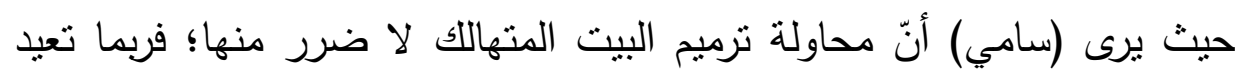

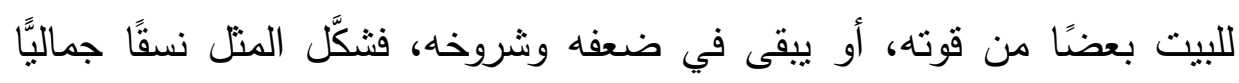

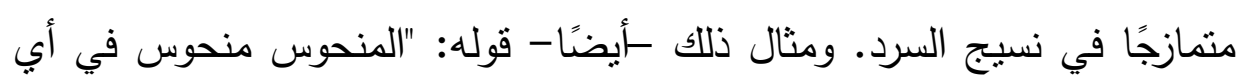
مكان"(())، يتماس مع المتل: "المنحوس منحوس ولو علقوا في رأسه فانوس".

$$
\begin{aligned}
& \text { ( () طه وادي: المجموعة القصصية - صع ؟r. }
\end{aligned}
$$

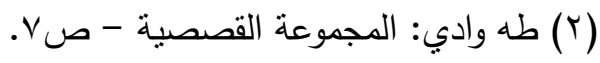

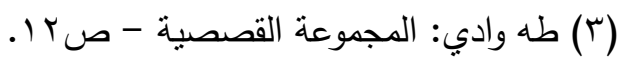

$$
\begin{aligned}
& \text { ( ) طه وادي: المجموعة القصصية - صدیז. }
\end{aligned}
$$




\section{المتفاعلات النصية}

وقد يأتي الكاتب بمضمون المثل، ويمزجه في متته، والقارئ يستتبط المتل

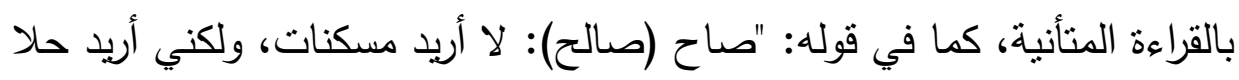

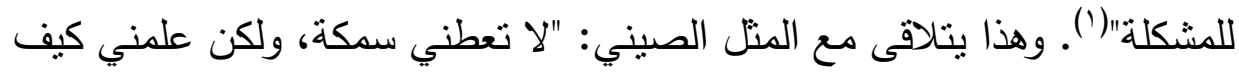

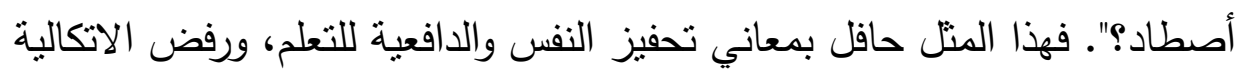
على الآخرين؛ وهذا ما يعبر عنه النص. فئل مما سبق يتضح الدور الفني لاستلهام الكاتب للمتل الثنعبي في تشكيل

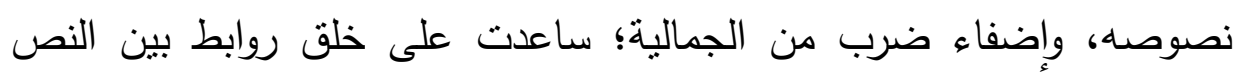
والذاكرة الجمعية للشعب.

ثانيًا-مستويات التناص: لرصد جماليات النتاص يلزم تحديد النص لئل المتتاص، وربطه بأصوله وجذوره التي امتد منها. ومن خلا له القراءة المتأنية

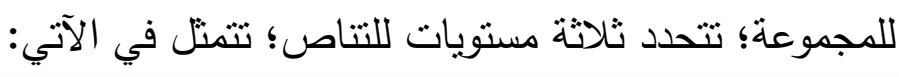

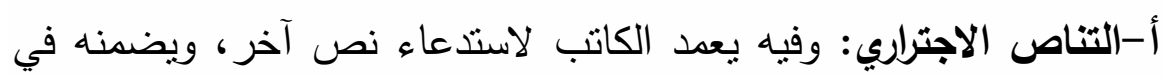

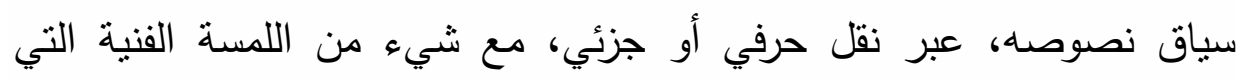

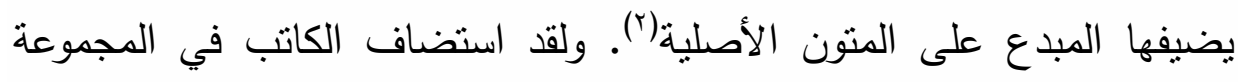
نصوصيًا خارجية، ووضعها في السياق السردي دون مساس أو تغيير . كما في

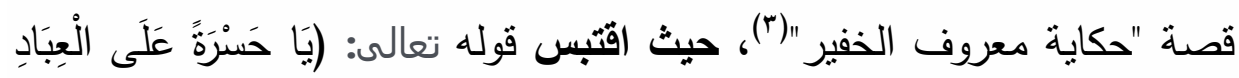

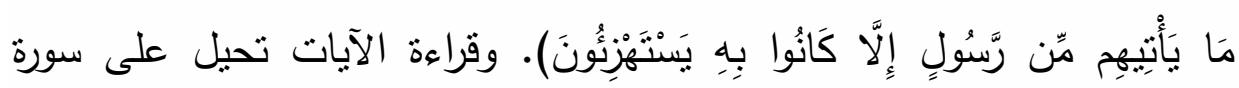

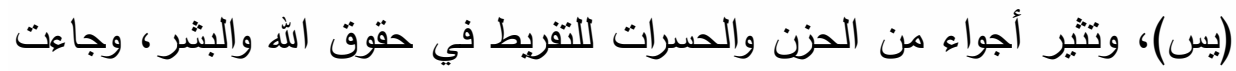
البنية القرآنية متتاغمة مع دلالات النص، الذي يتتاول ظلم البشر لغيرهم؛ غافلين

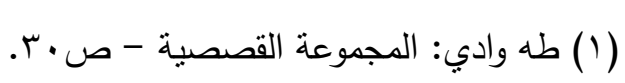

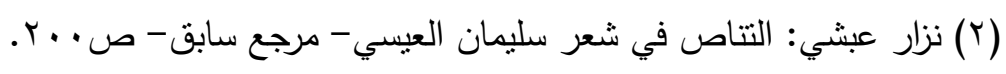

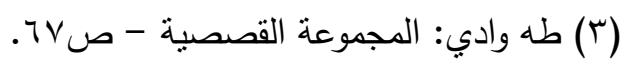




\section{د. - محمد كمال سرحان}

عدل الله، لكن أفعالهم هذه سنكون حسرة ووبالًا عليهم في الدنيا والآخرة؛ فاستحضار النص القرآني زاد من ثراء الدلالة النصية في صورة جمالية جديدة. ومن التتاصات الجيدة -في باب الاجترار - قوله: "تطاولت الأيدي، تريد جذبه، والاعتداء على قدره، مع أن الله سبحانه، يقول: (فلا عدوان إلا على الظالمين)"(1)، يستدعي الكاتب الآية الكريمة؛ ليكثف مدى الخطأ الذي وقع فيه القوم بظلمهم للراعي، واعتدائهم عليه دون ذنب ارتكبه(؟). أما في تتاصه الاجتراري مع الحديث الثربف؛ فجاء في أكثز من موضع، منها: عندما شاهد البطل فتاة جميلة؛ يستحضر : "الله جميل يحب الجمال"(َ)؛ اقتباساً من حديث الرسول عليولسلهم : "لا يدخل الجنة من كان في قلبه مثقال ذرة من كبر؛ قال رجل: إن الرجل يحب أن يكون ثوبه حسنًا ونعله حسنًا قال: إن اله جميل يحب الجمال)( (؛). وقوله: "فلا تحاول الخديعة، وتذكر أن الرسول الكريم يقول:(من غشنا فليس

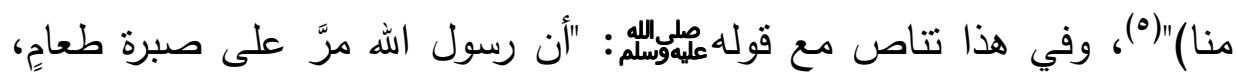
فأدخل يده فيها، فنالت أصابعه بللًا، فقال: ما هذا يا صاحب الطعام؟ ، قال: أصابته السماء يا رسول اله! قال: أفلا جعلته فوق الطعام كي يراه الناس، من

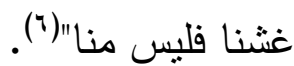

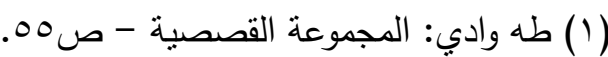

$$
\begin{aligned}
& \text { (Y) طه وادي: الدجموعة القصصية - الصفحة نفسها. }
\end{aligned}
$$

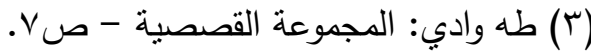

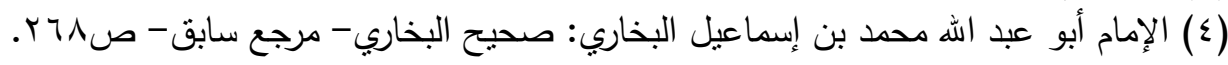

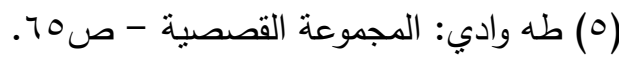

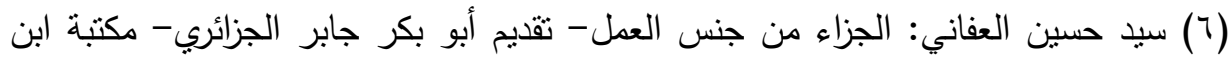




\section{المتفاعلات النصية}

ويتتاص الكاتب -تناصًّا اجتراريًّا- مع أبيات من الثعر القديم في قوله:

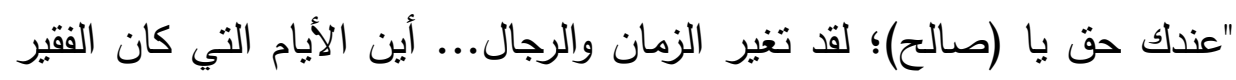

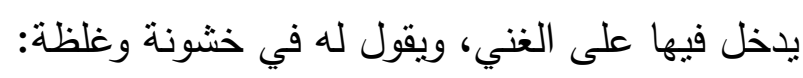

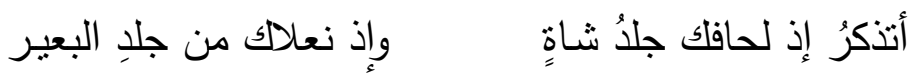

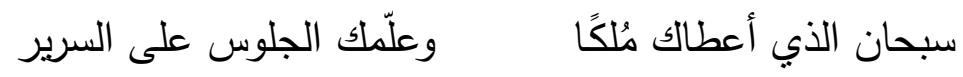

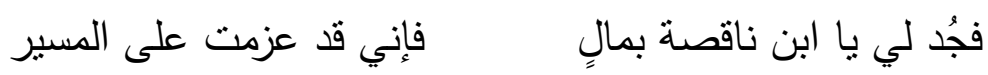

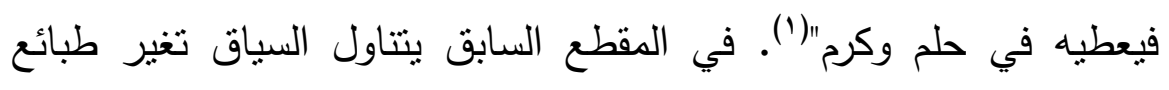

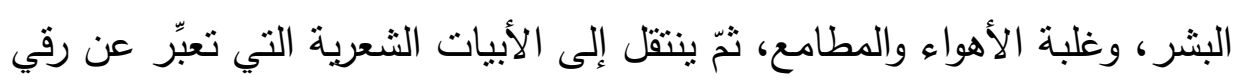

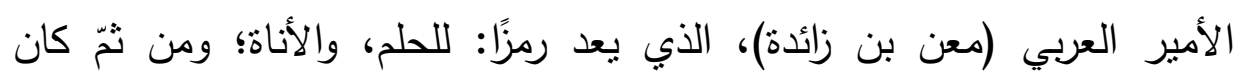
استحضار الثعر العربي مناسبًا في السياق السردي.

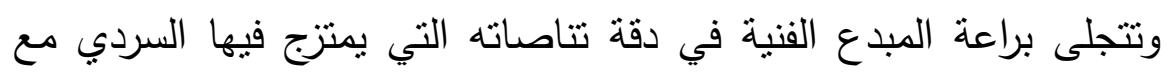

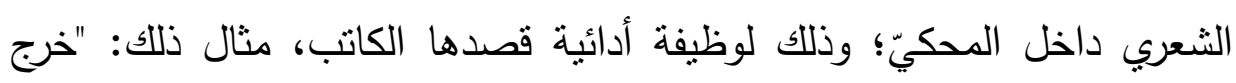
معروف من داره، سجين أفكاره؛ يلعن زوجته، التي عاملها بكل مليح؛ فقابلته بالقبيح، وأخذ يتمنل قول القائل الفصيح:

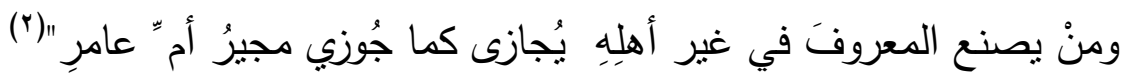

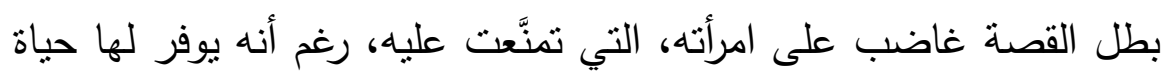

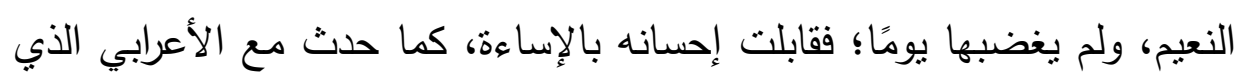

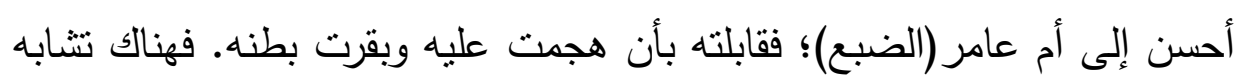

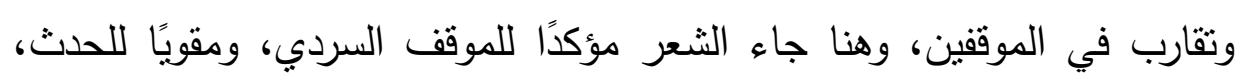
ومؤيدًا لانفعالات الثخصيات.

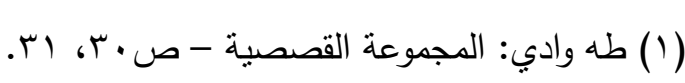

$$
\begin{aligned}
& \text { (r) طه وادي: الدجموعة القصصية - ص.0.0. } \\
& -7 r \Lambda-
\end{aligned}
$$




\section{د. . محمد كمال سرحان}

ومن قراءة ما سبق يتضح أن الكاتب استخدم آلية التناص الاجتراري؛ باستحضار النصوص دون أن يُجري تغييرات فيها؛ مما جعل هذه الاسنتهادات تمثل جانب قوة داخل النص السردي؛ حيث جاءت متتاغمة مع النص، متلائمة

$$
\text { مع الموقف، بعيدة عن الحشو والحوشي. }
$$

ب-التناص الامتصاصي: هذا النوع من التتاص أكثر تطورًا من سابقه؛ حيث يشكّله الكاتب، ويعيد صياغته وفق الموقف والسياق النصي، وفيه "لا يعلن عن وجود ملفوظ حرفي مأخوذ من نص آخر، ومندرج في بنيته بشكل صريح، كلي ومعلن، وإنما يشير إليه، ويحيل الذاكرة عليه، عن طريق وجود دال من

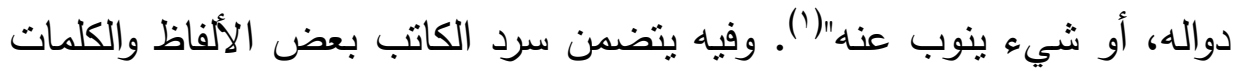
التي تتشير إلى النص المقتبس؛ مما يترك الباب مفتوحًا أمام المتلقي لتعدد

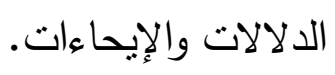

ويوظف الكاتب القرآن الكريم في نصوصه -من خلال التناص الامتصاصي- لدلالات إيحائية جديدة، مثال قوله: "إنّ أكل اللحم سوف يفرق بين: الأخ، وأخيه، والأب وبنيه، والرجل وزوجه، ويجعل الناس سكارى وما هم

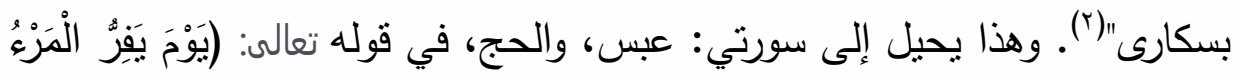

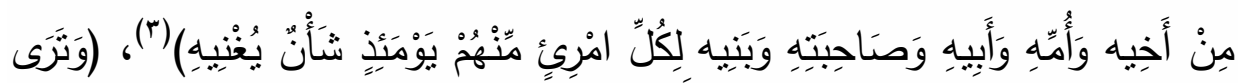

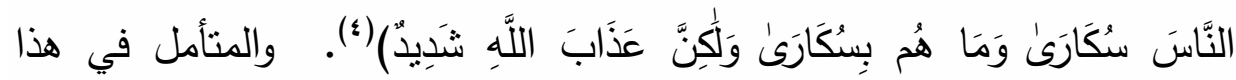
التفاعل النصي يجد أن الكاتب أتي ببعض الكلمات التي تحيل المتلقي بسهولة

(1) عصام حفظ الله واصل: التتاص التراثي في الثعر المعاصر - دار غيداء للنشر -عمان-

$$
\text { ط מ } 90
$$

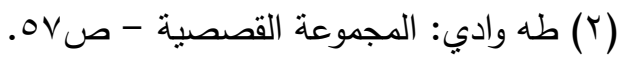


للآيات الكريمة، مع العناية بتوافق وانسجام السياقين في التعبير عن حالة الفزع، التي تنزعج لها الأفئدة.

ومن التناص الامتصاصي مع القرآن الكريم قوله: "عاد (صالح)، وجد منيرة

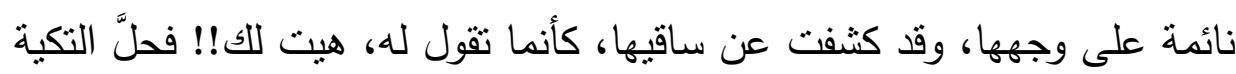
الصوفية، وتوكل على الله يؤتي حرثه"('). هذا الدقطع السردي يفتح بابًا للإحالة

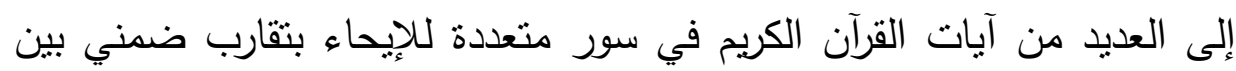

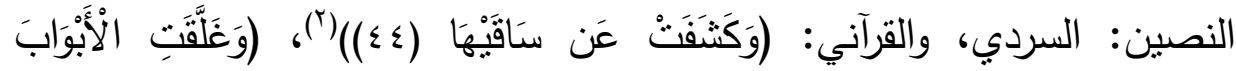

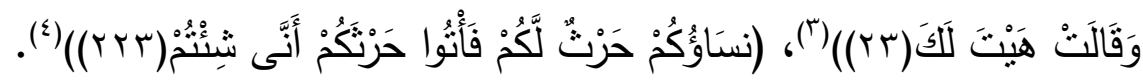

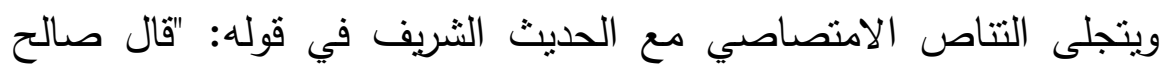

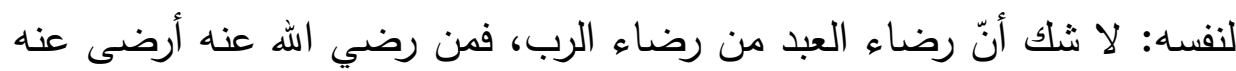

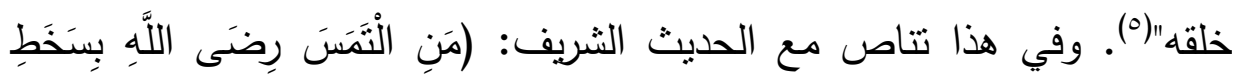

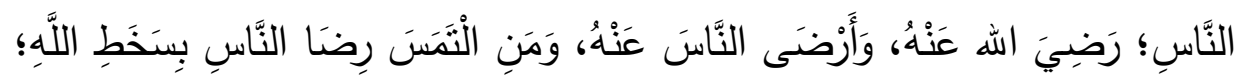

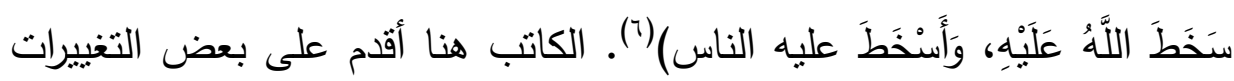
في الحديث، دون تغيير الجوهر الذي يرشد المتلقي للنص الأصلي.

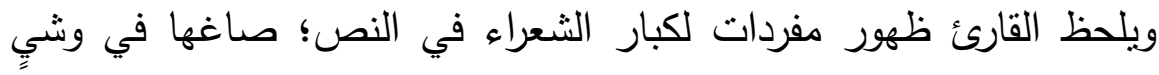
خاصّ معبر عن السياق السردي، بعد أن أفاض عليها من: مشاعره، ومخزونه

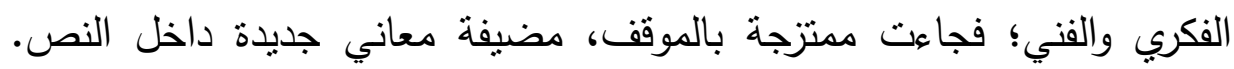

$$
\begin{aligned}
& \text { (1) طه وادي: المجموعة القصصية - صع ז. }
\end{aligned}
$$

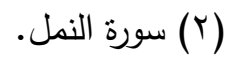

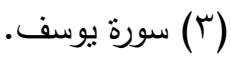

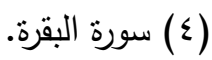

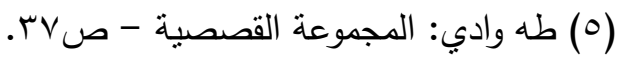

$$
\begin{aligned}
& \text { (T) السيوطي والألباني: مختصر صحيح الجامع الصغير - أعده أحمد نصر اله صبري- ألفا }
\end{aligned}
$$

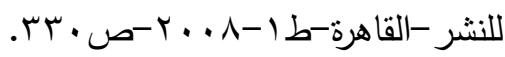




\section{د. - دممد كمال سرحان}

مثال ذللك قوله: "قولوا معي: هل رأى الحب سكارى منلنا؟ فردوا عليه: سكارى منلنا.. سكارى منلنا"('). وفي هذا تتاص مع قصيدة (الوداع) للشاعر (إبراهيم ناجي)، حيث يقول:

هل رأى الحبٌّ سكارى منتلا؟! كم بنينا من خيالٍ حولنا!(؟) ومثال التتاص الامتصاصي في صورة مفردات مجتزئة من البيت الشعري، مع تغييرات قليلة في التركيب، قوله: "ظل عصي النوم"(")، وفي هذا تتماس مع قول(أبي فراس الحمداني):

أراك عصي الدمع شيمنلك الصبر أما للهوى نهي عليك ولا أمر (ء). وقد يأخذ الكاتب مضمون كلامه من الثعر العربي القديم، مع الإشارة الواضحة إلى أنه يتتاص معه، كما في قوله: "طالت الليالي، وامتدت الأيام"(ه). الكاتب هنا ينبه المتلقي بأن هذا المعنى ليس وليد فكره، وإنما له أصل في الشعر القديم في قول (أبي نواس):

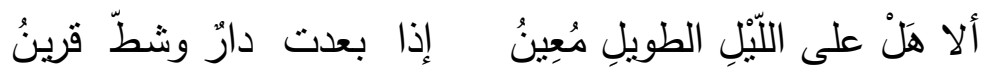

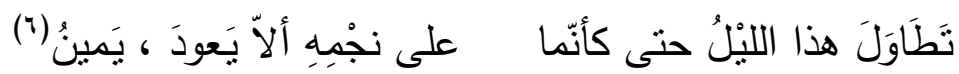

وقول البطل "يحلمان بالهجرة إلى الخارج عن طريق أي وسيلة .. لاحب .. ولا سكن.."(v). وهذا يتكئ على (قول المتتبي):

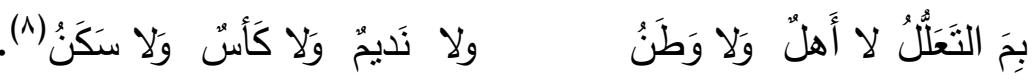

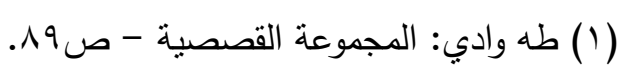

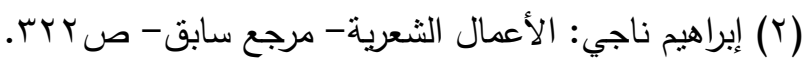

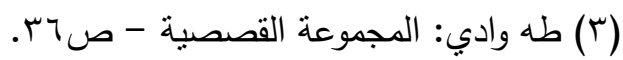

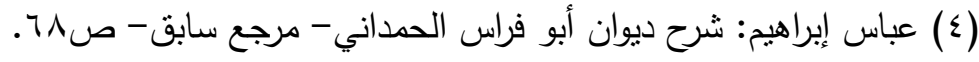

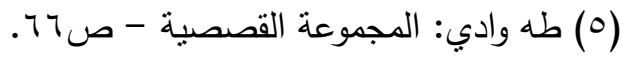

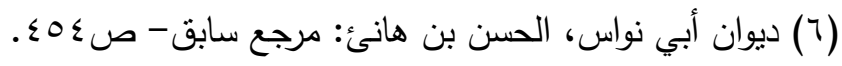

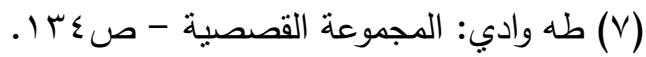

$$
\begin{aligned}
& \text { (^) ديوان أبي الطيب المنتبي بشرح أبي البقاء العكبري- مرجع سابق - صهـr (V) }
\end{aligned}
$$


وبهذا يتضح أنّ الكاتب أبدع في الاقتباس الامتصاصي؛ حيث ينوارى النص

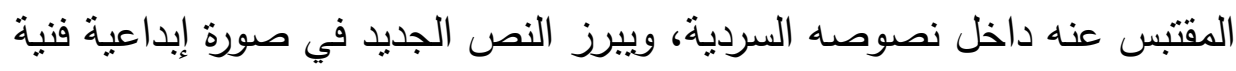

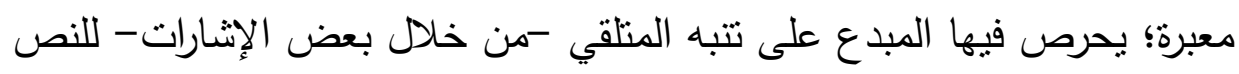
المقتبس؛ مما يكثف فنية الكاتب في تذويب النص الغائب في سياق المحكيّ.

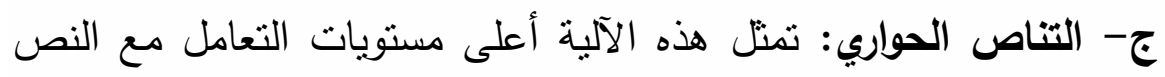

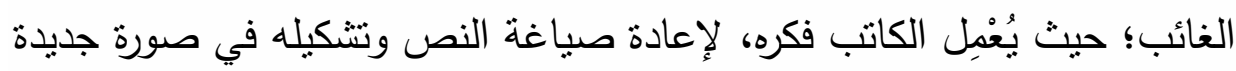

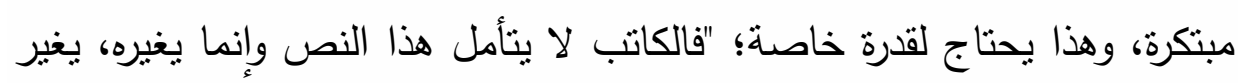

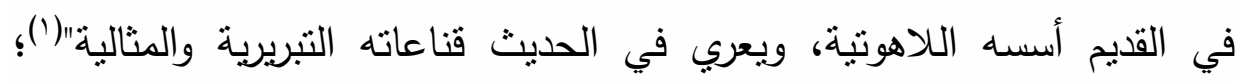

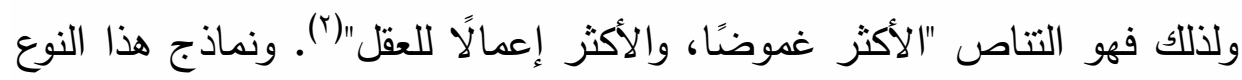

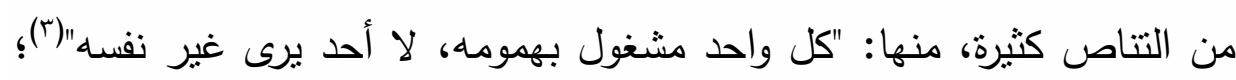

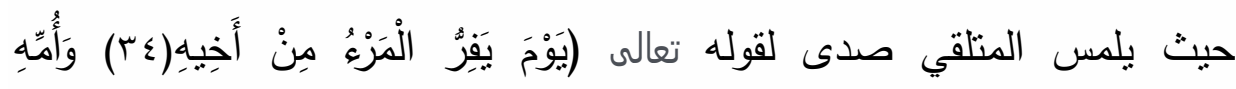

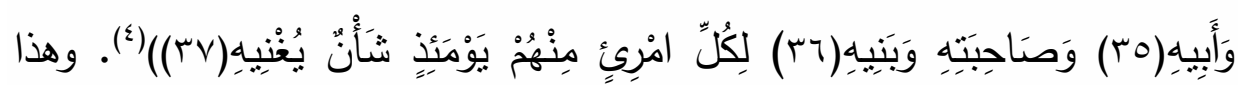

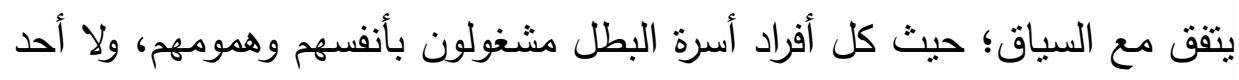
فيهم يفكر إلا في مصلحته الخاصة فقط، وكأنهم في يوم القيامة.

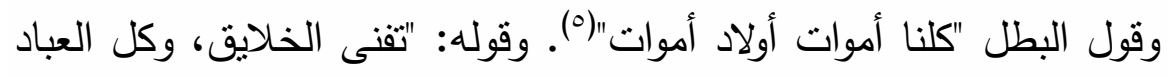

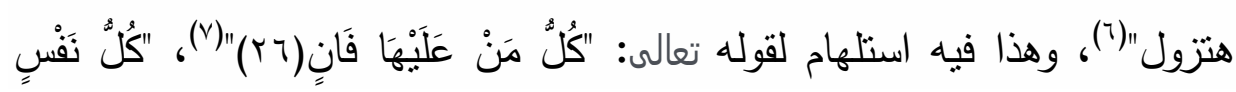

(1) محمد نبيس: ظاهرة الثعر المعاصر في المغرب، مقاربة بنيوية تكوينية-دار توبقال

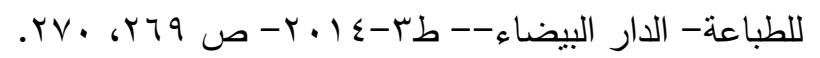

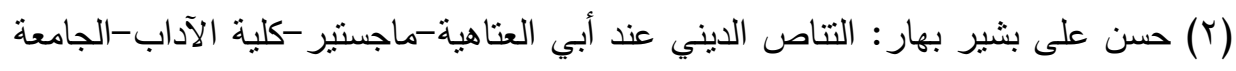

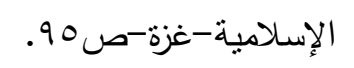

(ץ) طه وادي: الدجموعة القصصية - صؤه 9.

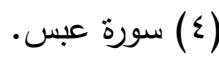

(1) طه وادي: الدجموعة القصصية - صمبرا.

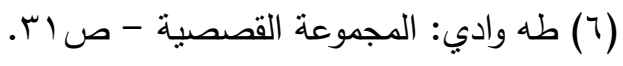

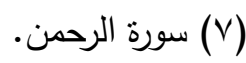




\section{د. · محمد كمال سرحان}

ذَائقَةُةُ الْمَوْتِ(10)(1)"(). وقول الراوي: "الأطباء ينصحونه بعدم التذخين، وهم

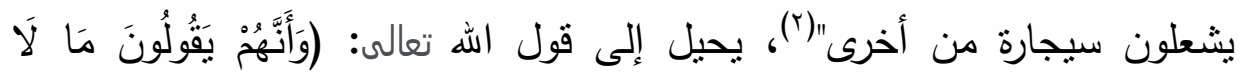

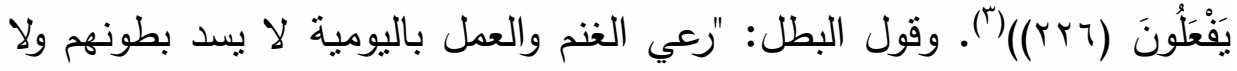

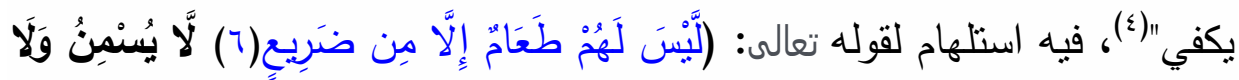
يُفْنِي مِن جُوعِ(())

ومثال التتاص الحواري مع الحديث الثريف: "لم يسمع الكلام، وركب رأسه، وهذه عاقبة من لا يعجبه إلا رأسه؛ يغرق ويغرق كل من معه، لا فائدة من الكلام

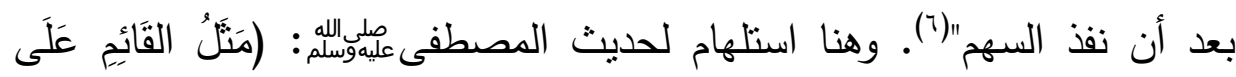

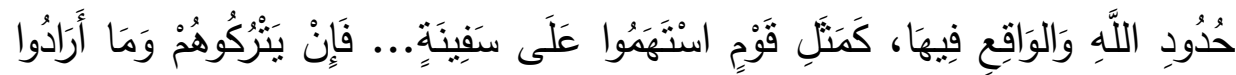

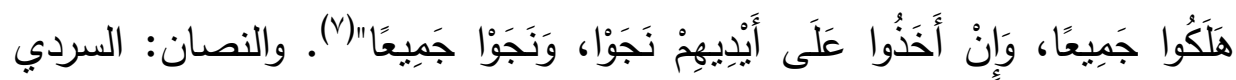
والنبوي يتماسان في الإشارة إلى أهمية إقامة الحدود، التي بها يَحصل النجاة لمن أقامها، وإلا هلك: العاصي بالمعصية، والساكت بالرضا بها. ولقد أجاد الكاتب في تتاصه الحواري مع الثعر العربي: قديمه وحديثه. مثال

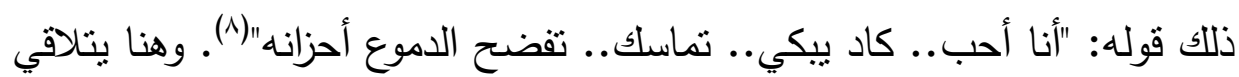
مع قول (المتتبي):

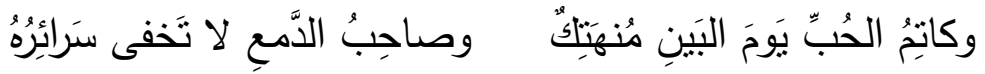

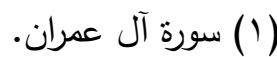

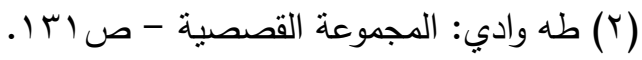

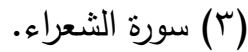

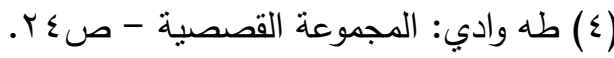

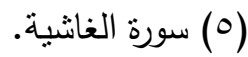

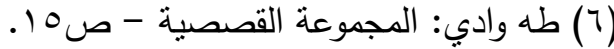

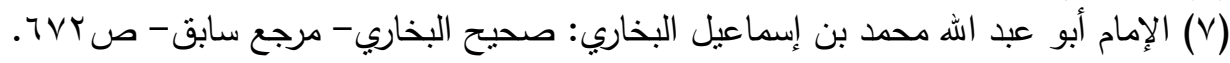

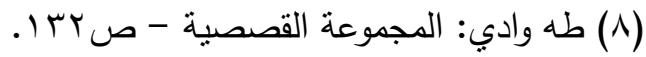

$$
\begin{aligned}
& \text { - trut }
\end{aligned}
$$


والنصان متفقان في التلميح إلى أن الذي يكتم حبه؛ حتى لا يُفنْضَح أمره بين

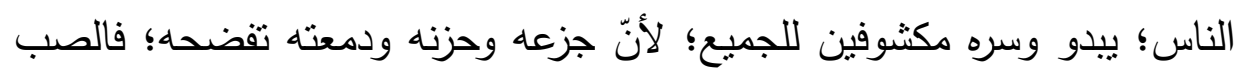
تفضحه عيون.

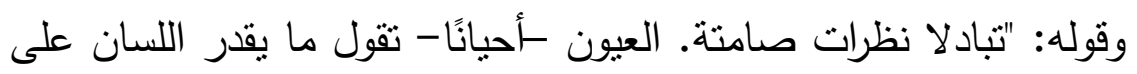

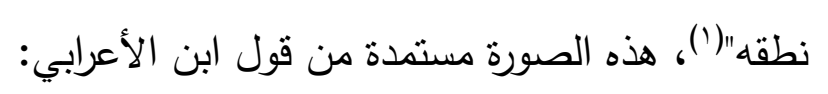

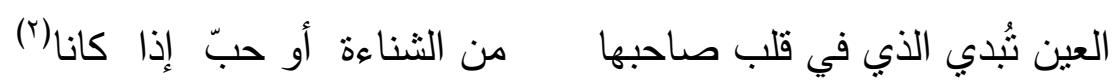

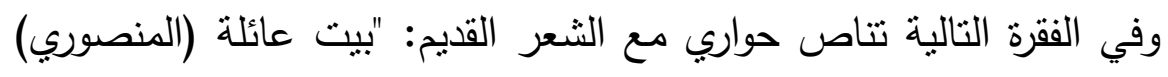

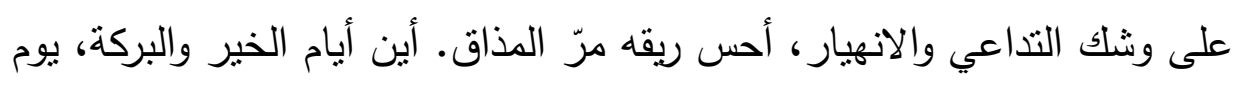

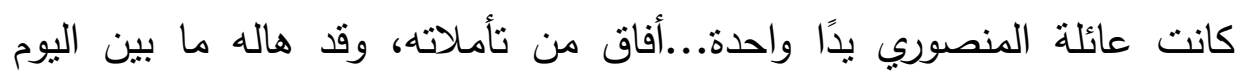
والأمس"("). وفي هذا إحالة لقول (أسامة بن منقذ):

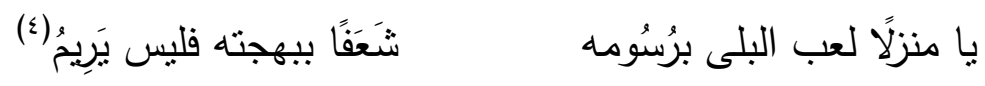

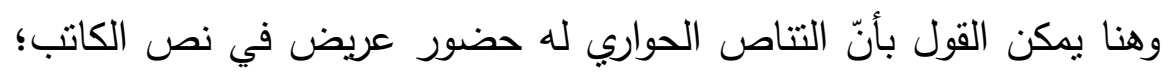

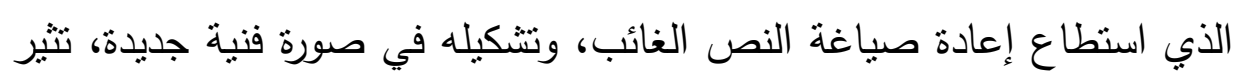
ذهن المتلقي، وتدفعه للبحث عن الرابطة بين النص الحالي والنص المتناص

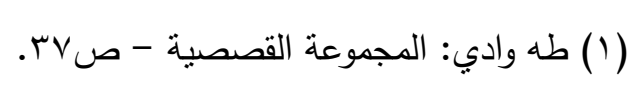

(ץ) محد الثيخ: كتاب الحكمة العربية، دليل التراث العربي إلى العالمية- الثبكة العربية العبية

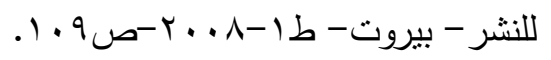

$$
\begin{aligned}
& \text { (ץ) طه وادي: المجموعة القصصية - صلآ، وما بعدها. }
\end{aligned}
$$

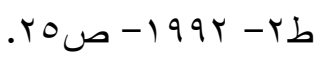

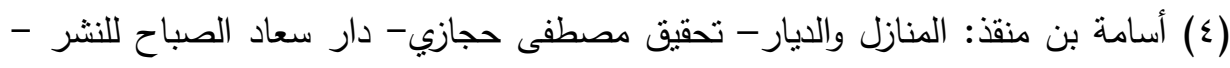




\section{الخاتمة:}

سعى البحث إلى الوقوف على دراسة التتاص في مجموعة "حكاية الليل

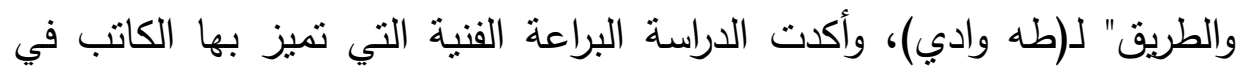

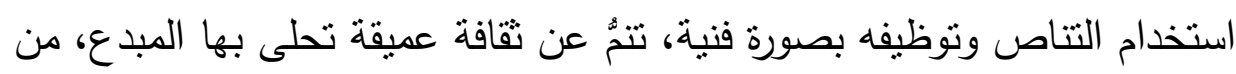

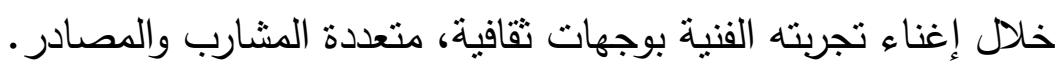
ولقد تعددت أثنكال التتاص داخل المجموعة؛ فنشملت: الذاتي، والداخلي، والخارجي.

التناص الذاتي اتضح بالكثف عن العلاقات التي تقيمها نصوص الكاتب بعضها ببعض، وتمثّل في بعض الظواهر الأسلوبية ذات الأبعاد الفنية والدلالية؛

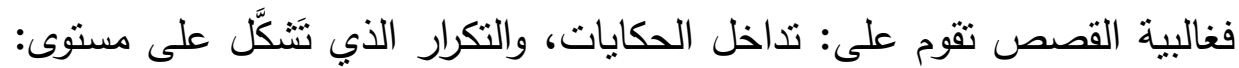

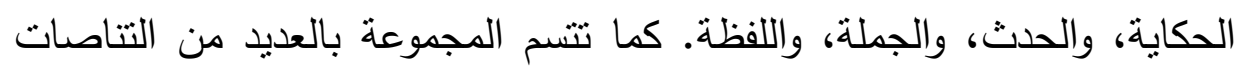

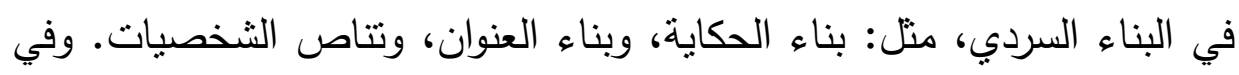

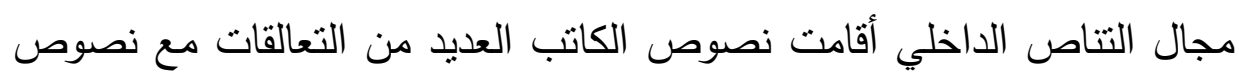

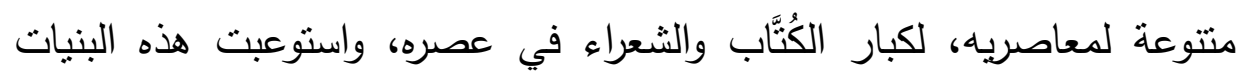

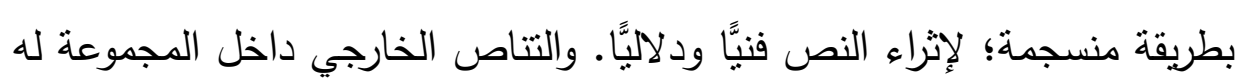

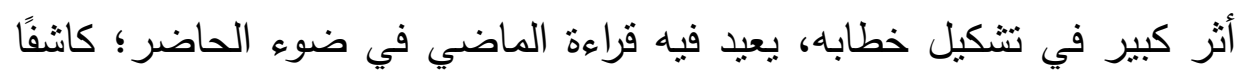

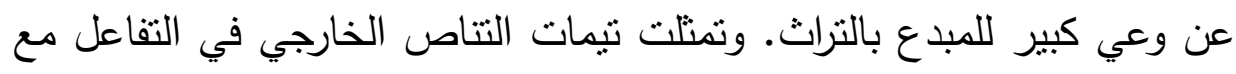

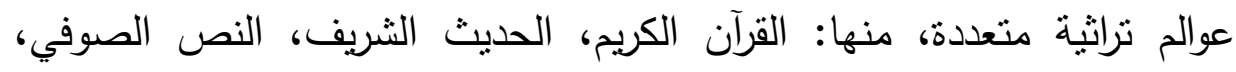
نصوص العهد الجديد، الثعر العربي القديم، التراث السردي.

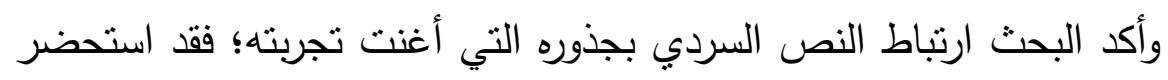
الكاتب النصوص الغائبة داخل إبداعاته المختلفة في ثلاثة مستويات، التتاص: الاجتراري، والامتصاصي، والحواري. 


\section{المتفاعلات النصية}

ظهر التتاص الاجتراري في المجموعة باستدعاء نصوص الغير في سياقه

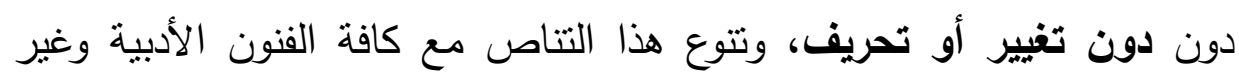

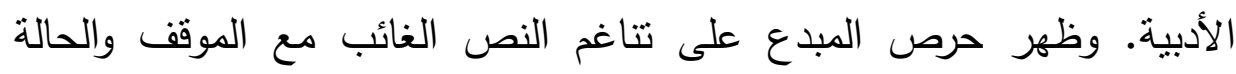

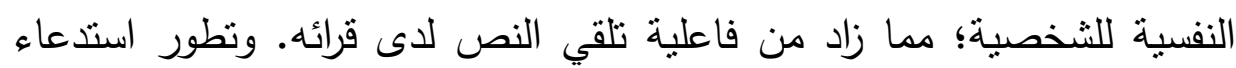

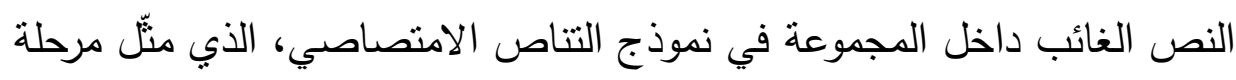

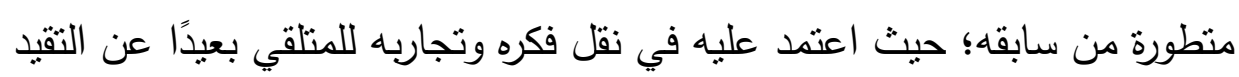

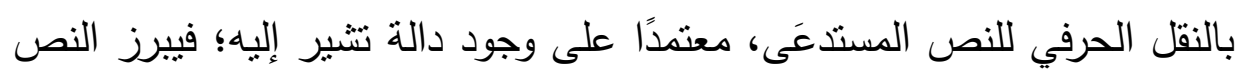

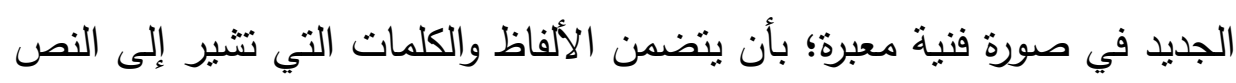
المقتبس.

وكثفت المجموعة القصصية عن مستوى أعلى في التماس مع نصوص الغير؛ تمثلت في التتاص الحواري، الذي يقوم على كسر التقاليد المعهودة،

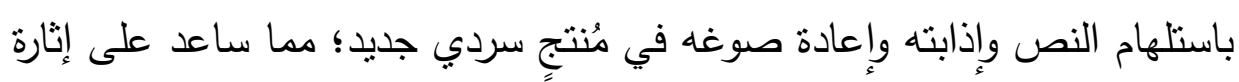

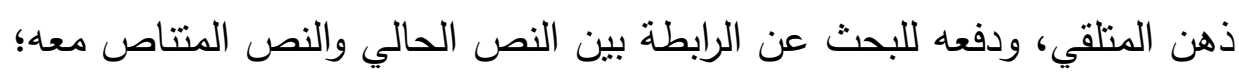

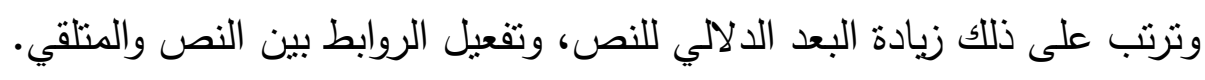

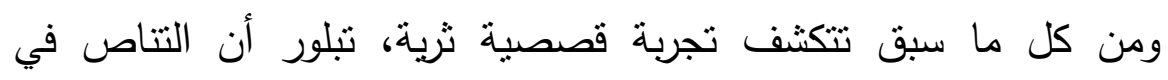

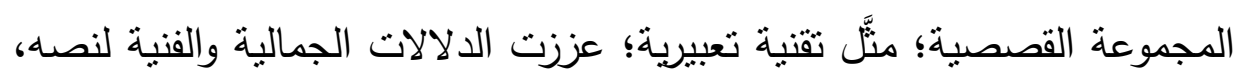

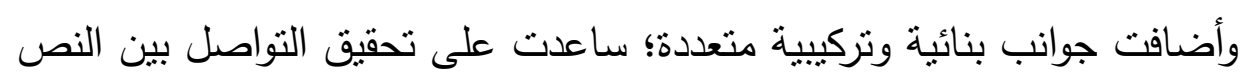

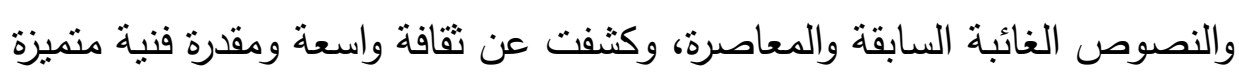
للمبدع، أكدت تفرده وتمبزه في مجاله. 


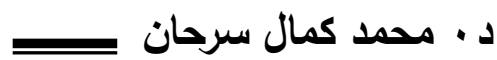

المصادر والمراجع

$$
\text { أولًا - المصادر: }
$$

ا-طه وادي: مجموعة "حكاية الليل والطريق"-مكتبة مصر -القاهرة-طץ-

$$
\text { ثانيًا - المراجع: }
$$

ا- أبو الطيب المتتبي: ديوان أبي الطيب المتتبي-صححه عبد الوهاب عزاملجنة التأليف والنشر -كت

Y- أبو عبد الرحمن محمد السلمي: طبقات الصوفية-دار الكتب العلمية-بيروتط. . r.

r- أبو محمد عبد الله بن مسلم: الإمامة والسياسة-مطبعة النيل-مصر -جr$.19 . \varepsilon$ ع- أبو نواس، الحسن بن هانئ: تحقيق أحمد عبد المجيد الغزالي-دار الكتاب العربي -بيروت-دت.

0- أحمد زكي صفوت: جمهرة خطب العرب في عصور العرب الزاهرة-المكتبة

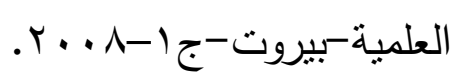

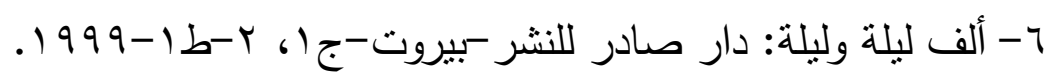

V- أمل أحمد عبد اللطيف أحمد: التتاص في رواية إلياس خوري باب الثمسماجستير - كلية الدراسات العليا-جامعة النجاح-0 . . r.

1- إنجيل متّى: الإصحاح الخامس -كنيسة الأنبا تكلا هيمانوت-الإسكندرية-دت. 9- إنجيل يوحنا: الإصحاح الثالث- كنيسة الثهيد مارجرجس-اسبورتتجد ت.

• ا-بديع الزمان الهذذاني: مقامات بديع الزمان الهمذاني-حققها محمد محى الدين عبد الحميد-الهيئة المصرية العامة للكتاب-r . . . . 
1ا-بيرم التونسي: بيرم والمقامات-جا ا-إثراف رشدي صالح-الهيئة المصرية العامة للكتاب-r . . r.

rا-تزفيتان تودوروف: الأدب والدلالة-ترجمة محمد نديم خشفة-مركز الإنماء

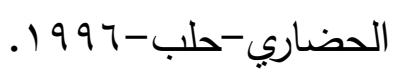

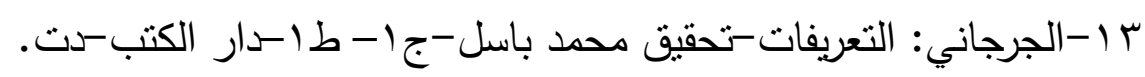
ـ ا-جوليا كريستقيا: علم النص-ترجمة فريد الزاهي -دار توبقال للنشر -الدار

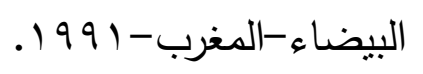

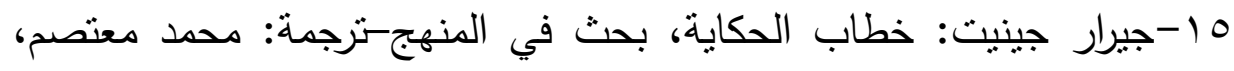

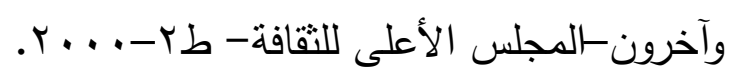

17-حسن محمد حماد: نداخل النصوص في الرواية العربية- الهيئة المصرية العامة للكتاب- د ت.

IV

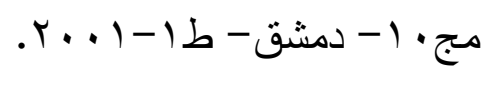

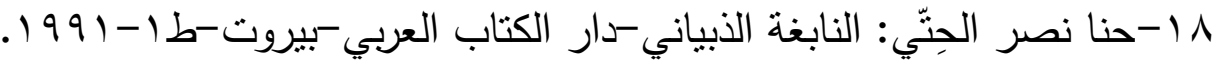
9 19-سارة بوجمعة: جماليات التناص في شعر محمد جربوعة-ماجستير -كلية

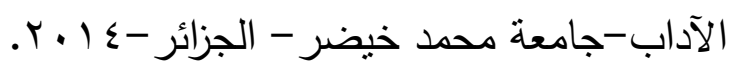

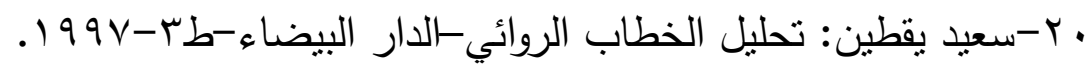

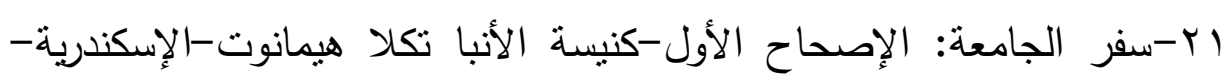
دت.

r Y-شاكر الحاج مخلف: بيرم التونسي، شاعر الغربة والثورة والحب-جريدة

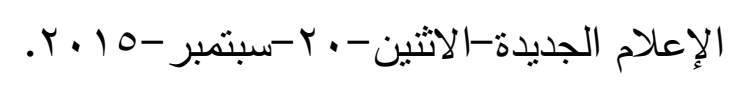

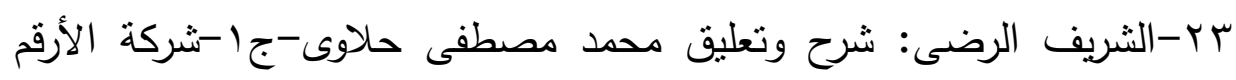

$$
\text { للنشر -بيروت-ط ا-1999 1. }
$$




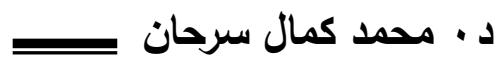

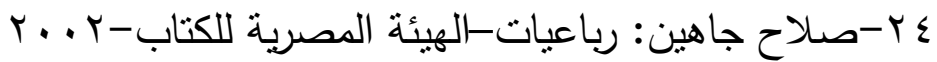

هץ-طه وادي: رواية "الكهف السحري"- مكتبة مصر -د ت.

ج -بهه وادي: مجموعة "الدموع لا تمسح الأحزان"-مكتبة مصر - 991 .

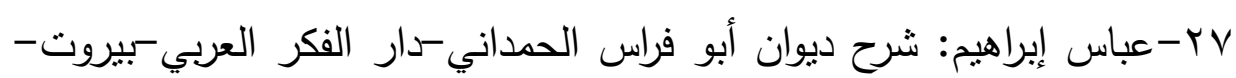

$.199 \leq$

^ץ-عبد الحليم محمود: قضية التصوف، المنقذ من الضال كدار المعارف-

$$
\text { r. . r. }
$$

qو-عبد الرحمن الأبنودي: مجموعة "مجموعة رسايل الأسطى حراجي لزوجته

فاطنة عبد الغفار "-الموسوعة العالمية للشعر العربي.

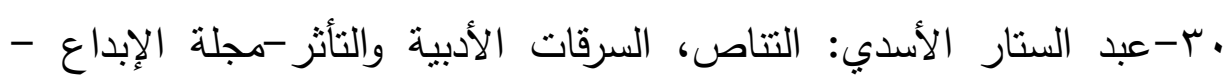

$$
\text { r }
$$

اب-عصام حفظ الله واصل: التتاص التراثي في الشعر المعاصر -دار غيداء

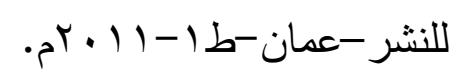

rr-علي عشري زايد: استذعاء الثخصيات التراثية في الثعر العربي المعاصر -

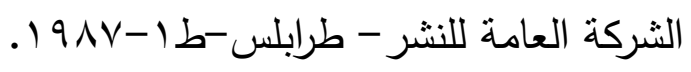

سب-فاروق جويدة: مجموعة الأعمال الكاملة-مركز الأهرام للترجمة والنشر -

$$
.19 \wedge v-1 b
$$

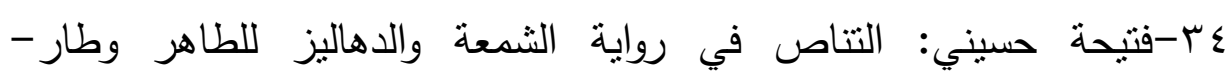

ماجستير - كلية الآداب- جامعة العقيد الحاج لخضر - الجزائر - r . . . .

هـ-كثير عزة: جمعه وشرحه إحسان عباس -دار التقافة-بيروت-دت.

بس-ماهر الثبال: منهج الإمام الغزالي في التصوف-مجلة البديل-الجمعة-

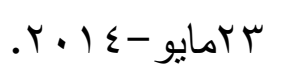

Vوستّى المسكين: المسيح، حياته، أعماله-مطبعة دير القديس أنبا مقار -وادي

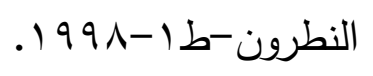


1ץ-محمد الثيخ: الحكمة العربية، دليل التراث العربي إلى العالمية-الثبكة

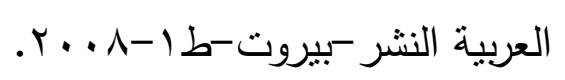

9ب-محمد بن عبد الرحمن المقرن: ديوان مليكة الطهر -دار القاسم للنشر -

$$
\text { السعودية-دت. }
$$

محمد عزام: النص الغائب، تجليات التتاص في الثعر العربي-منشورات

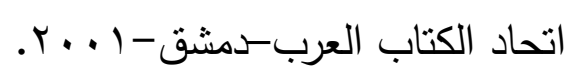

101-محمد نبيس: ظاهرة الثعر المعاصر في المغرب، مقاربة بنيوية تكوينية-دار

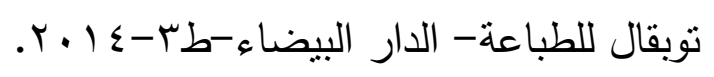

9-محمود الأحمدية: النظريات الثلاثة في علاقة الإنسان بالبيئة- الأنباء-

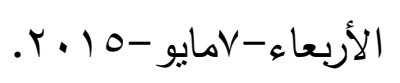

• צ-مشتاق عباس معن: شعرية التتاص، قراءة في شعرية كريستفيا السلبية،

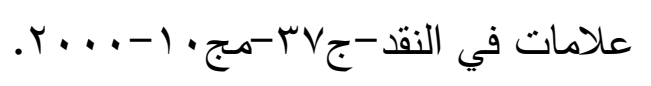

آ-مصطفى السعدني: التتاص الثعري، قراءة أخرى لقضية السرقات- منشأة

$$
\text { المعارف المصرية-1991. }
$$

با-منير محمد قميحة: الأخطل الصغير، حياته وشعره-دار الآفاق الجديدة-

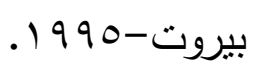

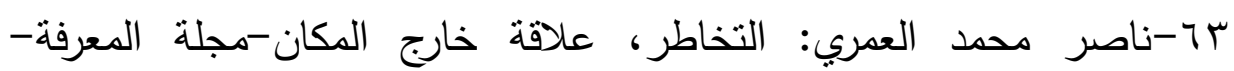

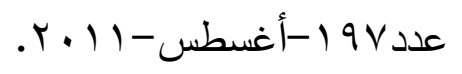

ع ا-نجيب سرور: مسرحية آه يا ليل يا قمر، مأساة شعرية-دار الكاتب العربي

$$
\text { للطباعة-القاهرة-1971 } 197 \text {. }
$$

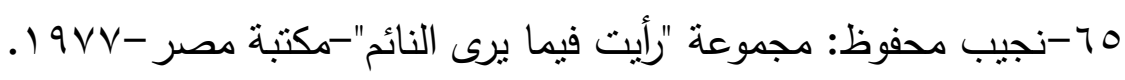
47-نزار عبشي: التتاص في شعر سليمان العيسي-ماجستير -كلية الآداب-

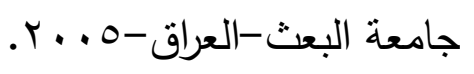




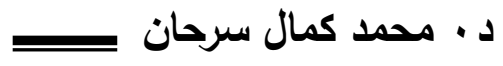

VT-نزيه مؤيد العظيم: رحلة في بلاد العربية السعيدة-دار التتوير للطباعة

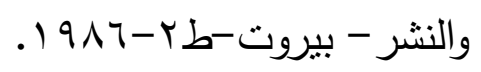

1 צ-نعيم قعر المثرد: استراتيجية التتاص في رواية سرادق الحلم والفجيعة لعز

الدين جلاوجي -ماجستير -كلية الآداب-جامعة قاصدي مرباح-الجزائر -

$$
\text { .r. . . }
$$

9 7-يمنى العيد: تقنيات السرد الروائي -دار الفارابي-بيروت-طب-r 99 1. 